Flávia Cristina Trevizan

\title{
CONHECIMENTOS FORTUITOS NO PROCESSO PENAL critérios de admissibilidade
}

\author{
DISSERTAÇÃO DE MESTRADO \\ Orientador: Prof. Dr. José Raul Gavião de Almeida
}

Faculdade de Direito

Universidade de São Paulo

São Paulo 
Flávia Cristina Trevizan

\section{CONHECIMENTOS FORTUITOS NO PROCESSO PENAL critérios de admissibilidade}

DISSERTAÇÃO DE MESTRADO

Orientador: Prof. Dr. José Raul Gavião de Almeida

Dissertação apresentada à Faculdade de Direito da Universidade de São Paulo como requisito parcial para obtenção do título de Mestre em Direito Processual Penal, sob a orientação do Prof. Dr. José Raul Gavião de Almeida.

Faculdade de Direito

Universidade de São Paulo

São Paulo 
Banca Examinadora: 


\section{AGRADECIMENTOS}

Ao Prof. Dr. José Raul Gavião de Almeida, pela diligente orientação e pela confiança.

Ao Prof. Dr. Gustavo Badaró e ao Prof. Dr. Marcos Alexandre Coelho Zilli, pelas valiosas contribuições ao desenvolvimento do presente trabalho na banca de qualificação.

Ao Prof. Titular Dr. Antonio Scarance Fernandes, por todo o aprendizado no curso de pósgraduação.

A Fernanda Rocha Loures, Anderson Lopes, Renato Vieira, Guilherme Madeira, Pedro Iokoi, Mariana Monteiro, Liliana Carrard, Gregório Edoardo e demais colegas de pósgraduação, com os quais compartilhei o entusiasmo pelas aulas ministradas durante o curso.

A Antonio Acir Breda, Juliano Breda, José Guilherme Breda e Maria Francisca Accioly, que recentemente me acolheram na sociedade do escritório Breda Advogados Associados.

A Beatriz Chagas, por garantir a retaguarda no escritório.

A Alaor Leite, pela amizade, apesar da distância, e pela imensa disposição em ler o trabalho.

A Suely e Saint-Clair, pelo incentivo.

A Alana, Juliana, Alessi, Adriana, Cristina e Larissa, pela amizade.

A meus pais Maria Júlia e Carlos, pelo amor e pelo apoio fundamental em todas as etapas que levaram à elaboração do trabalho.

A meu irmão Guilherme e minha cunhada Helen, pela torcida.

A Eduardo, por suportar minhas angústias. Sua compreensão e seu carinho me propiciaram o apoio emocional indispensável ao desenvolvimento do estudo. 


\section{RESUMO}

TREVIZAN, Flávia Cristina. Conhecimentos fortuitos no processo penal: critérios de admissibilidade. Dissertação (Mestrado) - Faculdade de Direito, Universidade de São Paulo, São Paulo, 2013.

O presente trabalho tem por objeto o estudo dos conhecimentos obtidos de forma fortuita, através da realização legal de um meio de obtenção de prova autorizado judicialmente, que não se reportam ao crime cuja investigação legitimou a medida restritiva. A fim de viabilizar essa abordagem foi necessário rever alguns conceitos relacionados à noção de prova no processo penal, que se colocam como pontos de partida para o enfrentamento do assunto. Na sequência, os conhecimentos fortuitos são inseridos no tema da obtenção da prova criminal, ligada à proteção da intimidade e da privacidade, tendo como foco principal a interceptação das comunicações telefônicas e a busca domiciliar. Para tanto, toma-se em consideração o princípio da especialidade da prova, que justifica que a limitação a direitos fundamentais esteja restrita e vinculada à apuração do crime que ensejou tal intervenção, motivo pelo qual o direito ao sigilo das comunicações e o direito à inviolabilidade da intimidade e do domicílio são analisados sob a perspectiva do panorama constitucional e legal brasileiro. A questão passa necessariamente pela análise do tema no Direito Comparado e pelo levantamento das diversas manifestações encontradas na doutrina e na jurisprudência nacional sobre a problemática, sobretudo em razão do silêncio legislativo quanto à solução jurídica da questão no ordenamento pátrio. Assim, após afastar as teses que defendem a negação absoluta dos conhecimentos fortuitos ou sua valoração sem restrições, conclui pela necessidade de se delimitar as fronteiras entre os conhecimentos imputados à própria investigação e aqueles que, inversamente, se levam em conta de conhecimentos fortuitos, socorrendo-se para tanto de um critério objetivo que concretize essa distinção. Isto porque, dela dependerá o tratamento a ser conferido aos conhecimentos obtidos em investigação de crime diverso, no que se refere à sua admissibilidade no processo e sua valoração pelo julgador como elemento de prova, apto à demonstração do delito casualmente descoberto, ou sua eventual utilização como mera notícia de crime formadora de indício. Por fim, são enfrentadas questões específicas suscitadas durante o desenvolvimento do estudo, e que colocam à prova o critério adotado.

Palavras-chave: Processo penal. Conhecimentos fortuitos. Encontro casual. Princípio da especialidade. Meios de obtenção de prova. Interceptação telefônica. Busca domiciliar. 


\begin{abstract}
TREVIZAN, Flávia Cristina. Fortuitous knowledge in criminal proceedings: admissibility criteria. Dissertation (Master's Degree) - Law School, Universidade de São Paulo, São Paulo, 2013.

The present paper has as its aim the study of knowledge obtained from fortuitous way through a legal means of obtaining evidence legally authorized, that does not relate to the crime which investigation legitimized the restraint measure. In order to make this approach it was necessary to review some concepts related to the notion of evidence in criminal proceedings, which arise as starting points for the confrontation of the subject. In the continuation, the fortuitous knowledge is inserted into the topic of obtaining criminal evidence, linked to the protection of privacy and intimacy, having as its main focus the interception of telephone communications and home search. To do so, it is taken into account the principle of specialty of evidence, which justifies that limiting the fundamental rights is restricted and tied to the investigation of the crime that resulted in such an intervention, which is why the right to confidentiality of communications and the right to inviolability of domicile and intimacy are analyzed from the perspective of constitutional and legal Brazilian panorama. The question goes necessarily through by examining the topic in Comparative Law and the survey of various manifestations found in doctrine and national case law on the issue, especially in view of the legislative silence as to the legal solution of the matter in land use. So, after removing the arguments defending the absolute denial of the fortuitous knowledge or its valuation without restrictions, it is concluded by the need to delimit the boundaries between imputed knowledge to the research itself and those that, conversely, are taken into account of fortuitous knowledge, helping to as much of an objective criterion that achieves this distinction. This is because from it will depend the treatment to be given to information obtained in the investigation of crime, as regards its admissibility in the process and its valuation by the Court as evidence to the demonstration of the offense or its possible use discovered fortuitously as mere forming crime news clue. Finally, specific issues are faced raised during the development of the study, and that put to the test the adopted criterion.
\end{abstract}

Keywords: Criminal proceedings. Fortuitous knowledge. Chance encounter. The principle of specialty. Means of obtaining evidence. Telephone interception. Home search. 


\section{SUMÁRIO}

INTRODUÇÃO....

PRIMEIRA PARTE: PONTOS DE PARTIDA PARA ABORDAGEM DOS

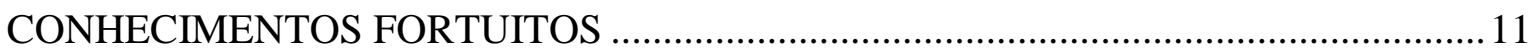

1. NOÇÕES GERAIS SOBRE A PROVA NO PROCESSO PENAL ............................. 12

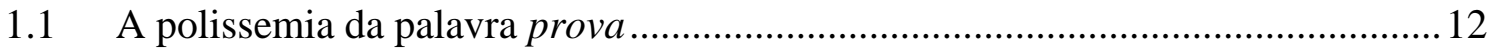

1.2 Provas ilícitas e provas ilegítimas: necessária distinção ..................................... 14

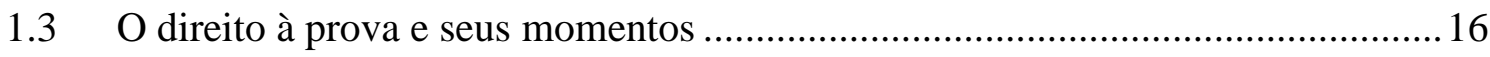

1.4 Inadmissibilidade das provas obtidas por meios ilícitos e consequência da sua

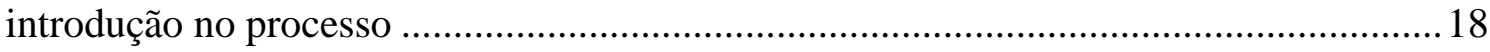

2. A INSERÇÃO DOS CONHECIMENTOS FORTUITOS NO TEMA DA

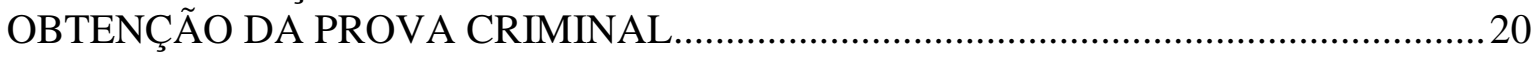

2.1 Conhecimentos fortuitos: em torno de um conceito e delimitação ....................... 21

2.2 Conhecimentos fortuitos e inviolabilidades constitucionais em jogo .................... 25

2.3 Princípio da especialidade: o problema do desvio da vinculação causal nos

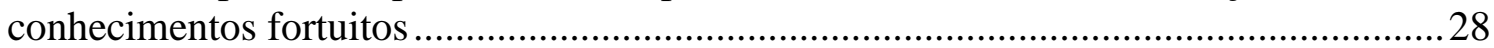

3. OS CONHECIMENTOS FORTUITOS NO ÂMBITO DOS MEIOS DE OBTENÇÃO

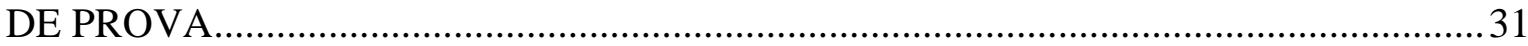

3.1 Interceptação das comunicações telefônicas ........................................................ 31

3.1.1 Sigilo das comunicações telefônicas e inviolabilidade da intimidade ............ 31

3.1.2 Interceptação telefônica e seus requisitos: a Lei 9.296/1996..........................33

3.1.3 Os conhecimentos fortuitos nas interceptações telefônicas ............................ 38

3.1.3.1 Interceptação e conhecimento fortuito de fato diverso........................... 40

3.1.3.2 Interceptação indicando outra pessoa que não a investigada e contra quem fora concedida a autorização.................................................................. 41

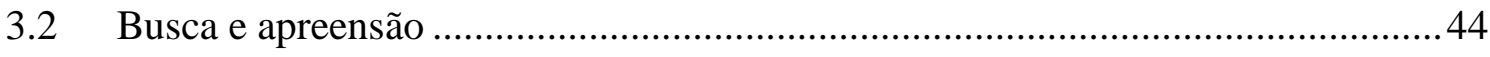

3.2.1 Inviolabilidade domiciliar e busca e apreensão ............................................. 44

3.2.2 Busca domiciliar: requisitos do mandado e condições de validade da

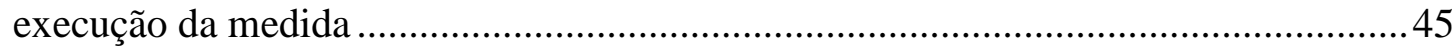

3.2.3 Os conhecimentos fortuitos no cumprimento dos mandados de busca e

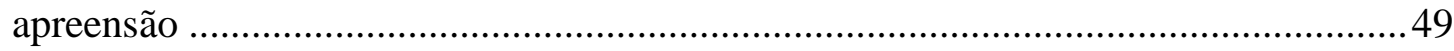

3.3 Um parêntese: outros meios de obtenção de prova (a criminalidade organizada)... 
SEGUNDA PARTE: EM BUSCA DE UM CRITÉRIO SUSCETÍVEL DE DETERMINAR O ÂMBITO DE ADMISSIBILIDADE DOS CONHECIMENTOS FORTUITOS

4. O TRATAMENTO DOS CONHECIMENTOS FORTUITOS NO DIREITO PROCESSUAL PENAL ESTRANGEIRO: ALEMANHA, PORTUGAL, ITÁLIA E

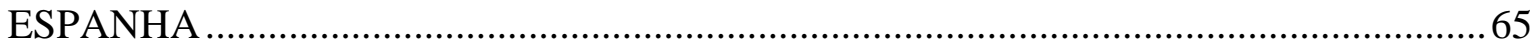

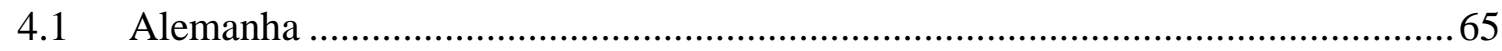

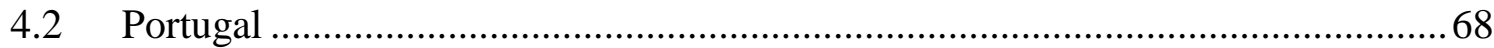

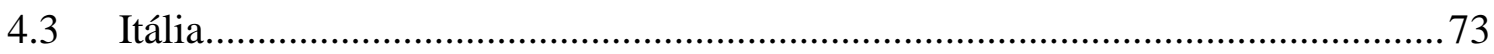

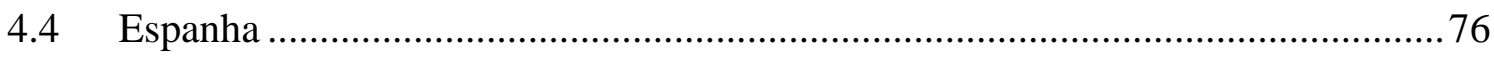

5. O TRATAMENTO DOS CONHECIMENTOS FORTUITOS NO DIREITO

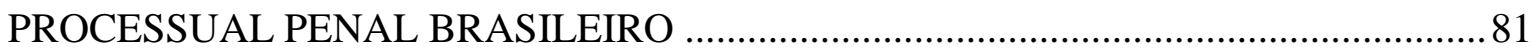

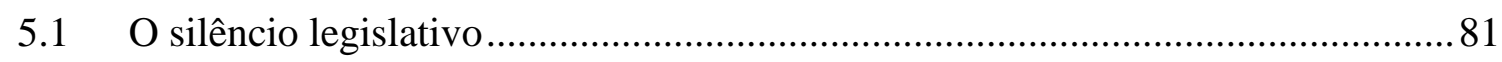

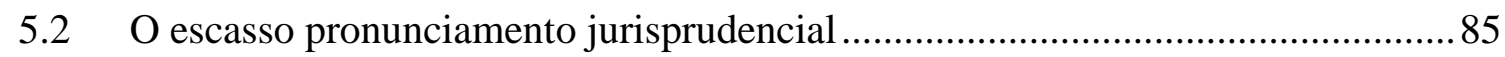

6. ANÁLISE DOS CONHECIMENTOS OBTIDOS EM INVESTIGAÇÃO POR

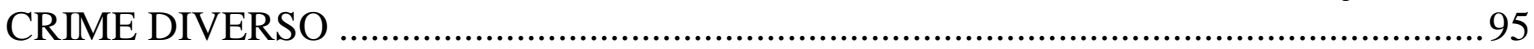

6.1 Negação absoluta dos conhecimentos fortuitos ou sua valoração sem

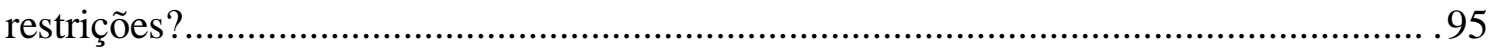

6.2 Critério adotado: âmbito de admissibilidade dos conhecimentos obtidos em

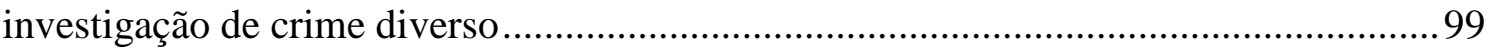

6.2.1 A admissibilidade dos conhecimentos fortuitos a partir do critério de definiç̧ão da competência por conexão e continência................................................... 100

6.2.2 A fronteira entre conhecimentos fortuitos e conhecimentos da

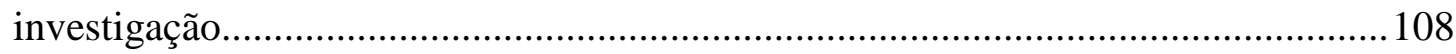

6.2.3 Valor dos conhecimentos fortuitos em decorrência do critério adotado......110

7. BREVE CASUÍSTICA DOS CONHECIMENTOS FORTUITOS

7.1 Conhecimento fortuito de crime permanente: a situação de flagrância nas buscas e apreensões .

7.2 Conhecimento fortuito de crime punido com detenção obtido em interceptação telefônica

7.3 Conhecimento fortuito de crime de competência material de juízo diverso e conhecimento da participação no delito de alguém que detenha prerrogativa de foro em virtude de suas funções 


\section{INTRODUÇÃO}

O presente trabalho tem por objeto o estudo dos conhecimentos obtidos de forma fortuita, no curso da realização legal de um meio de obtenção de prova autorizado judicialmente, que não se reportam ao crime objeto de investigação e legitimador da medida restritiva.

O tema demanda apreciação cuidadosa, porquanto põe em evidência a questão sempre conflituosa entre o respeito aos direitos fundamentais e o interesse na investigação e elucidação de fatos criminosos. Por isso, o presente estudo encontra-se dividido em duas partes.

A PRIMEIRA PARTE destina-se a fixar as bases que circundam os conhecimentos fortuitos, vertendo o tema a alguns conceitos que, na sua dimensão, atuam como pontos de partida e suporte para um ensaio de resposta à problemática, já que atrelada à obtenção de provas através de um meio ofensivo a direitos fundamentais consagrados constitucionalmente.

Assim, o Capítulo 1 traz para o trabalho alguns conceitos atinentes à atividade probatória, para se estabelecer um referencial à aparição da figura dos conhecimentos fortuitos no processo penal. Afinal, quando se promove o estudo da prova, a questão terminológica deve ser sempre delimitada.

Na sequência, no Capítulo 2, como a inserção do problema dos conhecimentos fortuitos no tema da obtenção da prova criminal não pode ser tratada senão de uma perspectiva constitucional, ligada à proteção da intimidade e da privacidade, além de se tentar delimitá-lo, o faz considerando o princípio da especialidade da prova, que justifica que a autorização extrema de limitação a direitos fundamentais esteja restrita à apuração do crime que ensejou a decisão judicial.

E o Capítulo 3 traz as variáveis que podem incidir no que se refere ao encontro casual de informações, dada as particularidades normativas do regime processual penal dos diversos meios de obtenção de prova, aproximando-os do tema dos conhecimentos fortuitos. Na verdade, assume-se desde já um corte epistemológico (que reflete uma escolha pessoal) do trabalho: o estudo dos conhecimentos fortuitos não passa pela análise de todos os meios de obtenção de prova, tendo seus olhos voltados à interceptação 
telefônica e à busca domiciliar. Isso não significa que a figura dos conhecimentos fortuitos no processo penal esteja atrelada à obtenção de provas somente através desses meios de investigação, mas a deficiente regulação da matéria envolvendo outros meios impede que se estabeleçam claramente os parâmetros limitativos de sua licitude probatória, essencial para a análise da problemática de que trata o presente trabalho.

Na SEGUNDA PARTE, busca-se um critério suscetível de determinar o âmbito de admissibilidade dos conhecimentos fortuitos.

Para tanto, contando com as contribuições da doutrina estrangeira para a solução do problema proposto, o Capítulo 4 contextualiza a abordagem do tema no direito processual penal alemão, português, italiano e espanhol.

E ao tempo em que se lamenta, no Capítulo 5, a omissão legislativa nacional sobre a problemática, faz-se uma breve análise dos textos que tramitam ou tramitaram no Poder Legislativo, sem descuidar do necessário, embora breve (até porque escasso), tratamento então conferido aos conhecimentos fortuitos nos tribunais pátrios.

Só a partir daí é possível defender, no Capítulo 6, um critério balizador para o aproveitamento dos conhecimentos obtidos em investigação de crime diverso, compatível com o sistema processual penal brasileiro.

Por fim, no Capítulo 7, algumas questões específicas, ancoradas durante o desenvolvimento do estudo, são provocadas e enfrentadas. 
PRIMEIRA PARTE: PONTOS DE PARTIDA PARA ABORDAGEM DOS CONHECIMENTOS FORTUITOS 


\section{NOÇÕES GERAIS SOBRE A PROVA NO PROCESSO PENAL}

Inicialmente, é necessário trazer para o trabalho alguns conceitos atinentes à prova, para se estabelecer um referencial à aparição da figura dos conhecimentos fortuitos no processo penal, sobretudo para o ulterior desenvolvimento de alguns critérios de sua admissibilidade, já que atrelada à obtenção de provas através de um meio ofensivo a direitos fundamentais consagrados constitucionalmente.

Assim, cumpre fixar as bases que circundam os conhecimentos fortuitos, vertendo o tema a alguns conceitos que, na sua dimensão, atuam como pontos de partida e suporte para um ensaio de resposta à problemática dessa figura no processo penal.

\subsection{A polissemia da palavra prova}

O termo prova, tanto na linguagem comum, filosófica ou científica, como na terminologia jurídica, é sabidamente polissêmico, “designando aspectos diversos do vasto campo de operações do intelecto na busca e na comunicação do conhecimento verdadeiro". ${ }^{2}$ Daí a necessidade de "se estabelecer, do modo mais preciso possível, o significado atribuído à expressão prova nas variadas situações em que é empregada no discurso jurídico".2 O Vocabulário Jurídico DE PLÁCIDO E SILVA define prova nos seguintes termos:

Do latim proba, de probare (demonstrar, recohecer, formar juízo de), entende-se, assim, no sentido jurídico, a denominação, que se faz, pelos meios legais, da existência ou veracidade de um fato material ou de um ato jurídico, em virtude da qual se conclui por sua existência do fato ou ato demonstrado. A prova consiste, pois, na demonstração da existência ou da veracidade daquilo que se alega como fundamento do direito que se defende ou que se contesta. ${ }^{3}$

\footnotetext{
${ }^{1}$ GOMES FILHO, Antonio Magalhães; BADARÓ, Gustavo Henrique Righi Ivahy. Prova e sucedâneos de prova no processo penal brasileiro. In: Revista Brasileira de Ciências Criminais, São Paulo, $\mathrm{n}^{\circ}$ 65, p.175208, mar-abril/2007. p.177.

${ }^{2}$ Ibid., p.177.

${ }^{3}$ Prova. In: Vocabulário Jurídico. 15.ed. Rio de Janeiro: Forense, 1998. p.656.
} 
De fato, por um lado, a expressão prova constitui, ao menos em uma primeira aproximação, consoante AdA Pelegrini GrinOver, SCARANCE Fernandes e MAGALhães GOMES FILHO, “o instrumento por meio do qual se forma a convicção do juiz a respeito da ocorrência ou inocorrência de certos fatos". ${ }^{4}$ Por isso, o tema da prova é o foco central da ciência processual, na medida em que é ela que vai formar o convencimento do julgador acerca dos fatos postos para julgamento, especialmente no campo do processo penal, orientado pelo princípio constitucional da presunção de inocência, segundo o qual a condenação do acusado deve estar amparada por provas seguras da culpabilidade.

Mesmo na terminologia processual, o termo prova é empregado com variadas significações, e só com estas premissas definidas é que se poderá dar atenção ao tema de que cuida o presente trabalho, ainda que, escusado será dizer, não se possa evitar a polissemia da palavra, de modo que o seu uso nos diferentes contextos há de esclarecer finalmente o sentido em que se toma a prova.

Magalhães Gomes FilHo, no artigo Notas sobre a terminologia da prova, enfrentou a natureza polissêmica do vocábulo, que pode servir para indicar cada um dos dados objetivos que confirmam ou negam uma asserção a respeito de um fato (elemento de prova) ou pode designar as pessoas ou coisas das quais se pode conseguir o elemento de prova (fonte de prova). Assim, é fonte de prova tudo aquilo que é idôneo a fornecer resultados relevantes para a decisão do juiz (por exemplo, uma pessoa ou um documento), e elemento de prova é o que se extrai da fonte de prova. ${ }^{5}$

O meio de introdução destes elementos de prova, isto é, o canal comunicativo pelo qual eles entram, se admitidos, no processo, é chamado meio de prova (ou meio de produção de prova). Nas palavras de MAGALHÃEs GOMES FILHO, meios de prova são “os instrumentos ou atividades por intermédio dos quais os dados probatórios (elementos de prova) são introduzidos e fixados no processo". 6 Desse modo, os meios de prova caracterizam-se pela sua aptidão para serem, por si próprios, fonte de convencimento, motivo pelo qual devem viabilizar o contraditório: "os meios de prova referem-se a uma atividade endoprocessual que se desenvolve perante o juiz, com o conhecimento e

\footnotetext{
${ }^{4}$ As nulidades no processo penal. 11.ed. São Paulo: Revista dos Tribunais, 2009. p. 112.

${ }^{5}$ Notas sobre a terminologia da prova (reflexos no processo penal brasileiro). In: YARSHELL, Flávio Luiz; MORAES, Maurício Zanoide de (Org.). Estudos em homenagem à Professora Ada Pellegrini Grinover. São Paulo: DPJ Editora, 2005. p.307-308.

${ }^{6}$ Ibid., p.308.
} 
participação das partes, visando a introdução e a fixação de dados probatórios no processo". 7

Já os meios de obtenção de prova (ou meios de investigação de prova, ou meios de pesquisa de prova) podem ser definidos, agora nas palavras de GERMANO MARQUES DA SILVA, como "instrumentos de que se servem as autoridades judiciárias para investigar e recolher meios de prova; não são instrumentos de demonstração do thema probandi, são instrumentos para recolher no processo esses meios". ${ }^{8}$ Por isso, prevalecem na fase préprocessual, identificada pela necessidade de, por eles, buscar (pesquisar, descobrir) alguma fonte de prova, através da qual se possa conseguir um elemento de prova a ser introduzido no processo. Daí porque o fator surpresa do envolvido permeia os meios de obtenção de prova, como por exemplo, a busca e apreensão e a interceptação das comunicações telefônicas.

Esta distinção é de extrema relevância no campo do direito probatório, como destaca Magalhães Gomes Filho, no sentido de que, na prática, essa diversidade terminológica serve para identificar as possíveis repercussões das irregularidades verificadas em relação aos meios de prova e aos meios de obtenção de prova: "No primeiro caso, a consequência do vício será a nulidade da prova produzida (rectius, dos elementos de prova), enquanto no segundo tratar-se-á de prova inadmissível no processo, diante da violação de regras relacionadas à sua obtenção (art.5º, LVI, da CF)". 9

\subsection{Provas ilícitas e provas ilegítimas: necessária distinção}

Adotando-se, assim como a maioria da doutrina brasileira, a terminologia proposta por PIETRo Nuvolone, conforme estudo referido por ADA PELLEGRINI GRINOVER na obra Liberdades públicas e processo penal, e tomando-se como ponto de partida o conceito amplo de prova proibida (ou vedada), tem-se na expressão prova ilegal o gênero que compreende as espécies prova ilícita e prova ilegítima. Transcreve-se a lição da autora sobre a importante diferenciação terminológica:

\footnotetext{
${ }^{7}$ Ibid., p.309.

${ }^{8}$ Curso de Processo Penal. v. II. 2.ed. Verbo, 1999. p.189.

${ }^{9}$ Notas sobre a terminologia... op.cit., p. 310.
} 


\begin{abstract}
A tônica de Nuvolone, no campo das proibições da prova, é dada pela natureza processual ou substancial da vedação: a proibição tem natureza exclusivamente processual quando for colocada em função de interesses atinentes à lógica e à finalidade do processo; tem, pelo contrário, natureza substancial quando, embora servindo imediatamente também a interesses processuais, é colocada essencialmente em função dos direitos que o ordenamento reconhece aos indivíduos, independentemente do processo. $^{10}$
\end{abstract}

Em síntese, na prova ilegítima, a proibição tem natureza exclusivamente processual: é aquela produzida violando-se normas de direito processual. Do ponto de vista material, a prova ilícita é aquela "colhida infringindo-se normas ou princípios colocados pela Constituição e pelas leis, frequentemente para a proteção das liberdades públicas e dos direitos da personalidade e daquela sua manifestação que é o direito à intimidade". ${ }^{11}$ Assim, constituem prova ilícita, por exemplo, as obtidas com violação do domicílio (CF, art. $5^{\circ}$, inc. XI) ou das comunicações telefônicas (CF, art. $5^{\circ}$, inc. XII).

Para manter a coerência com a distinção terminológica destacada no item anterior, pertinente esclarecer e enfatizar que "quando a proibição for colocada por uma lei processual, a prova (rectius, o meio de prova) será ilegítima (ou ilegalmente produzida); quando, pelo contrário, a proibição for de natureza material, a prova será ilícita (rectius: a fonte de prova será ilicitamente colhida)". ${ }^{12}$

Como destaca TORQuATO Avolio, a par da distinção no plano da natureza da norma violada, outra se faz quanto ao momento da transgressão: enquanto na prova ilegítima a ilegalidade ocorre no momento de seu ingresso ou de sua produção no processo,

\footnotetext{
${ }^{10}$ Liberdades públicas e processo penal: as interceptações telefônicas. São Paulo: Saraiva, 1976. p.126-127.

${ }^{11}$ Ibid., p.129. O conceito é adotado pela autora ADA PELLEGRINI GRINOVER até os dias atuais, inclusive em obra coletiva (GRINOVER; FERNANDES; GOMES FILHO, As nulidades... op.cit., p.125).

Não se ignora que a Lei 11.690/2008, que introduziu substanciais alterações no Código de Processo Penal de 1941, especialmente em relação à disciplina da prova, forneceu no caput do novel artigo 157 uma definição do que se deve entender por provas ilícitas: "as obtidas em violação a normas constitucionais ou legais". Mas, concorda-se com a melhor doutrina, de que essa definição legal de prova ilícita não representa a melhor opção do legislador nacional, "que pode levar a equívocos e confusões, fazendo crer, por exemplo, que a violação de regras processuais implica ilicitude da prova (...)" (GOMES FILHO, Antonio Magalhães. Provas - Lei 11.690, de 09.06.2008. In: MOURA, Maria Thereza Rocha de Assis (Coord.). As Reformas no Processo Penal: as novas leis de 2008 e os projetos de reforma. São Paulo: Revista dos Tribunais, 2008. p.266). Ainda nesse sentido: "A reforma processual acabou por apresentar novo conteúdo para o conceito de prova ilícita no artigo 157 (...). Porém, cumpre observar que se revela perigosa a redação apresentada pelo artigo 157, na medida em que já estava relativamente assentado na doutrina e na jurisprudência o conceito de prova ilícita e sua diferenciação com a prova ilegítima. Tal equívoco de redação no referido artigo acaba por causar confusão (...)". (DEZEM, Guilherme Madeira. Da prova penal: tipo processual, provas típicas e atípicas. Campinas: Millennium, 2008. p.124).

${ }^{12}$ GOMES FILHO; BADARÓ, Prova e sucedâneos... op.cit., p.198.
} 
a prova ilícita pressupõe uma violação no momento da obtenção da prova, "anterior ou concomitantemente ao processo, mas sempre externamente a este". ${ }^{13}$

A distinção é necessária uma vez que diversos são os efeitos. Enquanto a violação a regras processuais (prova ilegítima) leva à nulidade do ato de formação da prova e impõe sua renovação, a prova obtida com violação de lei material (prova ilícita) implica ilicitude da prova e, em consequência, a inadmissibilidade de seu entranhamento aos autos do processo.

A relevância para fins do presente trabalho está no enfoque a ser dado, não ao momento de introdução da prova no processo, mas em momento anterior, vale dizer, no momento da obtenção da prova, do seu surgimento no plano fático.

\section{3 direito à prova e seus momentos}

O direito à prova está relacionado aos direitos de ação e defesa, justamente porque a concretização destes depende da possibilidade de produção probatória, oportunizando-se às partes interferir ativamente sobre o desenvolvimento e o resultado do processo.

De fato, “o concreto exercício da ação e da defesa fica essencialmente subordinado à efetiva possibilidade de se representar ao juiz a realidade do fato posto como fundamento das pretensões das partes, ou seja, de estas poderem servir-se de provas". ${ }^{14}$

Aliás, o direito à prova também deve ser reconhecido antes ou fora do processo, até como meio de se obter elementos que autorizem a persecução (ou possam evitá-la), constatação esta que permite identificar um “direito à investigação, pois a faculdade de procurar e descobrir provas é condição indispensável para que se possa exercer o direito à prova". 15

Ao tratar das atividades processuais concernentes à prova, ADA PELEGRINI Grinover, Scarance Fernandes e Magalhães Gomes Filho desdobram o direito à

\footnotetext{
${ }^{13}$ Provas ilícitas: interceptações telefônicas, ambientais e gravações clandestinas. 4.ed. São Paulo: Revista dos Tribunais, 2010. p.51.

${ }_{15}^{14}$ GRINOVER; FERNANDES; GOMES FILHO, As nulidades... op.cit., p.113-114.

15 GOMES FILHO, Antonio Magalhães. Direito à Prova no Processo Penal. São Paulo: Revista dos Tribunais, 1997. p.86.
} 
prova em quatro momentos: (1) proposição - direito de requerer a produção da prova; (2) admissão - direito a que o juiz decida sobre esse pedido e se manifeste sobre a sua admissibilidade; (3) produção - direito à introdução no processo da prova requerida e admitida, em contraditório e na presença do juiz; e (4) apreciação - direito a que a prova introduzida seja objeto de valoração pelo julgador. ${ }^{16}$

Sendo certo que o exercício do direito à prova se estende a todos esses momentos, com razão afirma PAOLO TONINI que "o 'direito à prova' é uma expressão sintética que compreende o direito de todas as partes de buscar as fontes de prova, requerer a admissão do respectivo meio, participar de sua produção e apresentar uma valoração no momento das conclusões". ${ }^{17}$

Mas o direito à prova não é absoluto, e encontra limites na encruzilhada entre a busca da verdade e o respeito a direitos fundamentais. De fato, "como qualquer direito, também está sujeito a limitações decorrentes da tutela que o ordenamento confere a outros valores e interesses igualmente dignos de proteção". ${ }^{18}$ Forte nesse sentido é a disposição que regulando a atividade do processo penal inadmite "as provas obtidas por meios ilícitos" (CF, art. 5\%, LVI $)^{19}$.

$\mathrm{Na}$ verdade, pode-se afirmar que a consequência do direito à prova - ou o seu reverso - é o direito à exclusão das provas obtidas ilicitamente. Essa "proibição de utilização de prova obtida por meio ilícito no processo é uma regra posta a serviço do princípio que declara as diversas espécies de inviolabilidades previstas no art. $5^{\circ}$ da Constituição (...)".20

Nessa ordem de considerações é que AlEXANDRE DE MoRAES afirma que "a inadmissibilidade das provas ilícitas no processo deriva da posição preferente dos direitos fundamentais no ordenamento jurídico, tornando impossível a violação de uma liberdade pública para obtenção de qualquer prova". ${ }^{21}$

\footnotetext{
${ }^{16}$ As nulidades... op.cit., p.126.

${ }^{17}$ A prova no processo penal italiano. Tradução de Alexandra Martins e Daniela Mróz. São Paulo: Revista dos Tribunais, 2002. p.83.

${ }^{18}$ GOMES FILHO, Direito à Prova... op.cit., p.91.

${ }^{19}$ Nos termos do art.5 ${ }^{\circ}$ LVI, da CF, "são inadmissíveis, no processo, as provas obtidas por meios ilícitos", vedação esta reproduzida no artigo 157, caput, do CPP, com a redação que lhe deu a Lei 11.690/2008.

${ }^{20}$ CARVALHO, Luis Gustavo Grandinetti Castanho de. Processo Penal e (em face da) Constituição. 3.ed. Rio de Janeiro: Lumens Juris, 2004. p.97.

${ }^{21}$ Direitos humanos fundamentais: teoria geral, comentários aos arts. $1^{\circ}$ a $5^{\circ}$ da Constituição da República Federativa do Brasil, doutrina e jurisprudência. São Paulo: Atlas, 1998. p.257.
} 


\subsection{Inadmissibilidade das provas obtidas por meios ilícitos e consequência da sua introdução no processo}

Nosso ordenamento jurídico adotou o sistema da inadmissibilidade das provas obtidas por meios ilícitos, conforme o disposto no artigo $5^{\circ}$, LVI, da Constituição Federal $^{22}$. Como registra GUSTAVO BADARÓ, a inadmissibilidade é uma sanção processual, para uma violação de uma regra material. ${ }^{23}$

Aliás, configura importante garantia em relação à ação persecutória do Estado, que resulta de uma

(...) ponderação já feita pelo constituinte: entre as inviolabilidades prescritas pela Constituição, de um lado, e eventualmente a segurança pública (e a verdade processual), de outro, o constituinte sobrevalorizou a primeira, em detrimento da segunda. Mais precisamente, entre a intimidade (e os demais bens protegidos pelos incisos X, XI e XII, do artigo $5^{\circ}$, da Constituição) e chegar-se o mais próximo possível da verdade do processo, prevaleceu a proteção daqueles bens. ${ }^{24}$

E diante da clareza do nosso texto constitucional, a consequência do reconhecimento da ilicitude na obtenção da prova é sua inadmissibilidade, ou seja, toda e qualquer prova nessa situação não poderia, em tese, sequer, ingressar nos autos.

A Constituição preocupa-se, segundo AdA PELLEGRINI GRINOVER, com o momento da admissibilidade, pretendendo claramente impedir os momentos sucessivos, de introdução e valoração da prova ilícita. ${ }^{25}$

Entretanto, se, apesar disso, os dados ingressarem no processo, não poderão ser valorados pelo juiz, ou seja, não podem ser tomados como fundamento por nenhuma decisão judicial.

Destarte, o tema das provas ilícitas diz respeito à constatação do ato ilícito praticado na obtenção da prova (momento da operação por meio da qual a prova é obtida),

\footnotetext{
${ }^{22}$ Desde logo, um esclarecimento: as provas obtidas por meio ilícitos, consideradas inadmissíveis pelo inciso LVI do artigo $5^{\circ}$ da Constituição Federal, enquadram-se, tecnicamente, segundo postura aqui adotada, na categoria da prova cuja obtenção constitui ato materialmente ilícito, segundo a terminologia já referida no ITEM 1.2.

${ }^{23}$ Direito Processual Penal. Tomo I. Rio de Janeiro: Elsevier, 2008. p.206.

${ }^{24}$ CARVALHO, Processo Penal... op.cit., p.97-98.

${ }^{25} \mathrm{O}$ sistema de nulidades processuais e a Constituição. In: TUBENCHLAK, James; BUSTAMANTE, Ricardo (Org.). Livro de Estudos Jurídicos. v.6. Rio de Janeiro: Instituto de Estudos Jurídicos, 1993. p.168.
} 
sua consequente inadmissibilidade no processo (impossibilidade de ser utilizada processualmente) e, na hipótese de seu ingresso no processo, apesar da proibição, sua total ineficácia (proibição de valoração).

Mas foi só com a Lei 11.690/2008, que conferiu nova redação aos artigos do Código de Processo Penal relativos à prova, dentre os quais o artigo 157, que a nível infraconstitucional, além da reprodução da vedação da admissibilidade, no processo, das provas obtidas por meios ilícitos, se previu expressamente a consequência do ingresso da prova ilícita no processo, verbis: "São inadmissíveis, devendo ser desentranhadas do processo, as provas ilícitas (...)”.

Sacramentou assim o legislador ordinário a posição doutrinária e jurisprudencial de que a prova ilicitamente obtida deve ser considerada como inexistente e totalmente ineficaz $^{26}$, "retroagindo a sua ineficácia ao momento de seu nascedouro" ${ }^{27}$, motivo pelo qual deve ser desentranhada do processo e, o mais importante é que, de qualquer modo, não pode ser valorada pelo juiz.

\footnotetext{
26 “Trata-se de não-ato, de não-prova, que as reconduz à categoria da inexistência jurídica. Elas simplesmente não existem como provas: não tem aptidão para surgirem como provas. (...) Daí sua total ineficácia" (GRINOVER; FERNANDES; GOMES FILHO, As nulidades... op.cit., p.136). Perante o Supremo Tribunal Federal, no julgamento da AP 307, o Ministro CELSO DE MELLo destacou em trecho de seu voto: "A prova ilícita é prova inidônea. Mais do que isso, prova ilícita é prova imprestável. Não se reveste, por essa explícita razão, de qualquer aptidão jurídico-material. Prova ilícita, sendo providência instrutória eivada de inconstitucionalidade, apresenta-se destituída de qualquer grau, por mínimo que seja, de eficácia jurídica". (BRASIL. Supremo Tribunal Federal. Plenário. Ação Penal 307-3/DF. Relator Ministro Ilmar Galvão. Julgado em 13/12/1994. DJ 13/10/1995, p.34247. Acórdão disponível em: $\langle$ http://redir.stf.jus.br/paginadorpub/paginador.jsp?docTP=AC\&docID=324295 >. Acesso em: 09/07/2011).

${ }^{27}$ AVOLIO, Provas ilícitas... op.cit., p.109.
} 


\section{A INSERÇÃO DOS CONHECIMENTOS FORTUITOS NO TEMA DA OBTENÇÃO DA PROVA CRIMINAL}

A regra da inadmissibilidade das provas ilícitas passa pela análise do âmbito de obtenção da prova na perspectiva do mito da reconstrução da verdade no Processo Penal. De fato, a ação persecutória do Estado, para revestir-se de legitimidade, depende da forma como as provas são obtidas e trazidas ao processo, já que da explícita proscrição da prova ilícita $\left(\mathrm{CF}\right.$, art. $\left.5^{\circ}, \mathrm{LVI}\right)$, resulta a prevalência da garantia nela estabelecida sobre o interesse na busca, a qualquer custo, da verdade no processo.

Uma das vertentes do tema é o estudo dos conhecimentos fortuitos, que são as informações obtidas de forma inusitada através da realização legal de um meio de obtenção de prova autorizado judicialmente, que não se reportam ao crime cuja investigação legitimou a medida restritiva. Considerando inclusive a criminalidade de forma organizada na atualidade, não é estranho admitir que fatos criminosos, diversos dos indicados pelo juiz na decisão que autorizou a medida excepcional, sejam descobertos, até mesmo envolvendo terceiras pessoas não indicadas e qualificadas e indivíduos que poderiam nem ser objeto da investigação. Neste contexto, é razoável se admitir que a investigação surpreenda.

O problema que se coloca está na (i)licitude destas provas oriundas de investigação por crime diverso e sua (in)admissibilidade no processo, no que se refere à inobservância da necessária vinculação causal que a prova deve guardar quando se está diante de uma medida que restringe direitos fundamentais, tais como a busca e apreensão e a interceptação das comunicações telefônicas, carecendo a questão de regulamentação legal no ordenamento brasileiro.

Afinal, os elementos recolhidos por um destes meios de obtenção, voltados a uma determinada investigação, podem ser admitidos no processo e valorados pelo julgador como prova bastante dos fatos encontrados fortuitamente, desvinculados do fato objeto de investigação legitimador da medida restritiva?

O tema demanda apreciação cuidadosa, porquanto põe em evidência a questão sempre conflituosa entre o respeito aos direitos fundamentais e o interesse na investigação e elucidação de fatos criminosos, de forma a obter o devido processo penal eficiente e obediente aos ditames do garantismo. Aliás, como adverte SCARANCE FERnANDES, “em 
uma visão moderna, esses dois vetores não se opõem, pois não se concebe um processo eficiente sem garantismo". ${ }^{28}$

Por isso, além de se tentar delimitar o que se compreende pela expressão conhecimentos fortuitos e qual o seu alcance, para se ensaiar um início de resposta à problemática do tema, é indispensável discorrer acerca de algumas garantias constitucionais, que de forma direta ou indireta, estão relacionadas com a sua figura.

\subsection{Conhecimentos fortuitos: em torno de um conceito e delimitação}

Desde já, cumpre destacar que o tema dos conhecimentos fortuitos pressupõe a obtenção de provas "sin existir lesión constitucional congénita". ${ }^{29}$ É dizer, preenchem o quadro dos conhecimentos fortuitos os fatos recolhidos por meio da realização legal de um meio de obtenção de prova autorizado judicialmente para a investigação de outro crime. De fato, o problema é suscitado naquelas situações em que

(...) habiéndose obtenido la correspondiente habilitación judicial para la práctica de una diligencia que afecta a los derechos fundamentales del sujeto investigado (entrada y registro en domicilio, intervención de las comunicaciones), con motivo de la persecución de una serie de conductas delictivas concretas y determinadas, aparecen fuentes de prueba relativas a otro u otros delitos distintos, de los cuales no se tenían noticias con anterioridad (...). ${ }^{30}$

\footnotetext{
${ }^{28}$ Processo Penal Constitucional. 6.ed. São Paulo: Revista dos Tribunais, 2010. p.19. O autor esclarece que "A história do processo penal é marcada por movimentos pendulares, ora prevalecendo ideias de segurança social, de eficiência repressiva, ora predominando pensamentos de proteção ao acusado, de afirmação e preservação de suas garantias. Essa diversidade de encaminhamentos são manifestações naturais da eterna busca de equilíbrio entre o ideal de segurança social e a imprescindibilidade de se resguardar o indivíduo em seus direitos fundamentais. Essa dicotomia é, em regra, representada pelo confronto entre eficiência e garantismo no processo penal". Ainda sobre o tema, cf. FERNANDES, Antonio Scarance. Reflexões sobre as noções de eficiência e de garantismo no processo penal. In: ; ALMEIDA, José Raul Gavião de; MORAES, Mauricio Zanoide de (Coords.). Sigilo no processo penal: eficiência e garantismo. São Paulo: Revista dos Tribunais, 2008. p.9-28.

${ }^{29}$ CARBONE, Carlos Alberto. Requisitos constitucionales de las intervenciones telefónicas: correspondencia telefónica, informática y audiovisual intervenida judicialmente en el proceso penal. Santa Fe: RubinzalCulzoni, 2008. p.370.

${ }^{30}$ ECHARRI CASI, Fermín Javier. Prueba ilícita: conexión de antijuridicidad y hallazgos casuales. In: Revista del Poder Judicial. Madrid, nº 69, p.261-301, 2003. p.286.
} 
Fala-se então em conhecimento fortuito, quando a informação sobre determinada infração penal é obtida a partir da realização de uma diligência restritiva a direito individual, regularmente autorizada e executada para a investigação de outro crime. Por exemplo, as informações obtidas em interceptação telefônica ou busca e apreensão domiciliar, relativas a terceira pessoa, ou a outro fato, que não constavam da decisão judicial autorizadora e, portanto, não havia indício justificativo para sua restrição.

Resta claro que as provas obtidas sem observância dos requisitos e/ou das condições de validade do meio de obtenção de prova escapam ao conceito de conhecimentos fortuitos. Assim, não se confunde a figura dos conhecimentos fortuitos sobre fatos recolhidos por meio da realização legal de um meio de obtenção de prova autorizado judicialmente com aqueles conhecimentos obtidos através de

(...) actos de injerencia que no sean dictados por un juez competente a pedido de la acusación pública en el marco de un proceso penal incoado por un delito concreto, o que habiéndose ordenado por un juez no guarden las formalidades prescriptas por la ley de forma (no haber sido ordenadas por auto fundado, por provenir de una orden de registro genérica, etc.). ${ }^{31}$

Estes casos, na verdade, representam nada mais do que hipótese de aplicação do princípio da inadmissibilidade das provas obtidas ilicitamente, e os conhecimentos daí decorrentes estarão contaminados (teoria dos frutos da árvore envenenada). ${ }^{32}$

Insista-se: na presente delimitacão do tema do encontro fortuito, a obtencão de prova de crime diverso é precedida de um procedimento lícito.

Mas para enquadrar devidamente o tema, agora, o que importa, é aclarar a compreensão e extensão da categoria conhecimentos fortuitos.

\footnotetext{
31 TAPIA, Juan Francisco. Descubrimientos accidentales en el curso de un registro domiciliario o una intervención de comunicaciones. El problema de los hallazgos casuales o "causales"? In: Revista de Derecho Penal. Buenos Aires, n 2, p.669-684, 2002. p.676.

32 Embora a problemática possibilite diversos desdobramentos - controvertidos e polêmicos -, ela não é objeto do presente estudo, merecendo mera referência a questão das provas ilícitas por derivação apenas para fins de estabelecer, em apertada síntese, que a teoria dos frutos da árvore envenenada, cuja origem é atribuída à jurisprudência da Suprema Corte norte-americana (fruits of the poisonus tree), ao sugerir que os vícios da árvore são transmitidos aos seus frutos, pressupõe a inadmissibilidade das provas derivadas das ilícitas (princípio da contaminação). Como registra AURY LOPES JUNIOR, a "lógica é muito clara, ainda que a aplicação seja extremamente complexa, de que se a árvore está envenenada, os frutos que ela gera estarão igualmente contaminados (por derivação)". (Direito Processual Penal e sua Conformidade Constitucional. v.1. 5.ed. Rio de Janeiro: Lumen Juris, 2010. p.590).
} 
Alguns autores preferem distinguir os conhecimentos fortuitos em dois tipos: (1) aqueles que, de algum modo, contêm uma conexão com o delito investigado, seja objetiva, quando, por exemplo, o monitoramento das comunicações telefônicas leva ao conhecimento de um novo crime praticado para ocultar aquele que se investigava, seja subjetiva, porque revela outras pessoas como partícipes ou coautoras do crime objeto da investigação; e (2) quando o conhecimento obtido fortuitamente está totalmente desconectado do delito investigado.

Outros optam por traçar uma distinção entre os conhecimentos fortuitos e os chamados conhecimentos da investigação.

Esta fronteira entre os conhecimentos fortuitos e os conhecimentos da investigação - distinção usual na doutrina portuguesa - é tênue, mas vai influir sobremaneira na condução de uma solução para a problemática, já que consoante a classificação dada aos fatos obtidos, dependerá o tratamento processual a dispensar quanto à admissibilidade da prova obtida e sua valoração.

Por isso, "Hão-de, noutros termos, precisar-se as fronteiras entre os factos a levar à conta de conhecimentos fortuitos e aqueles que, inversamente, terão de imputar-se à própria investigação e são, hoc sensu, conhecimentos da investigação". ${ }^{33}$

Afinal, por um lado, não se tem dúvidas de que se insere no conceito de conhecimentos fortuitos a obtenção de informação de crime diverso que em nada se relaciona com o crime investigado motivador e legitimador da medida restritiva, "podendo este não relacionamento ser objetivo ou subjetivo". 34 Mas e aqueles conhecimentos que, embora não se reportem ao crime cuja investigação legitimou a realização da medida, lhe são conexos, ou mesmo se inserem em uma mesma cadeia de fatos atribuídos à pessoa investigada?

Logo, "para que se possa compreender melhor o âmbito dos conhecimentos fortuitos, é necessário começar por desenhar uma distinção entre estes e os conhecimentos

\footnotetext{
33 ANDRADE, Manuel da Costa. Sobre as Proibições de Prova em Processo Penal. Coimbra: Coimbra Editora, 2006. Reimpressão da obra de 1992. p.305.

${ }^{34}$ VALENTE, Manuel Monteiro Guedes. Conhecimentos fortuitos: a busca de um equilíbrio apuleiano. Coimbra: Almedina, 2006. p.67.
} 
da investigação",35, ainda que não se pretenda nesse momento contrapor em termos exaustivos as duas categorias.

MANUEl DA COSTA ANDRADE, numa primeira aproximação ao tema, trata esta distinção no âmbito das escutas telefônicas, mas o raciocínio aproveita a hipótese de encontro fortuito no cumprimento de mandados de busca: “devem, desde logo, ter-se por pertinentes aos conhecimentos da investigação os factos que estejam numa relação de concurso ideal e aparente com o crime que motivou e legitimou a investigação por meio da escuta telefônica". ${ }^{36}$ Segundo RIESS, citado por MANUEL DA COSTA ANDRADE, estes conhecimentos da investigação "integram o processo histórico que a seu tempo ofereceu o motivo para uma ordem legítima de escuta". ${ }^{37}$

Para o autor português FrANCISCO AGUILAR, os conhecimentos fortuitos definirse-iam, negativamente (caráter residual), face aos conhecimentos da investigação, sendo estes os fatos obtidos por meio de uma escuta telefônica legalmente efetuada, "que se reportam ou ao crime cuja investigação legitimou a realização daquela ou a um outro delito (pertencente ou não ao catálogo legal) que esteja baseado na mesma situação histórica de vida (historischen Lebenssachverhalt) daquele". ${ }^{38}$ Isto é, entre a ação do catálogo cuja investigação determinou a realização da interceptação e a ação desta forma descoberta "terá de haver uma identidade de investigação no sentido processual". 39

Com razão, MANUEL DA COSTA ANDRADE afirma que:

De monta são, desde logo, as dificuldades e aporias que se deparam à definição dos conhecimentos da investigação. (...) Uma tarefa imposta pela necessidade de demarcar, com a segurança possível, aqueles conhecimentos dos conhecimentos fortuitos, a requerer um tratamento distinto. ${ }^{40}$

\footnotetext{
${ }^{35}$ SANTOS, Inês Moreira. Direito fundamental à privacidade vs. persecução criminal: a problemática das escutas telefônicas. In: MIRANDA, Jorge; SILVA, Marco Antonio Marques da (Coord.). Tratado LusoBrasileiro da Dignidade Humana. 2.ed. São Paulo: Quartier Latin, 2009. p.117.

${ }^{36}$ Sobre as Proibições... op.cit., p.306.

${ }^{37}$ Ibid., p.306.

${ }^{38}$ Dos conhecimentos fortuitos obtidos através de escutas telefónicas: contributo para o seu estudo nos ordenamentos jurídicos alemão e português. Coimbra: Almedina, 2004. p.17.

Cumpre esclarecer que o ordenamento lusitano estabelece um sistema de catálogo de crimes (artigo $187 \mathrm{n}^{\circ} \mathrm{s} 1$ e 2) relativamente aos quais é admissível recorrer à interceptação telefônica como meio de obtenção de prova, conforme se verá no ITEM 4.2.

${ }^{39}$ Ibid., p.18.

${ }^{40}$ Sobre as Proibições... op.cit., p.281-282.
} 
Com isto em mente, refere-se à importância de, nesse momento, limitar-se a assinalar que os conhecimentos da investigação configuram uma categoria distinta dos conhecimentos fortuitos, a exigir tratamento processual distinto.

Voltar-se-á ao tema quando, enfim, se partir em busca de um critério suscetível de determinar o âmbito de admissibilidade dos conhecimentos obtidos em investigação por crime diverso, oportunidade em que se avaliará se esta distinção feita pela doutrina estrangeira é suficiente para distinguir uns e outros elementos de prova colhidos no curso de uma busca domiciliar ou de uma interceptação telefônica.

\subsection{Conhecimentos fortuitos e inviolabilidades constitucionais em jogo}

A figura dos conhecimentos fortuitos está atrelada à obtenção de provas através de um meio ofensivo a direitos fundamentais pessoais - a reserva da intimidade, da vida privada, inviolabilidade das comunicações e do domicílio - consagrados constitucionalmente.

De fato, o tema apresenta-se “(...) como um desafio que imbrica com os direitos fundamentais do cidadão, cuja relevância se eleva se inserido em um processo penal que se quer e se deseja democrático (...)". ${ }^{41}$ Por isso mesmo, para encaminhamento da solução, é necessário remontar à natureza das coisas.

Irradiações da consagração da dignidade da pessoa humana como princípio fundante da República Federativa do Brasil (art.1º, III, CF), são várias as inviolabilidades afirmadas no artigo $5^{\circ}$ da Constituição Federal para resguardo dos direitos fundamentais da pessoa $^{42}$, e que interessam ao presente estudo, sobretudo porque refletem no campo processual penal, muitas vezes contrapondo-se à necessidade de obtenção de provas.

\footnotetext{
${ }^{41}$ VALENTE, Conhecimentos fortuitos... op.cit., p.129.

${ }^{42}$ Deve-se lembrar aqui o artigo 12 da Declaração Universal dos Direitos Humanos (1948), segundo o qual "Ninguém será sujeito a interferências na sua vida privada, na sua família, no seu lar ou na sua correspondência, nem a ataques à sua honra e reputação. Toda pessoa tem direito à proteção da lei contra tais interferências ou ataques." E também o artigo 11 da Convenção Americana sobre Direitos Humanos, cujo texto foi aprovado em São José da Costa Rica em 22/11/1969, e que integra o sistema constitucional brasileiro (Decreto 678/1992), protegendo a honra e a dignidade, assegurando que "1. Toda pessoa tem direito ao respeito da sua honra e ao reconhecimento de sua dignidade. 2. Ninguém pode ser objeto de ingerências arbitrárias ou abusivas em sua vida privada, em sua família, em seu domicílio ou em sua
} 
$\mathrm{O}$ inc. $\mathrm{X}$ consagra como invioláveis "a intimidade, a vida privada, a honra e a imagem das pessoas", valores que constituem os chamados direitos da personalidade ${ }^{43}$ e surgem como consequência da consagração da dignidade da pessoa humana, valor supremo da ordem constitucional brasileira.

Corolários do direito à intimidade, mais adiante, o inc. XI trata da inviolabilidade do domicílio, fazendo, porém, a ressalva quanto ao ingresso por meio de ordem judicial, se de dia, e de hipótese de flagrante delito, mesmo à noite. E logo a seguir, o inc. XII garante a inviolabilidade do sigilo das comunicações telefônicas, mas admite, indubitavelmente, sua quebra para realização de prova criminal, nas hipóteses e na forma que a lei estabelecer, através de ordem judicial. Na verdade, os direitos à intimidade e privacidade se desdobram ainda em diversos outros direitos, nestes compreendidos o direito ao sigilo bancário, sigilo fiscal, sigilo de dados etc.

As provas obtidas em desrespeito a essas garantias constituem prova ilícita e, assim, não podem ser admitidas (art. 5 $, \mathrm{LVI}, \mathrm{CF}$ ), ou seja, não podem ingressar no processo, e se, apesar disso, forem incorporadas aos autos, não poderão ser valoradas pelo juiz. Tanto que a Lei 11.690/2008, que alterou dispositivos do Código de Processo Penal relativos à prova, conferindo nova redação ao artigo 157, estabeleceu de forma explícita como consequência de, mesmo com a proibição, a prova ter ingressado no processo, o seu desentranhamento. De fato, nesses casos, não há outro caminho a não ser a descontaminação do feito, expurgando dos autos todos os elementos colhidos ilicitamente, inclusive os deles derivados.

Como já assinalado no ITEM 1.2, prova ilícita é aquela "colhida infringindo-se normas ou princípios colocados pela Constituição e pelas leis, frequentemente para a

correspondência, nem de ofensas ilegais à sua honra ou reputação. 3. Toda pessoa tem direito à proteção da lei contra tais ingerências ou tais ofensas."

${ }^{43}$ Como destaca José RAUl GaVião DE Almeida: "Paulo José da Costa Jr, ancorado no jurista alemão Henkel, ao tratar da vida particular estabelece-lhe três graus de intensidade. Anota que o maior raio das esferas concêntricas atinentes à vida privada alcança os comportamentos e acontecimentos que se quer distantes do alcance do público (privacidade strictu sensu ou privatsphäre), como o direito de resguardo da imagem. No segundo grau coloca o âmbito da intimidade, reservado a pessoas de confiança (vertrauensphäre), como sucede em determinadas questões de família. Por final, destaca o âmbito da intimidade que alcança uma parcela, ainda mais restrita de pessoas, não sendo o segredo compartilhado com mais ninguém além delas (geheimsphäre), como acontece com certos segredos profissionais. A essas esferas acresça-se a uma quarta ainda mais restrita, a da intimidade oculta, que abarca todos os segredos que não se quer compartilhar, mas reservar à própria consciência. (...) Todas as esferas da vida privada, em maior ou menor grau, são merecedoras de proteção na sociedade moderna, porque o respeito à privacidade surge como reação ao absolutismo e em decorrência do desenvolvimento dos direitos da personalidade." (Anotações acerca do direito à privacidade. In: MIRANDA, Jorge; SILVA, Marco Antonio Marques da (Coord.). Tratado Luso-Brasileiro da Dignidade Humana. 2.ed. São Paulo: Quartier Latin, 2009. p.720.) 
proteção das liberdades públicas e dos direitos da personalidade e daquela sua manifestação que é o direito à intimidade." ${ }^{44}$

Por isso, com razão, a proteção da intimidade é apontada por ADA PELLEGRINI GRINOVER como "o pano de fundo do processo penal, na medida em que o Estado, na persecução dos fins punitivos, exerce atividades investigatórias que levam quase necessariamente a uma intromissão na esfera privada do indivíduo". ${ }^{4}$

É que, mesmo elevadas à categoria de direitos fundamentais, estas inviolabilidades constitucionais não são absolutas, devendo haver uma conciliação com o direito à prova, de modo que este, em determinadas situações, levará a uma restrição daquelas, na busca de um equilíbrio entre o interesse público na persecução criminal e o interesse privado na preservação da intimidade. Consoante assinala ADA PELLEGRINI GRINOVER, desde há muito tempo, deve haver um equilíbrio entre as garantias constitucionais, uma vez que "as liberdades públicas não podem ser entendidas em sentido absoluto, em face da natural restrição resultante do princípio da convivência das liberdades". 46

Mas SCARANCE FERNANDES destaca a preocupação em sacrificar na menor medida possível os direitos fundamentais do acusado, inclusive no desenvolvimento da atividade probatória:

Não se pode, em nome da segurança social, compreender uma garantia absoluta da privacidade, do sigilo, no processo penal, mas também não se pode conceber, em homenagem ao princípio da verdade real, que a busca incontrolada e desmedida da prova possa, sem motivos ponderáveis e sem observância de um critério de proporcionalidade, ofender sem necessidade o investigado ou o acusado em seus direitos fundamentais e no seu direito a que a prova contra si produzida seja obtida por meios lícitos. ${ }^{47}$

De fato, sobretudo no processo de elaboração e conceituação da teoria da proporcionalidade, "utilizada hoje como um indispensável critério hermenêutico na

\footnotetext{
${ }^{44}$ GRINOVER; FERNANDES, GOMES FILHO, As nulidades... op.cit., p.125.

${ }^{45}$ Novas tendências do direito processual. Rio de Janeiro: Forense Universitária, 1990. p.60.

${ }^{46}$ Ibid., p.60.

${ }^{47}$ Processo Penal Constitucional... op.cit., p.81.
} 
aplicação do Direito" ${ }^{48}$ orientado pela vedação do excesso e da máxima efetividade dos direitos fundamentais, consolida-se o entendimento de que só se justificam restrições a direitos individuais, em face da Constituição, por razões de necessidade, adequação e supremacia do valor a ser protegido em confronto com aquele a ser restringido (proporcionalidade em sentido estrito). ${ }^{49}$

\subsection{Princípio da especialidade: o problema do desvio da vinculação causal nos conhecimentos fortuitos}

Manifestação da teoria da proporcionalidade é a necessidade de que uma medida restritiva a direito individual para fins de obtenção de prova criminal só possa ser autorizada por meio de uma decisão judicial circunstanciada, limitada ao contexto jurídico e fático em que deferida.

Trata-se de uma postura de respeito à necessidade de que uma medida excepcional, como instrumento de investigação de prova que gera restrições a direitos individuais, seja imposta por um juiz (requisito da judicialidade). E ao princípio da especialidade da prova, segundo o qual "la resolución judicial se otorga para una investigación específica y determinada, es decir, es una resolución especialmente otorgada para ese objeto de investigación concreto y no para otro". 50 AURY LOPES JUNIOR enfatiza que:

Há todo um contexto jurídico e fático necessário para legitimar a medida que institui uma "especialidade" da medida. Ou seja, a excepcionalidade e lesividade de tais medidas exigem uma eficácia limitada de seus efeitos e, mais ainda, uma vinculação àquele processo. Trata-se de uma vinculação causal, em que a autorização judicial para a obtenção da prova naturalmente vincula a utilização naquele processo (e em relação àquele caso penal), sendo assim, ao mesmo tempo, vinculada e vinculante. Essa decisão, ao mesmo tempo em que está vinculada ao pedido (imposição do sistema acusatório), é vinculante em relação ao material colhido (...). ${ }^{51}$

${ }^{48}$ OLIVEIRA, Eugenio Pacelli de. Curso de Processo Penal. 10.ed. Rio de Janeiro: Lúmen Júris, 2008. p.302.

${ }^{49}$ FERNANDES, Processo Penal Constitucional... op.cit., p.52-53.

${ }^{50}$ ECHARRI CASI, Prueba ilícita... op.cit., p.287.

${ }^{51}$ Direito Processual Penal... op.cit., p.574. 
De fato, no estudo dos meios de obtenção de prova na esfera criminal, um dos princípios que regem o tema é o da especialidade, "el cual implica que debe existir una necesaria identidad entre el delito-objeto de investigación y el que de hecho se investiga". 52 Ora, "outro não pode ser o tratamento da prova que - por limitar direitos fundamentais exige e impõe a reserva de jurisdição como garantia (e limite ao exercício do poder)". ${ }^{53}$

Mas no cumprimento dos mandados de busca e apreensão expedidos, assim como no curso da interceptação telefônica autorizada judicialmente, os agentes públicos estão sujeitos ao encontro casual de prova de infração penal diversa e desvinculada daquela que fundamentou o pedido e originou a providência restritiva.

Assim, no âmbito do desvio causal no cumprimento destas medidas judicialmente determinadas e limitadas é que o tema dos conhecimentos fortuitos se insere no estudo da regra da inadmissibilidade das provas ilícitas, sobretudo como forma de recusa àquilo que AURY LOPES JUNIOR chama de "substancialismo inquisitorial" "54, quando se desvia o foco da investigação da prova autorizada, sob pena de se admitir o abuso do poder de polícia e as investigações abertas e indeterminadas.

Todavia, se de um lado a questão presta-se a impedir o incentivo à prática do abuso de autoridade, sob a regência do princípio da especialidade da prova, que justifica que a limitação a direitos fundamentais esteja restrita à apuração do crime que ensejou a decisão judicial, por outro, há uma crescente preocupação no sentido de reconhecer a licitude das provas fortuitamente alcançadas em face do necessário equilíbrio entre garantismo e eficiência no processo penal. Como se resolve então a (i)licitude decorrente da extrapolação dos poderes conferidos pela autorização judicial para fins de aproveitamento desta descoberta enquanto prova?

Neste particular, é que se revela a importância e atualidade do tema, merecendo reflexão o conhecimento fortuito em virtude do cumprimento de mandados de busca e apreensão e no curso do monitoramento das comunicações telefônicas, se inexistente qualquer relação entre os motivos e finalidades determinantes da ordem originária e a descoberta casual.

\footnotetext{
${ }^{52}$ TAPIA, Descubrimientos accidentales... op.cit., p.673.

${ }^{53}$ LOPES JUNIOR, Direito Processual Penal... op.cit., p.575.

${ }^{54}$ Segundo o autor, "a vinculação causal da prova (especialidade) é decorrência natural da adoção de um processo penal minimamente evoluído, como forma de recusa ao substancialismo inquisitorial, e as investigações abertas e indeterminadas". (Ibid., p.575).
} 
Desse modo, pressuposta a realização legal de uma interceptação telefônica ou de uma busca e apreensão, qual o tratamento jurídico a dispensar, na construção de MANUEL DA COSTA ANDRADE, aos "conhecimentos ou factos fortuitamente recolhidos, isto é, que não se reportam ao crime cuja investigação legitimou a sua realização"? ${ }^{55}$ Deverão todos eles ser valorados? Ou, pelo contrário, deverá a valoração deles ser, de plano, recusada? E se o crime descoberto possuir uma relação causal com o objeto da investigação, dentro, por exemplo, de uma mesma cadeia de fatos conexos e atribuídos à pessoa cujas comunicações telefônicas foram interceptadas?

$\mathrm{Na}$ verdade, o tema encontra eco, majoritariamente, no quadro doutrinal das interceptações telefônicas; entretanto o problema, também, é suscitado na busca e apreensão, indagando-se o valor que se atribui aos conhecimentos estranhos ao objeto da investigação que originou a diligência. Como adverte GERALDO PRADO: "Não se trata de privilégio das interceptações telefônicas. Também na busca e apreensão poderá ocorrer encontro fortuito". 56

Mas isso não significa que a figura dos conhecimentos fortuitos esteja atrelada à obtenção de provas somente através desses meios. Por certo é que uma interceptação ambiental, ou a infiltração de um agente, por exemplo, também podem levar à obtenção fortuita de informações relativas a terceira pessoa ou a outro fato que não constavam da decisão judicial autorizadora dessas medidas.

\footnotetext{
${ }^{55}$ Sobre as Proibições... op.cit., p.304.

${ }^{56}$ Limite às interceptações telefônicas e a Jurisprudência do Superior Tribunal de Justiça. 2.ed. Rio de Janeiro: Lúmen Júris, 2006. p.59-60.
} 


\section{OS CONHECIMENTOS FORTUITOS NO ÂMBITO DOS MEIOS DE OBTENÇÃO DE PROVA}

O que se pretende aqui, para melhor situar a discussão, é demonstrar as variáveis que podem incidir no que se refere ao encontro casual de informações e objetos, dadas as particularidades normativas do regime processual penal dos diversos meios de obtenção de prova, aproximando-os do tema dos conhecimentos fortuitos.

No entanto, assume-se um corte epistemológico do trabalho: a análise dos conhecimentos fortuitos que se propõe a fazer não passa pela análise de todos os meios de obtenção de prova, tendo como foco principal a interceptação das comunicações telefônicas e a busca domiciliar.

\subsection{Interceptação das comunicações telefônicas}

\subsubsection{Sigilo das comunicações telefônicas e inviolabilidade da intimidade}

A inviolabilidade do sigilo das comunicações telefônicas é garantida pela Constituição Federal, no art. $5^{\circ}$, inc. XII, dispositivo que resguarda tanto a liberdade de manifestação do pensamento quanto o direito à intimidade.

Mas este sigilo gera reflexos no campo processual penal, muitas vezes contrapondo-se à necessidade da produção de prova; daí a ressalva expressa na parte final do próprio dispositivo constitucional quanto à possibilidade de restringi-lo "por ordem judicial, nas hipóteses e na forma que a lei estabelecer para fins de investigação criminal ou instrução processual penal".

De fato, o conteúdo secreto da informação transmitida pode constituir fonte de prova, daí porque, da necessidade de encontrar o equilíbrio entre o interesse público na persecução criminal e o interesse privado na preservação da intimidade, surge a 
possibilidade (excepcional) de interceptação das comunicações telefônicas como meio de obtenção de prova. ${ }^{57}$

Entende-se por interceptação telefônica, em sentido estrito, a captação da conversa por terceiro, sem o conhecimento dos interlocutores, que se efetiva pelo grampeamento do telefone. Havendo consentimento de um dos interlocutores para a efetivação da interceptação, utiliza-se a denominação escuta telefônica, o que, no entanto, não desnatura sua característica de interceptação telefônica, uma vez que também realizada por terceiro. O que importa é que a configuração destas exige sempre a intervenção de um terceiro estranho à conversa. ${ }^{58}$

Para além disso, segundo TORQUATO AvOLIO, o que resulta essencial à noção de interceptação é que esse terceiro esteja "investido do intuito de tomar conhecimento de circunstâncias, que, de outra forma, lhe permaneceriam desconhecidas". 59

Por isto mesmo, a interceptação se destaca por ser um instrumento reconhecidamente eficaz para fins de obtenção da prova. Entretanto, MANUEL DA CostA ANDRADE alerta para o elevado potencial de "danosidade social" da interceptação das comunicações telefônicas:

No panorama dos meios de obtenção da prova, as escutas telefónicas sobressaem ainda, para além da sua eficácia do ponto de vista da perseguição penal, pela sua manifesta e drástica danosidade social. Isto atento quer o número de direitos ou interesses atingidos, quer a gravidade da respectiva lesão. ${ }^{60}$

E é justamente este teor particularmente drástico da danosidade, representada pela interceptação telefônica, que explica que se tenha procurado rodear a sua utilização das maiores cautelas, e daí que a sua admissibilidade esteja dependente de conjunto de exigentes pressupostos materiais e formais.

\footnotetext{
${ }^{57}$ Cumpre destacar que o meio de prova através do qual o resultado da interceptação é transposto e fixado no processo é, em regra, um documento.

${ }^{58}$ GRINOVER; FERNANDES; GOMES FILHO. As nulidades... op.cit., p.164-165.

${ }^{59}$ Provas ilícitas... op.cit., p.118.

${ }^{60}$ Sobre as Proibições... op.cit., p.281. A expressão "danosidade social" é utilizada pelo autor em vários trechos de sua obra para destacar o "teor particularmente drástico da ameaça representada pela escuta telefônica" (p.286) e o "teor particularmente elevado do seu potencial de ameaça" (p.283).
} 


\subsubsection{Interceptação telefônica e seus requisitos: a Lei 9.296/1996}

A Constituição Federal consagrou o direito fundamental ao sigilo das comunicações telefônicas, apenas ressalvando, em nome da relatividade de todos os direitos fundamentais, a possibilidade de restrição de tal sigilo quando decretada judicialmente a interceptação telefônica "nas hipóteses e na forma que a lei estabelecer para fins de investigação criminal ou instrução processual penal” (art. $5^{\circ}$, inc.XII).

Foi aí que, destinada a regulamentar a parte final do inciso constitucional, surgiu a Lei $\mathbf{n}^{0}$ 9.296/96, que (bem ou mal) estabelece os casos e o procedimento para a relativização deste direito fundamental, formalidades estas que devem ser seguidas a fim de conferir legitimidade constitucional a tal medida excepcional.

Com o advento da referida lei - calcada na ressalva constitucional - foram estabelecidas normas para a realização de monitoramentos telefônicos, sendo os seguintes dispositivos relevantes para o presente estudo:

\footnotetext{
Art. $2^{\circ}$ Não será admitida a interceptação de comunicações telefônicas quando ocorrer qualquer das seguintes hipóteses:

I - não houver indícios razoáveis da autoria ou participação em infração penal;

II - a prova puder ser feita por outros meios disponíveis;

III - o fato investigado constituir infração penal punida, no máximo, com pena de detenção.

Parágrafo único. Em qualquer hipótese deve ser descrita com clareza a situação objeto da investigação, inclusive com a indicação e qualificação dos investigados, salvo impossibilidade manifesta, devidamente justificada.
}

Art. 4. $^{\circ} \mathrm{O}$ pedido de interceptação da comunicação telefônica conterá a demonstração de que a sua realização é necessária à apuração de infração penal, com indicação dos meios a serem empregados.

Art. 5. ${ }^{\circ}$ A decisão será fundamentada, sob pena de nulidade, indicando também a forma de execução da diligência, que não poderá exceder o prazo de quinze dias, renovável por igual tempo uma vez comprovada a indispensabilidade do meio de prova.

A leitura dos dispositivos acima revela a preocupação do legislador com o caráter restritivo e excepcional da medida. Aliás, a estrita obediência às formalidades previstas na 
legislação regulamentadora é essencial para que a medida extrema seja lícita e admitida na investigação ou processo criminal.

Por certo, o art. $4^{\circ}$ estabelece o conteúdo mínimo do pedido de interceptação, exigindo demonstração de que sua realização é necessária à apuração da infração penal. É que o pedido formulado restringirá a decisão aos termos pleiteados: “o pedido, assim, delimita a decisão, que por sua vez, restringe o âmbito da investigação intrusiva". 61

Já o art. $2^{\circ}$, ao estabelecer - a contrario sensu ${ }^{62}$ - requisitos à determinação judicial de interceptação telefônica, exigiu, dentre outras formalidades, a existência de indícios razoáveis de autoria ou participação em infração penal (inc. I) punida com reclusão (inc. III) e a impossibilidade de a prova ser obtida por outros meios (inc. II). Na lição de SERGio PITOMBo:

Não se decreta a interceptação telefônica, em base de mera probabilidade ou plausibilidade da existência de direito ao asseguramento. Exigem-se indícios razoáveis de autoria, ou de concurso de pessoas, em fato, que se desenha ilícito ou típico: ocorrência concreta, jamais cogitação. ${ }^{63}$

É bom frisar que é necessário que a interceptação telefônica seja indispensável, conditio sine qua non para a apuração do crime. A medida não pode ser determinada para apurar se o cidadão, contra o qual inexiste qualquer indício, só mera suspeita, está ou não cometendo algum crime: é vedada a interceptação de prospecção!

Aliás, a legalidade da interceptação telefônica está ligada à sua noção de ultima ratio, pois não se pode autorizar a medida quando a prova puder ser feita por outros meios disponíveis, outros meios legais processuais. Tal indispensabilidade do meio de obtenção de prova, exigida pelo art. $2^{\circ}$, inc. II, Lei 9.626/96, busca evitar que uma medida tão invasiva seja precipitadamente utilizada em todo e qualquer caso, banalizando o monitoramento telefônico.

\footnotetext{
${ }^{61}$ AVOLIO, Provas ilícitas... op.cit., p.240.

${ }^{62}$ Com razão, ToRQuATo AvOlio comenta que "Ao invés de indicar claramente em que casos e mediante quais requisitos ocorrerá a interceptação telefônica, optou o legislador pela formulação negativa, ou seja, previu apenas as hipóteses em que a interceptação 'não será admitida'. Esse 'método por exclusão' (...) além de não se revelar de boa técnica legislativa, não se presta aos fins propostos pelo texto constitucional”. (Ibid., p.226-227).

63 Sigilo nas comunicações: aspecto processual penal. In: Boletim IBCCRIM. São Paulo, $\mathrm{n}^{\circ}$ 49, dezembro/1996. p. 07-08.
} 
Com efeito, é a inexistência de outros meios disponíveis para a obtenção da prova que revela a sua necessidade. Esta, de outro lado, integra o conceito de proporcionalidade. Ora, se é certo que nenhum direito fundamental é absoluto, porque limitado pelos demais, também é incontestável que o direito à intimidade, à vida privada e ao sigilo das comunicações telefônicas somente pode ser restringido se, em confronto com outro bem, em dada situação concreta, sua restrição corresponder à única maneira de garantir este valor. Por essa razão é que se tem proclamado que a interceptação telefônica somente deve ser utilizada em ultima ratio:

Quando "a prova puder ser feita por outros meios disponíveis", significa, enfim, a possibilidade de se alcançar o mesmo resultado com outros meios probatórios, menos drásticos e devassadores que a interceptação. Sendo viável a prova testemunhal ou pericial, por exemplo, não se deve determinar a interceptação. Não se trata de disponibilidade material dos órgãos da persecução penal, como bem explicou Lenio Luiz Streck, verbis: “... outros meios disponíveis não são os que, materialmente, a autoridade policial tenha à sua disposição, mas sim, os meios legais processuais. Caso contrário, a alegação da polícia de que não tem 'outro meio disponível' (p. ex.: falta de peritos etc.), já será bastante para o deferimento da escuta, o que, convenhamos, viria a solapar a lei e a Constituição".

A interceptação telefônica, em síntese, está regida pelo princípio da necessidade, que é expressão da "intervenção mínima", da "alternativa menos gravosa", ou da "subsidiariedade", em suma, subprincípio da proibição do excesso. Sua função principal consiste em "obrigar os órgãos do Estado a comparar as medidas restritivas aplicáveis que sejam suficientemente aptas para a satisfação do fim perseguido e eleger, finalmente, a que seja menos lesiva para os direitos dos cidadãos". ${ }^{64}$

Estando diante de um meio de obtenção de prova que viola direito fundamental assegurado constitucionalmente, tal só será necessário se, e somente se, não existir outra medida menos onerosa para o cidadão. Vale a pena citar a lição de CANOTILHO:

O princípio da exigibilidade também conhecido como princípio da necessidade ou da menor ingerência possível, coloca a tônica na ideia de que o cidadão tem direito à menor desvantagem possível. Assim, exigirse-ia sempre a prova de que, para a obtenção de determinados fins, não era possível adotar outro meio menos oneroso para o cidadão. ${ }^{65}$

${ }^{64}$ GOMES, Luiz Flávio; CERVINI, Raúl. Interceptação telefônica: Lei 9.296/96 de 24.07.96. São Paulo: Revista dos Tribunais, 1997. p. 182-183.

${ }^{65}$ Direito Constitucional e Teoria da Constituição. 3.ed. Almedina, 1999. p. 264. 
$\mathrm{O}$ inciso III do artigo $2^{\circ}$, por sua vez, regula requisito específico para realização da interceptação telefônica, qual seja, que o crime que está sendo investigado seja apenado com reclusão, optando o legislador pelo critério da qualidade da pena, o que, segundo MagalhãEs GoMes FILHO, nem de longe atende à natureza excepcional da previsão contida na parte final do art. $5^{\circ}$, inciso XII, da CF:

É que, longe de atender à natureza excepcional da previsão contida na parte final do art. $5^{\circ}$, inciso XII, da CF, a nova lei conferiu-lhe amplitude suficiente para propiciar o virtual aniquilamento do direito à intimidade assegurada pela cláusula constitucional. Com isso, torna-se cada vez mais evidente a distância entre o modelo garantista de processo penal esboçado pelo constituinte e a realidade legislativa.

De fato, ao restringir a utilização desse poderoso recurso técnico às hipóteses que a lei estabelecer para fins de investigação criminal ou instrução processual penal, não pretendeu a Constituição, certamente, outorgar uma carta branca para que o legislador ordinário autorizasse o seu emprego na apuração de todos os crimes punidos com reclusão, como faz o art. $2^{\circ}$, inc. III, da Lei 9.296/96. ${ }^{66}$

Na mesma linha, DAMÁSIO DE JESUS critica a adoção desse critério, o qual, pela sua extensão e limitação, se distancia dos modelos adotados pelos ordenamentos estrangeiros:

Quanto à extensão, numa interpretação literal, a medida é aplicável a todos os delitos apenados com reclusão (III), que estejam definidos na legislação penal comum ou especial $(\mathrm{CP}$, leis extravagantes, crimes militares, eleitorais etc.), pouco importando a sua gravidade objetiva, violando-se o princípio da proporcionalidade ou da reserva legal proporcional. É um exagero, por exemplo, admitir-se a violação telefônica em casos sem expressão lesiva, como furto de coisa de pequeno valor, apropriação indébita simples etc. Quando a Carta Magna excepcionalmente admitiu a interceptação telefônica, remetendo sua disciplina à legislação ordinária, obviamente pretendeu que se observasse proporcionalidade entre a proteção da intimidade e a segurança social. Nas legislações estrangeiras, restringe-se a medida a delitos graves, como homicídio, latrocínio, sequestro, extorsão mediante sequestro, tráfico de drogas, de mulheres e de crianças, terrorismo, sabotagem etc., estendendo-se a algumas poucas infrações de menor poder ofensivo, como a injúria, a molestação e ameaça por telefone. (...) No tocante à limitação, a lei restringe a diligência aos casos de crimes punidos com reclusão. Assim, não é admissível em relação a infrações que, apenadas

${ }^{66}$ A violação do princípio da proporcionalidade pela Lei 9296/96. In: Boletim IBCCRIM. São Paulo, nº 45, p.14, agosto/1996. 
com detenção ou prisão simples, a autorizariam, como a ameaça e a injuria pelo telefone (...). ${ }^{67}$

Com razão, SCARANCE FERNANDES afirma que mais importante seria determinar as infrações em que a interceptação seria admissível, porque, como meio de obtenção de prova, tanto pode ser útil em crimes de maior como de menor gravidade. Além disso, "a forma abrangente seguida pelo legislador ao prever a interceptação em todos os crimes punidos com reclusão é perigosa, podendo dar margem a abusos, sem o resultado positivo de melhoria na colheita de elementos de investigação ou de prova". ${ }^{6}$

Pois bem. No parágrafo único do artigo $2^{\circ}$, o legislador exige que seja descrita com clareza a situação objeto da investigação, o que significa uma delimitação da base fática da medida, inclusive com a indicação e qualificação dos investigados. São formalidades essenciais do requerimento e da decisão a respeito da interceptação, relacionadas ao objeto da investigação e ao sujeito passivo da medida, devendo a primeira estar delineada com clareza e o segundo suficientemente qualificado.

Ora, se "a interceptação não repousasse sobre um fato delituoso certo e determinado, daria margem a abusos, ferindo-se de morte a garantia do sigilo telefônico". 69 Por isso, como manda o parágrafo único do artigo $2^{\circ}$ da lei 9296/96, a investigação deve se ater ao objeto delimitado na decisão permissiva da interceptação telefônica.

Quanto ao indivíduo a ser investigado, a decisão judicial deve também indicar quem se investiga, até porque contra este residem os indícios de autoria, independentemente da titularidade da linha telefônica por ele utilizada. LUIZ FLÁviO GOMES tece importantes comentários sobre essa também necessária individualização do sujeito passivo da interceptação, destacando a indispensabilidade da obediência ao referido requisito, bem como, mesmo que não prevista expressamente em lei, a individualização da linha a ser interceptada:

\footnotetext{
${ }^{67}$ Interceptação de comunicações telefônicas: notas à Lei 9.296, de 24.07.1996. In: Revista dos Tribunais, São Paulo, no 735, p.458-473, jan/1997. p.465.

${ }^{68}$ Processo Penal Constitucional... op.cit., p.97-98. VICENTE GRECO FILHO é categórico ao afirmar que “a possibilidade de interceptação telefônica com relação a todos os crimes punidos com reclusão precisa ser restringida, porque muito ampla. Há muitos crimes punidos com reclusão que, de forma alguma, justificariam a quebra do sigilo das comunicações telefônicas, considerando-se especialmente o 'furor incriminatório' de que foi tomado o legislador nos últimos anos e, em muitos casos, a desproporcionalidade da pena cominada". (Interceptação telefônica: considerações sobre a Lei $\mathrm{n}^{\circ}$ 9.296, de 24 de julho de 1996. 2.ed. São Paulo: Saraiva, 2008. p.22).

${ }^{69}$ AVOLIO, Provas ilícitas... op.cit., p.227.
} 


\begin{abstract}
A perfeita individualização do "sujeito passivo" da interceptação possui inúmeras razões: porque não é possível interceptação genérica, muito menos de "prospecção", porque estamos diante de uma medida excepcional e reconhecidamente invasora da privacidade e intimidade alheias, porque em matéria de direitos fundamentais as exceções devem afetar o mínimo possível a essência do direito etc. Dentre tantas outras mais, uma merece destaque especial: é imprescindível a individualização do sujeito passivo (...).

Mas não só é fundamental a indicação dos investigados. Urge também a indicação e correta individualização da linha telefônica que será interceptada. Faz-se mister a indicação do seu número. É essencial a indicação do número ou números das linhas investigadas. E não pode haver ampliação da autorização judicial, por conta dos encarregados da execução da medida. Na eventualidade de que surja a necessidade de interceptações de outras linhas telefônicas, é preciso novo pedido ao Juiz. $^{70}$
\end{abstract}

Veja-se que, como forma de tutelar o direito fundamental à intimidade, o legislador infraconstitucional, bem ou mal, delineou as hipóteses de cabimento da interceptação das comunicações telefônicas, aduzindo que na decisão autorizadora deve o juiz delimitar o objeto da investigação, bem como a pessoa investigada, sendo possível quanto a esta última hipótese que a medida seja deferida sem a identidade completa do investigado, embora se saiba quem é, já que contra ele pesam os indícios de autoria. ${ }^{71}$

Ocorre que, apesar de o parágrafo único do artigo $2^{\circ}$ da lei 9.296/96 impor ao magistrado a delimitação do objeto da investigação, inclusive com a indicação dos investigados, a interceptação das comunicações telefônicas pode levar ao conhecimento fortuito de fato não apontado pela decisão judicial. Do mesmo modo, pode alcançar outras pessoas que não as investigadas.

\title{
3.1.3 Os conhecimentos fortuitos nas interceptações telefônicas
}

Conforme visto, a excepcionalidade deste meio de obtenção de prova conduziu o legislador ordinário, sob o paradigma constitucional, a limitá-lo aos termos da lei e para fins de investigação criminal. Assim, a busca de elementos probatórios deve se dar dentro

\footnotetext{
${ }^{70}$ Interceptação telefônica: Lei 9.296/96... op.cit., p.190-191.

${ }^{71}$ FONSECA, Tiago Abud da. Interceptação telefônica: a devassa em nome da lei. Rio de Janeiro: Espaço Jurídico, 2008. p.62.
} 
dos limites legais, em equilíbrio com a preservação dos direitos dos indivíduos, sobretudo intimidade e vida privada.

Mas, mesmo obedecendo-se às formalidades legais, identificada a pessoa investigada e o delito supostamente cometido, ainda assim, a interceptação telefônica judicialmente autorizada pode surpreender.

Tem-se que levar em conta que a comunicação telefônica interceptada impede, por motivos técnicos, que se separem as conversas que têm por objeto dados relativos à situação-objeto da investigação das demais conversas mantidas na linha interceptada. De fato, "existe uma impossibilidade fáctica de limitar a monitorização dos fluxos informacionais e comunicacionais aos factos ou conhecimentos que determinam a validade da ingerência". 72

Destarte, no curso da interceptação telefônica autorizada judicialmente, os agentes públicos estão sujeitos ao encontro casual de prova de infração penal diversa e desvinculada daquela que fundamentou o pedido e originou a providência restritiva. $\mathrm{E}$ mais, pode ser que no decorrer da interceptação telefônica judicialmente autorizada sejam incriminadas outras pessoas, identificadas somente após o início do procedimento.

Cumpre observar que a temática dos conhecimentos fortuitos em sede de interceptação telefônica "está ligada, por um lado, à realização de escutas de forma desmedida e em um número estrondoso - reflexo directo do direito penal moderno - e, por outro e como consequência do primeiro, à obtenção da notícia de determinados crimes se operar por meio das escutas telefónicas". 73

Reside nesse ponto a gênese da discussão do conhecimento fortuito, pois há que se enfrentar, por um lado, o problema do que for apurado em face de terceiros que se utilizam da mesma linha interceptada e daqueles interlocutores que se comunicam com o sujeito passivo da interceptação, e, de outro, o conhecimento dos fatos criminosos que não fundamentaram a interceptação e que surgem por ocasião dela. ${ }^{74}$

\footnotetext{
${ }^{72}$ RODRIGUES, Benjamim Silva. Das escutas telefônicas. Tomo I. Coimbra: Coimbra Editora, 2008. p.420.

${ }^{73}$ VALENTE, Conhecimentos fortuitos... op.cit., p.33-34.

${ }^{74}$ GRECO FILHO, Interceptação telefônica... op.cit., p.33.
} 


\subsubsection{Interceptação e conhecimento fortuito de fato diverso}

\section{Ada Pelegrini Grinover, Scarance Fernandes e Magalhães Gomes Filho} advertem que:

(... ) certamente surgirá na prática a dúvida a respeito de a prova obtida mediante interceptação telefônica, autorizada para investigação ou processo relativo à determinada infração penal, poder, ou não, ser utilizada em investigação ou processo instaurado por fatos diversos. Trata-se do conhecimento fortuito de outros fatos, ocasionado pela interceptação lícita. ${ }^{75}$

SCARANCE FERNANDES esquadrinha a seguinte situação: "Imagine-se que o juiz autorize interceptação a respeito da prática de tráfico de entorpecentes e, durante a operação, descobre-se a ocorrência de um delito de homicídio". ${ }^{76}$ E na sequência pondera:

Interpretação mais rigorosa da lei não permitiria que se utilizasse a prova obtida, porque não inserida no âmbito de autorização judicial. Outros, contudo, dirão que a prova foi regularmente obtida porque a interceptação estava autorizada e, por isso, tudo que foi colhido é lícito e, por isso, admissível no processo. ${ }^{77}$

De fato, embora a Lei 9.296/96, no parágrafo único do artigo $2^{\circ}$, exija a clara descrição da situação objeto da investigação, no curso da interceptação telefônica, os agentes públicos têm, muitas vezes e fortuitamente, conhecimento de fatos que não se reportam ao crime cuja investigação legitimou a medida restritiva, ou seja, "obtém um conhecimento fortuito de outro tipo legal de crime não impulsionador da escuta". ${ }^{78}$

Poderia a gravação feita ser utilizada como prova destes novos fatos delituosos descobertos? Afinal, como adverte GERALDO PRADO:

\footnotetext{
${ }^{75}$ As nulidades... op.cit., p. 175 .

${ }^{76}$ A lei de interceptação telefônica. In: PENTEADO, Jacques de Camargo (Org.). Justiça penal: críticas e sugestões: provas ilícitas e reforma pontual. v.4. São Paulo: Revista dos Tribunais, 1997. p.68.

${ }^{77}$ Ibid., p.68.

${ }^{78}$ VALENTE, Conhecimentos fortuitos... op.cit., p.74.
} 
É preciso ter o máximo de cuidado para evitar a manipulação do Poder Judiciário, provocado para autorizar interceptação telefônica acerca de delito determinado (intenção manifesta), quando na realidade o que se pretende é capturar provas de outra infração penal (intenção latente). ${ }^{79}$

Outra situação coloca a questão em cima da mesa no que se refere a informações obtidas em interceptação telefônica relativas a outro fato delituoso, não inserido no âmbito da autorização judicial: trata-se do encontro fortuito de prova de crime punido com detenção.

Note-se que o legislador ordinário estabeleceu que só será admitida a interceptação de comunicações telefônicas se o fato investigado constituir infração penal punida com reclusão (art. $2^{\circ}$, inc. III, Lei 9.296/96). Assim, será que, surgindo a informação sobre um crime punido com detenção no decorrer de uma interceptação judicialmente autorizada, poderá esta informação servir de prova dessa infração descoberta fortuitamente? Poderá ela servir de base para a deflagração de ação penal e ser valorada para a condenação pelo crime punido com detenção, uma vez que obtida dentro de um procedimento lícito?

\subsubsection{Interceptação indicando outra pessoa que não a investigada e contra quem fora concedida a autorização}

A quebra do sigilo das comunicações telefônicas "constitui certamente um meio poderoso e necessário posto à disposição do Estado para fins de obtenção da prova, mas também instrumento insidioso de quebra da intimidade, não só do interceptado, como também de terceiros que com ele se relacionam". 80

Por isso, o princípio da especialidade também repercute no aspecto subjetivo, com relação à pessoa que será objeto da medida, "la cual se deberá individualizar ya que es

\footnotetext{
${ }^{79}$ Limite às interceptações telefônicas: a jurisprudência do Superior Tribunal de Justiça no Brasil e a alteração introduzida no Código de Processo Penal Português (Lei no 48/2007). In: CARVALHO, Luis Gustavo Grandinetti Castanho de (Org). Processo Penal do Brasil e de Portugal: estudo comparado: as reformas portuguesa e brasileira. Coimbra: Almedina, 2009. p.135-136.

${ }^{80}$ GRINOVER, Ada Pellegrini. Do regime das interceptações telefônicas no projeto de novo CPP - proposta de emendas do IBDP. In: Boletim IBCCrim. São Paulo, ed. especial CPP, p.2-3, agosto/2010. p.2.
} 
necesario fundamentar las razones por las que se restringe su derecho al secreto de las comunicaciones". 81

Porém, como alerta MANuel Monteiro Guedes VAlente: "Pernicioso é o campo subjectivo da danosidade social por não poder ser 'tecnicamente possível limitar a escuta e a gravação' às pessoas com relevância para a investigação em curso, podendo atingir direitos de terceiros". ${ }^{82}$ De fato, como bem colocado por THIAGO ANDRÉ PIEROBOM DE ÁvILA, “a restrição do direito do terceiro é inevitável, pela impossibilidade de cisão do discurso". 83

Assim, pode-se pensar na hipótese de encontro de um terceiro como suspeito da prática do crime investigado, terceiro este que é pessoa diversa daquela cuja suposta autoria motivou o deferimento da medida. "Em tal hipótese, o fato investigado é o mesmo que o indicado e fundamentador do pedido, isto é, corresponde ao mesmo fato investigado: o suspeito é que surgiu como terceira pessoa". ${ }^{84}$

Não se trata aqui, de conhecimento fortuito, mas da apuração do verdadeiro autor do delito que se investigava através desse meio de obtenção de prova. Entendimento, aliás, adotado pelo Supremo Tribunal Federal no julgamento do HC 78.098, conforme consta de voto do relator Min. MoReIRA ALves:

Trata-se, pois, de hipótese em que o investigado, que é aquele em cujo nome está o telefone pelo qual se faz a comunicação relativa ao tráfico de drogas, é inocentado, mas em que o seu aparelho telefônico serve para outrem - que, na espécie, vive com ele em relação de concubinato - de utilizar-se para a prática desse crime. A Lei 9.296/96 foi omissa a esse respeito, mas em hipóteses como a presente, em que há denúncia de que para a prática do crime há a utilização de um determinado aparelho telefônico induz à investigação daquele em cujo nome consta esse aparelho, e da escuta autorizada se verifica que o crime deve ser imputado a outrem que com ele vive, não se trata, em rigor, sequer de crime descoberto ocasionalmente, mas da descoberta de seu verdadeiro autor em decorrência de investigação diretamente dirigida à apuração da ocorrência do delito e de sua autoria. Tendo em vista a lei 9.296/96, ao

${ }^{81}$ CARBONE, Requisitos constitucionales... op.cit., p.369.

${ }^{82}$ Conhecimentos fortuitos... op.cit., p.64.

${ }^{83}$ Provas ilícitas e proporcionalidade: uma análise da colisão entre os princípios da proteção penal eficiente e da inadmissibilidade das provas obtidas por meios ilícitos. Dissertação (Mestrado). Faculdade de Direito da Universidade de $\quad$ Brasília, 2006. p.221. Disponível em: <http://repositorio.bce.unb.br/bitstream/10482/3103/1/Disserta\%C3\%A7\%C3\%A3o\%20\%20THIAGO\%20A NDR\%C3\%89\%20PIEROBOM\%20DE\%20\%C3\%81VILA-\%20Provas\%20I1\%C3\%ADcitas.pdf>. Acesso em: 15/04/2012.

${ }^{84}$ ARANHA, Adalberto José Q. T. de Camargo. Da prova no processo penal. 7.ed. São Paulo: Saraiva, 2006. p.295. 
exigir que se individualize o investigando, o fez para que o juiz possa decidir com plenos elementos sobre a necessidade da interceptação de comunicações telefônicas, e não para que apenas se possa verificar se o autor do crime é necessariamente o investigando, tanto assim que admite que sequer se aponte o suspeito quando há impossibilidade de fazê-lo. ${ }^{85}$

De fato, lembrando que o parágrafo único do artigo $2^{\circ}$ da Lei 9.296/96 preocupase em exigir a indicação e a qualificação da pessoa investigada, salvo impossibilidade manifesta, devidamente justificada, TORQUATO AvOLIO comenta:

Assim, se a polícia tem conhecimento da ocorrência de um crime, mas ainda não possui um suspeito, a medida de interceptação poderá recair sobre pessoa indeterminada (limitada, como em todos os casos, a uma determinada linha telefônica, a ser indicada no pedido), pois o objetivo da diligência será mesmo a descoberta do autor do crime, em nada obstando ao deferimento da medida, se devidamente justificada no caso concreto. Da mesma forma, se a investigação já se iniciou em face de um determinado suspeito, e no curso dela se apurar autoria diversa (frise-se: quanto ao mesmo crime investigado), a prova em relação a essa outra pessoa é de ser reputada válida. Tal proceder não implica busca desarrazoada nem violação às garantias processuais. ${ }^{86}$

Mas, por outro lado, podem aparecer outros envolvidos com o mesmo fato investigado (coautores, partícipes), ou com outros fatos, diferentes daquele sob investigação e que motivou a decretação da quebra do sigilo da comunicação telefônica, e aqui, "as dificuldades subirão de tom à medida que os factos ou conhecimentos fortuitos se reportarem a infracções não imputáveis ao arguido ou suspeito", ${ }^{87}$

Lembre-se que as interceptações acabam por "atingir a esfera jurídica de pessoas que estão fora do círculo dos arguidos e suspeitos em relação aos quais foram ordenadas", o que "pode abrir a porta da devassa da privacidade de pessoas". ${ }^{8}$

\footnotetext{
${ }^{85}$ BRASIL. Supremo Tribunal Federal. $1^{\text {a }}$ Turma. Habeas Corpus 78.098/SC. Relator Ministro Moreira Alves. Julgado em 01/12/1998. DJ 06/08/1999. Acórdão disponível em: $<$ http://redir.stf.jus.br/paginadorpub/paginador.jsp?docTP=AC\&docID=77742 >. Acesso em: 13/07/2011.

${ }^{86}$ Provas ilícitas... op.cit., p.231-232.

${ }^{87}$ ANDRADE, Sobre as Proibições... op.cit., p.304.

${ }^{88}$ Ibid., p.282.
} 


\subsection{Busca e apreensão}

O problema dos conhecimentos fortuitos não se esgota na interceptação telefônica, sendo uma questão que tem relevância no quadro de outros meios de obtenção de prova de natureza excepcional, como a busca e apreensão.

Para fins do presente estudo, analisar-se-á a hipótese de busca domiciliar, restrição legal ao direito da inviolabilidade do domicílio assegurado na Constituição Federal. Sobre ela, de plano, pertinente registrar a tendência em ser deferida de forma bastante genérica.

E é esta característica que ressalta a aproximação deste meio de obtenção de prova com o tema do encontro fortuito, quando, no decorrer da diligência de busca domiciliar, surge a possibilidade de apreender objeto diverso daquele procurado, mas relevante para a comprovação de outro delito.

\subsubsection{Inviolabilidade domiciliar e busca e apreensão}

A Constituição Federal, no art. $5^{\circ}$, inc. XI, consagra a inviolabilidade domiciliar, declarando ser a casa ${ }^{89}$ asilo inviolável do indivíduo, só permitindo que nela se ingresse com consentimento do morador, exceto em caso de flagrante delito ou desastre, ou para prestar socorro, ou, durante o dia, por determinação judicial.

A busca domiciliar (e a apreensão) trabalha exatamente nessa exceção da proteção constitucional, de modo que não se deve pensá-la "desconectada do direito fundamental da intimidade e vida privada (art. $5^{\circ}$, inc. X), até porque a tutela do domicílio guarda uma

\footnotetext{
${ }^{89}$ Deve-se entender que a expressão casa, protegida constitucionalmente, comporta interpretação ampla. Como destaca CLEUNICE PITOMBO, a expressão abrange: “a) a habitação definitiva, ou morada transitória; b) casa própria, alugada ou cedida; c) dependências da casa, sendo cercadas, gradeadas ou muradas; d) qualquer compartimento habitado; e) aposento ocupado de habitação coletiva, em pensões, hotéis e em casas de pousada; f) estabelecimentos comerciais e industriais, fechados ao público; g) local onde se exerce atividade profissional, não aberto ao público; h) barco, trailer, cabine de trem ou navio e barraca de acampamento; i) áreas comuns de condomínio, vertical ou horizontal." (Da busca e da apreensão no processo penal. 2.ed. São Paulo: Revista dos Tribunais, 2005. p.72).
} 
conexão instrumental com esses direitos fundamentais e, todos eles, com o valor dignidade da pessoa humana". ${ }^{90}$ Segundo MAGalHãEs GOMES FILHO:

A proteção do espaço íntimo do homem e de sua família não constitui apenas uma exigência da ordem jurídica, mas representa, mais do que isso, uma necessidade biológica e social; assim, outras importantes limitações à prova no processo penal resultam da garantia da inviolabilidade do domicílio, que é, por sua vez, uma decorrência dos direitos fundamentais à intimidade e à segurança. ${ }^{91}$

Por isso, a legalidade da busca e da apreensão é assegurada, também, pela proteção da intimidade do indivíduo e de sua vida privada, valores diretamente envolvidos na realização da busca e apreensão penal:

Importa, porém, especialmente, no tocante à busca e apreensão, sempre, o respeito e acatamento à pessoa humana. Preservando-lhe, o máximo possível, a casa, a integridade física e moral, a intimidade e a vida privada. Sempre, porém, com a visão de que aludidas garantias, no caso, possuem relação de complementaridade. ${ }^{92}$

\subsubsection{Busca domiciliar: requisitos do mandado e condições de validade da execução da medida}

Conforme antecipado, a entrada em casa alheia para fins de investigação criminal encontra-se em constante tensão com princípios basilares do Estado de Direito: inviolabilidade do domicílio, dignidade da pessoa humana, intimidade e vida privada.

Assim, por se tratar de uma grave violação de direitos fundamentais, a busca domiciliar deverá observar rigorosamente seus limites formais: “A busca é uma violência estatal legitimada, mas que exige, para isso, a estrita observância das regras legais estabelecidas". 93

\footnotetext{
${ }^{90}$ LOPES JUNIOR, Direito Processual Penal... op.cit., p.692.

${ }^{91}$ Direito à Prova... op.cit., p.119.

${ }_{92}$ PITOMBO, Da busca e da apreensão... op.cit., p.88.

${ }^{93}$ LOPES JUNIOR, Direito Processual Penal... op.cit., p.700.
} 
No processo penal brasileiro, a busca domiciliar, em decorrência da barreira constitucional da inviolabilidade da casa, é sempre jurisdicional, sendo necessária a determinação judicial e, consequentemente, a expedição do mandado de busca. Excepcionalmente, sem autorização judicial, apenas com o livre e expresso consentimento do morador ou em caso de flagrante delito.

É um meio de obtenção de prova típico que visa preservar a fonte de prova para que, posteriormente, venha a ser introduzida no processo e possa ser valorada pelo órgão jurisdicional. Desse modo, nos termos do artigo $240, \S 1^{\circ}$, do Código de Processo Penal, "proceder-se-á à busca domiciliar, quando fundadas razões a autorizarem" não se justificará a medida. Veja-se que a lei exige fundadas razões, e essas não se confundem com meras suspeitas. Ora, como ato decisório, a autorização para entrada em casa alheia deve ser devidamente fundamentada, nos termos do artigo 93, inc. IX, da Constituição Federal. CLEUniCE PITOMBO, com razão, pondera:

A autoridade judicial, portanto, em nosso sistema processual penal, para
autorizar a busca domiciliar deve, de forma inequívoca, demonstrar, nos
"fundados motivos", que a restrição ao direito individual aflora
inafastável, para a persecução penal; evidenciar o interesse social
concreto, prevalecendo sobre o individual; ser proporcional ao fim
almejado; estar ajustada, em sua concretude, com a finalidade perseguida.
E, mais, patentear sua imprescindibilidade, oportunidade e
conveniência.

Destarte, a motivação passa a ser requisito essencial da medida, uma vez que torna possível o controle acerca dos pressupostos que a legitimam.

A lei processual determina que se expeça mandado judicial, no qual deve se encontrar especificado o que deve ser objeto da diligência. É que "o objetivo do mandado, além de outorgar o cumprimento da ordem a outro agente estatal, constitui o de delimitar o

94 “Art. 240. A busca será domiciliar ou pessoal.

$\S 1$ ํㅡㄹ Proceder-se-á à busca domiciliar, quando fundadas razões a autorizarem, para:

a) prender criminosos;

b) apreender coisas achadas ou obtidas por meios criminosos;

c) apreender instrumentos de falsificação ou de contrafação e objetos falsificados ou contrafeitos;

d) apreender armas e munições, instrumentos utilizados na prática de crime ou destinados a fim delituoso;

e) descobrir objetos necessários à prova de infração ou à defesa do réu;

f) apreender cartas, abertas ou não, destinadas ao acusado ou em seu poder, quando haja suspeita de que o conhecimento do seu conteúdo possa ser útil à elucidação do fato;

g) apreender pessoas vítimas de crimes;

h) colher qualquer elemento de convicção".

${ }^{95}$ Da busca e da apreensão... op.cit., p. 130. 
local em que se realizará a busca e assim como quais as coisas sobre as quais poderá recair a apreensão". ${ }^{96}$ Assim, outra condição de validade a que se submete a busca e apreensão judicial é a existência de mandado com especificações estritamente delimitadas.

Nesta linha de pensamento, observa-se que o próprio texto legal, no art. 243 do Código de Processo Penal, relaciona explicitamente os requisitos intrínsecos do mandado de busca:

Art. 243. O mandado de busca deverá:

I - indicar, o mais precisamente possível, a casa em que será realizada a diligência e o nome do respectivo proprietário ou morador; ou, no caso de busca pessoal, o nome da pessoa que terá de sofrê-la ou os sinais que a identifiquem;

II - mencionar o motivo e os fins da diligência;

III - ser subscrito pelo escrivão e assinado pela autoridade que o fizer expedir.

Gustavo BADARó, analisando o inciso II do dispositivo acima transcrito, esclarece o que se entende por motivo e fins da diligência:

O inc. II se refere aos motivos, isto é, à razão que levou ao deferimento da medida, em especial, o crime que é objeto da investigação e sua relação com o local ou com a pessoa que sofrerão a busca. Trata-se, pois, do motivo gerador da diligência. Por outro lado, os fins da diligência dizem respeito à identificação da pessoa ou coisa a ser buscada, delimitando com precisão o objeto da busca e, com isso, evitando abusos ou devassas desnecessárias e exorbitantes. ${ }^{97}$

Por isso, "ao contrário do que se costuma ver, a busca domiciliar não pode ser banalizada, deve ter uma finalidade clara, bem definida e estar previamente justificada pelos elementos da investigação preliminar". ${ }^{98}$ É que a finalidade da busca, no processo penal pátrio, volta-se para “o descobrimento do que se procura” (art.245, $\S 3^{\circ}$ do CPP).

Aliás, consoante alerta AURY LOPES JUNIOR, “os fins da diligência impõem a clara definição - de forma apriorística - do que se busca. Ou seja, impede-se a busca genérica de

\footnotetext{
${ }^{96}$ LEITE, Larissa. Medidas patrimoniais de urgência no processo penal: implicações teóricas e práticas. Rio de Janeiro: Renovar, 2011. p.261.

${ }^{97}$ Direito Processual Penal... op.cit., p.277.

${ }^{98}$ LOPES JUNIOR, Direito Processual Penal... op.cit., p.694.
} 
documentos e objetos" "99, como o que é, observa LARISSA LEITE, "lamentavelmente, possível verificar não raras vezes na prática forense, em determinações de apreensão de quaisquer papéis ou objetos que se possam consistir em prova, instrumento ou produto de crime". 100

Inadmissível, portanto, mandado de busca incerto, vago ou genérico, para evitar que a autoridade que o executa exceda a determinação judicial e, também, para que a pessoa submetida à medida ou as testemunhas do ato possam verificar se não estão sendo praticados abusos. Afinal,

(...) de que vale declarar, a Constituição, que "a casa é asilo inviolável do indivíduo" (art. $5^{\circ}, \mathrm{XI}$ ) se moradias são invadidas por policiais munidos de mandados que consubstanciem verdadeiras cartas brancas, mandados com poderes de a tudo devassar, só porque o habitante é suspeito de um crime? Mandados expedidos sem justa causa, isto é sem especificar o que se deve buscar e sem que a decisão que determina sua expedição seja precedida de perquirição quanto à possibilidade de adoção de meio menos gravoso para chegar-se ao mesmo fim. A polícia é autorizada, largamente, a apreender tudo quanto possa vir a consubstanciar prova de qualquer crime, objeto ou não da investigação. Eis aí o que se pode chamar de autêntica "devassa". ${ }^{101}$

Com efeito, não se pode deixar à discricionariedade da autoridade policial os objetos a serem apreendidos, transformando a ordem em um tipo de expedição de pesca com a finalidade de encontrar qualquer coisa que possa revelar a existência de um crime.

Por isso, e para que o agente que executa o mandado possa identificar as coisas pertinentes à apreensão, é necessário que detenha informações sobre o acontecimento material acerca do qual recai a investigação, ou seja, "é preciso que o mandado especifique a qual fato supostamente criminoso o objeto da apreensão deve estar vinculado". ${ }^{102}$

Ademais, também no que se refere à execução da ordem judicial, a busca surge revestida de formalidades essenciais para sua validade. De fato, procura a lei processual cercar de cautelas e exigências o exercício da medida, indicando que a busca domiciliar

\footnotetext{
${ }^{99}$ Ibid., p.701.

${ }^{100}$ Medidas patrimoniais... op.cit., p.263.

101 BRASIL. Supremo Tribunal Federal. Tribunal Pleno. Habeas Corpus 95.009/SP. Relator Ministro Eros Grau. Julgado em 06/11/2008. DJe 241, divulgado em 18/12/2008, publicado em 19/12/2008. Acórdão disponível em: <http://redir.stf.jus.br/paginadorpub/paginador.jsp?docTP=AC\&docID=570249 >. Acesso em: 09/07/2011.

${ }^{102}$ LEITE, Medidas patrimoniais... op.cit., p.263.
} 
realiza-se, em regra, durante o dia e pela autoridade policial, ou seus agentes, e da seguinte forma, sintetizada por CLEUNICE PITOMBo a partir da leitura do artigo 245 do CPP: (1) leitura e exibição do mandado; (2) intimação para abrir a porta; (3) em caso de desobediência, permite-se o arrombamento; (4) autoriza-se o emprego de força para o descobrimento do que se procura; (5) intima-se o indivíduo para entregar o que se procura; (6) exige-se presença de vizinho, quando ausente o morador; (7) lavra-se, ao final, auto. ${ }^{103}$

Para tratar da figura da apreensão, reporta-se, mais uma vez, às lições de Cleunice Pitombo, que destaca a necessidade de se distinguir as seguintes situações de apossamento: a decorrente de busca profícua, a exibição voluntária, e o encontro casual. ${ }^{104}$

É que a exibição voluntária, por decorrer da apresentação da coisa móvel pelo seu detentor, autoriza a apreensão pela autoridade policial em qualquer momento da investigação, desde que observada, conforme sinaliza a autora, e sob pena de se mostrar arbitrária e inútil, (1) a licitude, ou não, na obtenção da coisa exibida; (2) a necessidade de retirá-la do poder de quem a retém; e (3) a imprescindibilidade, para a instrução criminal, do apossamento.

A apreensão decorrente de procura profícua encontra-se vinculada aos limites constitucionais e processuais da busca, assim se o apossamento resultar de busca ilegal, não possui valor, para a instrução.

Por fim, a possibilidade de proceder à apreensão no encontro casual de coisas e pessoas não relacionadas com o fato investigado, sendo este o ponto que especificamente toca à temática do presente trabalho. $\mathrm{O}$ encontro fortuito, aqui, decorre da busca e apreensão autorizada com base no artigo 243 do Código de Processo Penal, quando, no decorrer da diligência de busca domiciliar, surge a possibilidade de apreender objeto diverso daquele procurado, mas relevante para a comprovação de outro delito.

\subsubsection{Os conhecimentos fortuitos no cumprimento dos mandados de busca e apreensão}

No que se refere à interceptação das comunicações telefônicas, esta é mais problemática, eis que só permitida para crimes punidos com reclusão e, sobretudo, porque

\footnotetext{
${ }^{103}$ Da busca e da apreensão... op.cit., p.209.

${ }^{104}$ Ibid., p.264-271.
} 
sua estrutura técnica permite que não apenas o alvo seja interceptado e gravado, mas também todos que se comunicam com ele ou utilizam a linha telefônica interceptada. $\mathrm{O}$ que não significa que os conhecimentos fortuitos constituam um problema exclusivo deste meio de obtenção de prova.

De fato, e como já antecipado, o problema não é próprio das interceptações, e se projeta também nas medidas de busca e apreensão,

(...) que aun en el caso de que se dirija solo a la detención de un imputado, el acceso al lugar donde se encuentra posibilita la detención de otros elementos desvinculados de la causa como (...) secuestro de elementos delictivos distintos al proprio buscado que se relacionen con otros delitos y también los que se encuentren en el lugar, como drogas, armas, elementos robados, etcétera. ${ }^{105}$

Embora seja meio de obtenção de prova admissível em relação a qualquer crime, a “estrutura legal da busca é extremamente rígida. Recorde-se, aqui, a indispensabilidade, para a sua validade, do preenchimento dos requisitos necessários à expedição e ao conteúdo da ordem de busca, bem como os inerentes à sua execução". ${ }^{106}$

Releva-se aqui a importância da indicação detalhada do motivo e dos fins da diligência (art.243, inc.II, CPP), a que se destina o mandado judicial de busca domiciliar.

Cleunice Pitombo adverte que não se sai em busca de coisa qualquer, pois ela “não surge aleatória, indeterminada ou indeterminável, mas se vincula com o que importa para a originária persecução penal, que ensejou a ordem de busca" ${ }^{107}$ É dizer: a busca possui uma especialidade, ou seja, deve objetivar que a prova, obtida através desse instituto, se destine à comprovação do delito objeto de investigação.

A questão que se coloca é se, encontrada ao acaso, eventualmente, coisa diversa e sem nenhuma relação com o fato perquirido, é possível, na busca originária, apreendê-la? E se a localização casual estiver associada ao contexto que originou a busca?

Assim, por um lado, a possibilidade de proceder à apreensão no encontro de coisas não relacionadas com o fato investigado pode suscitar problemas. Mas por outro, "nem sempre se sabe de antemão o que se vai se encontrar em uma busca domiciliar, não

\footnotetext{
${ }^{105}$ CARBONE, Requisitos constitucionales... op.cit., p. 370.

${ }^{106}$ PITOMBO, Da busca e da apreensão... op.cit., p.266.

${ }^{107}$ Ibid., p.109.
} 
podendo os policiais ignorar informações que interessem à Justiça e que foram localizadas no desenvolvimento de uma investigação formal e regular, exercida com controle e autorização judicial". ${ }^{108}$

Contudo, certo é que as autoridades devem limitar-se a procurar o objetivo, o alvo da medida, respeitando o recato das pessoas e aquilo que não interessa à persecução penal, evitando o varejamento inútil, que estorva, importuna, incomoda os moradores. ${ }^{109}$ Discutese, assim, a licitude ou não da apreensão, em domicílio, de objeto ou documento que não esteja previamente especificado no mandado judicial.

Aliás, o encontro fortuito, no mais das vezes, ocorre por conta da violação à finalidade do procedimento de busca, varejando-se aleatoriamente coisas e documentos que não guardam relação com o objeto investigado, isto é, com aquele delito que legitimou a medida.

EugÊNio PACELli De Oliveira cita o exemplo de um mandado expedido para a busca e apreensão de animais silvestres durante uma investigação de crime contra a fauna, no cumprimento do qual os policiais adentram no domicílio do investigado e passam a revirar gavetas e armários da residência, posicionando-se o autor, nesse caso (em que o local revistado jamais abrigaria o objeto do mandado judicial), pela ilicitude da prova de infração penal desvinculada da autorização judicial. Do contrário, a ação policial "fugiria do controle judicial, configurando verdadeira ilegalidade, por violação do domicílio, no ponto em que, para aquela finalidade, o ingresso na residência não estaria autorizado". ${ }^{110}$

Dessa maneira, merece reflexão o tema do encontro casual, em virtude do cumprimento de mandados de busca e de apreensão domiciliar, sobretudo, quando inexiste correlação entre o conhecimento fortuito e os motivos e fins justificadores da decisão judicial que autorizou a providência restritiva.

Registre-se, desde já, que não se está a pensar na hipótese em que os agentes, durante a busca domiciliar, se deparam com um crime permanente, posto que a apreensão, nas situações de flagrância, dispensa autorização judicial, devendo a autoridade policial apreender os objetos que tiverem relação com o fato criminoso (não que a solução seja tão simples assim, motivo pelo qual se abordará a questão em tópico próprio no ITEM 7.1)

\footnotetext{
${ }^{108}$ LOPES, Fábio Motta. O encontro fortuito de provas durante buscas domiciliares. In: Boletim IBCCRIM, São Paulo, no 220, p. 14-15, março/2011. p.14.

${ }^{109}$ PITOMBO, Da busca e da apreensão... op.cit., p.220.

${ }^{110}$ Curso de Processo Penal... op.cit., p.314.
} 


\subsection{Um parêntese: outros meios de obtenção de prova (a criminalidade organizada)}

Como já antecipado, o tema dos conhecimentos fortuitos encontra eco, majoritariamente, no quadro doutrinal das interceptações telefônicas, e por vezes, é tratado no âmbito das buscas domiciliárias. Mas isso não significa que a figura dos conhecimentos fortuitos esteja atrelada à obtenção de provas somente através desses meios de investigação.

É que outros instrumentos de obtenção de prova no processo penal geram restrições ou limitações a direitos fundamentais, avançando sobre os direitos à privacidade e à intimidade, daí o necessário parêntese sobre outros meios de investigação de prova (em especial aqueles destinados à repressão da criminalidade organizada) cuja inserção no presente capítulo serve, na verdade, para apresentar os motivos pelos quais o presente trabalho tem os olhos voltados à interceptação telefônica e à busca e apreensão, o que já foi sinalizado desde o seu início.

Já se mencionou que o direito fundamental ao sigilo das comunicações telefônicas como expressão da liberdade de manifestação do pensamento e do direito à intimidade é consagrado no artigo $5^{\circ}$, inc. XII, da Constituição Federal, admitindo, indubitavelmente, sua quebra para fins de investigação criminal ou instrução processual penal, nas hipóteses e na forma que a lei estabelecer, por de ordem judicial.

Todavia, o referido inciso, na verdade, garante a inviolabilidade de quatro liberdades que dizem respeito à comunicação entre as pessoas ${ }^{111}$, por diversos meios: correspondência; comunicação telegráfica; comunicação de dados; comunicação telefônica.

O mandamento constitucional assim se ostenta:

\footnotetext{
111 TÉRCIO SAMPAIO FERRAZ JR ensina que o sigilo, no inciso XII do art.5 ${ }^{\circ}$, está referido à liberdade de comunicação entre os indivíduos, por diversos meios, no interesse da defesa da privacidade: "Obviamente o que se regula é comunicação por correspondência e telegrafia, comunicação de dados e telefonia. O que fere a liberdade de omitir pensamento é, pois, entrar na comunicação alheia, fazendo com que o que devia ficar entre sujeitos que se comunicam privadamente passe ilegitimamente ao domínio de um terceiro." (Sigilo de dados: o direito à privacidade e os limites à função fiscalizadora do Estado. In: Revista da Faculdade de Direito da Universidade de São Paulo. São Paulo, v.88, p.439-459, 1993. p.446). Ainda que haja divergência sobre a referência a "dados", prevalece corretamente a posição de que o art.5\%, inc. XII, CF trata da inviolabilidade de comunicação de dados, e não do sigilo do banco de dados, de modo que, se os dados em si estiverem relacionados à intimidade ou vida privada, nesse caso merecem proteção porque tutelados pelo art. $5^{\circ}$, inc. $\mathrm{X}, \mathrm{CF}$.
} 
XII - é inviolável o sigilo da correspondência e das comunicações telegráficas, de dados e das comunicações telefônicas, salvo, no último caso, por ordem judicial, nas hipóteses e na forma que a lei estabelecer para fins de investigação criminal ou instrução processual penal; (sem grifos no original)

A Lei nº 9.296/96 surgiu, como a própria já enuncia, destinada a regulamentar a parte final do dispositivo acima transcrito, destacando já no seu artigo $1^{\circ}$ que ela se aplica à interceptação de comunicações telefônicas para prova em investigação criminal e em instrução processual penal. Mas, conforme o parágrafo único do artigo $1^{\circ}$, "o disposto nesta Lei aplica-se à interceptação do fluxo de comunicações em sistemas de informática e telemática".

Consoante definição encontrada no Novo Dicionário da Língua Portuguesa, a informática tem por objeto o "tratamento da informação através do uso de equipamentos e procedimentos da área de processamento de dados". ${ }^{112} \mathrm{E}$, a telemática versa sobre a "manipulação e utilização da informação através do uso combinado de computador e meios de telecomunicação"113, e nesse caso, o fluxo de comunicações que estaria sujeito à interceptação seria, portanto, todo e qualquer dado transmitido por meio de referida tecnologia, como ocorre, por exemplo, com a transmissão de dados via modem ou facsímile e a comunicação via internet.

Não obstante a existência de previsão legal sobre a possibilidade de interceptação do fluxo de informações em sistemas de informática e telemática, no parágrafo único do artigo $1^{\circ}$ da Lei $n^{\circ} 9.296 / 96$, como meio de obtenção de prova, há divergência quanto à constitucionalidade desse dispositivo, já que esse fluxo de informação ocorre por intermédio da comunicação de dados.

A dúvida suscitada (inexistente com relação às comunicações telefônicas) e que gera divergência no entendimento quanto à constitucionalidade de referido dispositivo tem origem na própria interpretação gramatical do artigo $5^{\circ}$, inc. XII, CF, em especial sobre o alcance da expressão no último caso.

Parece prevalecer o entendimento segundo o qual a exceção ao sigilo abrange apenas as comunicações telefônicas, com a consequente inconstitucionalidade do parágrafo

112 Informática. In: FERREIRA, Aurélio Buarque de Holanda. Novo Dicionário da Língua Portuguesa. 2.ed. Rio de Janeiro: Editora Nova Fronteira, 1986. p.945.

${ }^{113}$ Telemática [tele(comunicação) + (infor)mática]. Ibid., p.1.658. 
único do artigo $1^{\text {o }}$ da Lei $\mathrm{n}^{\circ} 9.296 / 96^{114}$, de modo que as informações colhidas pela interceptação do fluxo de comunicações em sistemas de informática e telemática representam prova ilicitamente obtida e, portanto, inadmissível. Fugiria, assim, à problemática do presente trabalho, pois se estabeleceu a premissa de que preenchem o quadro dos conhecimentos fortuitos os fatos recolhidos por meio da realização legal de um meio de obtenção de prova. De fato, na delimitação do tema, a obtenção de conhecimentos fortuitos é precedida de um procedimento lícito.

Obviamente, quem considera que a ressalva constitucional da parte final do inc. II do art. $5^{\circ}$ da Constituição Federal, se estende às comunicações de dados (ou então que em nome da relatividade de todos os direitos fundamentais inexiste inconstitucionalidade da norma prevista no parágrafo único do artigo $1^{\circ}$ da Lei $\left.n^{\circ} 9.296 / 96\right)^{115}$, terá de concluir pela

${ }^{114}$ VICENTE GRECO FILHO afirma ser inconstitucional o dispositivo, pois a expressão no último caso refere-se apenas às comunicações telefônicas. Segundo o autor, "não se trata, aqui, de se aventar a possível conveniência de se fazer interceptação nesses sistemas, mas sim de interpretar a Constituição e os limites por ela estabelecidos à quebra do sigilo" (Interceptação telefônica... op.cit., p.18). SERGIO PITOMBO enfatiza que "É relativo o sigilo, tão-só, das comunicações telefônicas. Ao que se depreende, o sistema de informática e de telemática, protegido, em razão de seu conteúdo, pelo sigilo das comunicações, não se pode interceptar. (...) A inconstitucionalidade emerge manifesta" (Sigilo nas comunicações... op.cit., p. 07-08). TORQUATO AVOLIO também conclui pela inconstitucionalidade do parágrafo único do artigo $1^{\circ}$ da Lei $n^{\circ} 9.296 / 96$, pois, nos termos da Constituição, as comunicações de dados não são passíveis de interceptação. (Provas ilícitas... op.cit., p.224). Ainda nesse sentido: “(...) como as regras limitadoras de direitos, sobretudo quando excepcionais, devem ser interpretadas restritivamente, poderia afirmar-se que a previsão de interceptação do fluxo de comunicações, tanto pela informática como pela telemática, é inconstitucional". (GRINOVER; FERNANDES; GOMES FILHO, As nulidades... op.cit., p.171).

${ }^{115}$ LENIO LUIZ STRECK destaca que não vislumbra inconstitucionalidade no parágrafo único do artigo $1^{\circ}$ da Lei $\mathrm{n}^{\circ}$ 9.296/96. (As interceptações telefônicas e os Direitos Fundamentais. Porto Alegre: Livraria do Advogado, 2001. p.42). No mesmo sentido, CESAR DARIO MARIANO DA SILVA. (Provas ilícitas: princípio da proporcionalidade, interceptação e gravação telefônica, busca e apreensão, sigilo e segredo, confissão, comissão parlamentar de inquérito (CPI) e sigilo. 6.ed. São Paulo: Atlas, 2010. p.46). PAULO RANGEL interpreta o dispositivo constitucional dividido em dois grupos: (i) sigilo da correspondência e das comunicações telegráficas e (ii) de dados e das comunicações telefônicas. E conclui: “Assim, a expressão último caso açambarcaria dados e comunicações telefônicas" (Breves considerações sobre a Lei n 9.296/96: interceptação telefônica. In: Revista Brasileira de Ciências Criminais, São Paulo, no 26, p.143-151. abrjun/1999. p.143). Para André Augusto Mendes Machado e Andre PIRES DE AndradE KeHDI, a expressão no último caso também abrange os dados e as comunicações telefônicas. (Sigilo das comunicações e de dados. In: FERNANDES, Antonio Scarance; ALMEIDA, José Raul Gavião de; MORAES, Mauricio Zanoide de (Coords.). Sigilo no processo penal: eficiência e garantismo. São Paulo: Revista dos Tribunais, 2008. p.243-244).

Ainda que, vislumbrando que a exceção constitucional refira-se somente à interceptação telefônica, ALEXANDRE DE MORAES entende que, como nenhuma liberdade individual é absoluta, inexiste

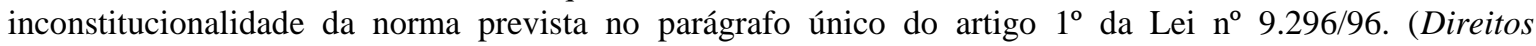
humanos... op.cit., p.150-152). No mesmo sentido, Eugenio PACElli DE Oliveira (Curso de Processo Penal... op.cit., p. 303). GERALDO PRADO entende que, diante da evolução da tecnologia, "quando os dados informáticos repousarem em bancos de dados, a sua comunicação não poderá ser objeto de interceptação, pois assim estaria sendo violada a Constituição. Porém, interpretada sistemática e teleologicamente, não haverá contraste com a norma de garantia a interceptação (...) quando se tratar de dados transmissíveis de modo a não repousarem em banco de dados ou forma similar, que permita a apreensão." (Limite às interceptações (2006)... op.cit., p.73). GUSTAVO BADARÓ, concordando com GERALDO PRADO, propõe que se considere constitucional o parágrafo único do artigo $1^{\circ}$ da Lei $\mathrm{n}^{\circ} 9.296 / 96$, "na parte em que permite a interceptação de comunicação de dados por sistema telemático, desde que se trate de dados que não 
possibilidade de quebra de seu sigilo e pela licitude de sua interceptação, para fins de investigação criminal ou instrução processual penal.

Mas, desde que através de ordem judicial e obedecendo-se aos requisitos e procedimentos previstos na legislação regulamentadora (Lei $n^{\circ}$ 9.296/96), formalidades estas que devem ser seguidas a fim de conferir legitimidade constitucional a tal medida excepcional, de modo que os conhecimentos fortuitos decorrentes da interceptação do fluxo de comunicações em sistemas de informática e telemática seguiriam as mesmas observações e conclusões acerca dos conhecimentos obtidos a partir de uma interceptação das comunicações telefônicas.

Embora a Lei $n^{\circ}$ 9.296/96 não seja voltada especificamente para a apuração da criminalidade organizada, regulamentou a quebra do sigilo das comunicações telefônicas e do fluxo de comunicações em sistemas de informática e telemática, meios eletrônicos de captação da prova considerados modernos e eficientes na apuração do crime organizado. Ora, se a tecnologia revolucionou a forma de lidar com o mundo, bem por isso, exige que se repense também o processo penal, já que é impossível ignorar, sob a perspectiva jurídica, a evolução científica.

Assim, é em virtude das inovações da sociedade que se constata a necessidade de utilização de meios tecnológicos avançados na obtenção da prova, com a utilização de novos instrumentos de investigação considerados mecanismos essenciais para descobrir as fontes de prova, sobretudo no combate à chamada criminalidade organizada, na busca de maior eficiência penal. ${ }^{116}$ SCARANCE FERNANDES adverte, entretanto, que atingir o equilíbrio entre a repressão ao crime organizado e as garantias fundamentais do devido processo penal é um dos grandes desafios contemporâneos:

O campo mais problemático para o legislador e para a doutrina, na atualidade, é o da criminalidade grave ou organizada, em que as soluções e propostas são as mais variáveis. Têm os países dificuldade em criar um corpo legislativo que, permitindo eficiência ao sistema repressivo, não fira os direitos e garantias dos indivíduos, assegurados nas Constituições e Convenções de Direitos Humanos. Se, de um lado, o crime violento ou organizado cresce assustadoramente, alastrando o medo e a insegurança

permaneçam armazenados em bancos de dados, sendo impossível sua apreensão”. (Direito Processual Penal... op.cit., p.284).

${ }^{116} \mathrm{Na}$ observação de CESAR DARIO MARIANO DA SILVA: “A criminalidade organizada está a reclamar um combate eficaz através de meios modernos". (Provas ilícitas... op.cit., p.45). 
entre os cidadãos, de outro são trazidas propostas perigosas que representam risco de graves supressões das garantias individuais. ${ }^{117}$

Essa dificuldade observada pelo autor fica evidente na Lei 9.034/95, que dispõe sobre a utilização de meios operacionais para a prevenção e repressão de ações praticadas por organizações criminosas. Trata-se de estatuto legal que instituiu alguns meios específicos de investigação por intermédio de canais que restringem direitos fundamentais, do investigado e inclusive de terceiros: "instrumentos modernos de investigação que atingem igualmente pessoas que não são suspeitas". ${ }^{118}$ Esta tônica é importante para reconhecer a necessidade de uma legislação completa que regulamente a utilização desses meios de obtenção de prova, com a finalidade de demarcar seus limites. No entanto, o que se percebe da Lei $n^{\circ}$ 9.034/95 não é isso.

Prevê a Lei do crime organizado a possibilidade de "acesso a dados, documentos e informações fiscais, bancárias, financeiras e eleitorais" (art.2 ${ }^{\circ}$, inc.III, da Lei $\mathrm{n}^{\circ}$ $9.034 / 1995)^{119}$ em qualquer fase de persecução criminal.

Face à importância do meio de pesquisa de prova, bastante comum na elucidação de crimes cometidos por organizações criminosas, melhor seria que a legislação brasileira demonstrasse maior interesse pelo tema, disciplinando um procedimento específico para

117 O equilíbrio entre a eficiência e o garantismo e o crime organizado. In: Revista Brasileira de Ciências Criminais. São Paulo, no 70, p.229-268, jan-fev/2008. p.232.

${ }^{118}$ O Prof. da Universidade de Frankfurt WINFRIED HASSEMER, bem destacou: "As reformas do processo penal concentram-se nas ultimas décadas na fase de investigação, isto é, naquela parte do processo em que se trata de instrumentos de controlo. Refiro-me por exemplo à observação policial, à busca através de cruzamento de dados pessoais, às escutas telefónicas, às escutas secretas em habitações, às informações de serviços secretos para a polícia, aos agentes infiltrados, que são os modernos instrumentos de investigação do processo penal alemão nos últimos anos. Surgem aqui dois problemas. Primeiro, estes instrumentos de averiguação têm de ser secretos, pois se o visado nota que está a ser investigado não funcionam. São diferentes dos instrumentos processuais penais clássicos das buscas, do confisco, do exame em hospital psiquiátrico, da prisão preventiva. Isto significa que temos um novo elemento, o elemento da latência (...) Eu não quero criticar esta solução mas apenas precisar que se trata de algo que modifica intensamente a tradição clássica do processo penal. Em segundo lugar, estes instrumentos atingem necessariamente terceiras pessoas. Agentes infiltrados, escutas telefónicas, cruzamento de dados, observação policial afectam não só os suspeitos mas também o seu círculo de relações. (...) Nos ordenamentos jurídicos europeus o visado presumese inocente na fase de investigação. No entanto, ele tem de tolerar os encargos próprios desta fase, como a prisão preventiva, ou a observação policial, com base num fundamento jurídico: a suspeita. Esta funciona como equivalente funcional da culpa antes da condenação do arguido, o que a torna um conceito muito importante. Ora, e é isto que eu quero dizer, estes instrumentos modernos de investigação atingem igualmente pessoas que não são suspeitas." (Processo Penal e direitos fundamentais. Transcrição da intervenção oral pelo Goethe-Institut Lissabon; tradução da conferência para língua portuguesa por Augusto Silva Dias. In: Jornadas de Direito Processual Penal e Direitos Fundamentais. Organização Faculdade de Direito de Lisboa e Conselho Distrital de Lisboa da Ordem dos Advogados. Coordenação científica de Maria Fernanda Palma. Coimbra: Almedina, 2004. p.21-22.)

119 “Art. 2- Em qualquer fase de persecução criminal são permitidos, sem prejuízo dos já previstos em lei, os seguintes procedimentos de investigação e formação de provas: (...) III - o acesso a dados, documentos e informações fiscais, bancárias, financeiras e eleitorais." 
sua utilização, pois acesso a informações fiscais, bancárias e financeiras nada mais é do que quebra de sigilo de dados, e ainda que não haja proteção específica na Constituição Federal, entende-se que estão amparados pelo art. $5^{\circ}$, inc. X, que declara a inviolabilidade da vida privada.

Mesmo que outros textos legais já autorizassem a quebra desses sigilos para investigação ou processo criminal, e embora se trate de medida que toca a privacidade, o legislador nacional nunca lhe dispensou tratamento adequado. ${ }^{120}$

Posteriormente, a Lei $\mathrm{n}^{\mathrm{o}}$ 10.217/2001 acrescentou novos "procedimentos de investigação e formação de provas" na Lei do crime organizado: a captação e interceptação ambiental de sinais eletromagnéticos, óticos ou acústicos (art.2 $2^{\circ}$, inc. IV da Lei $\mathrm{n}^{\circ}$ 9.034/95) e a infiltração policial (art. $2^{\circ}$, inc.V,). ${ }^{121}$

Assim, dentre os procedimentos de investigação permitidos para a apuração de crimes decorrentes de ações praticadas por organizações criminosas, pela Lei $\mathrm{n}^{\circ}$ 10.217/2001, nominou-se a possibilidade de captação e interceptação ambiental de sinais eletromagnéticos, óticos ou acústicos, bem como seu registro e análise, "mediante circunstanciada autorização judicial" (art. $2^{\circ}$, inc. IV da Lei no 9.034/95). Está-se aqui se referindo à captação sub-reptícia da conversa (registro de voz e/ou imagem) entre presentes, efetuada por um terceiro, dentro do ambiente onde se situam os interlocutores, com o desconhecimento destes. É a chamada interceptação entre presentes, ou

\footnotetext{
${ }^{120}$ Com relação ao sigilo financeiro, por exemplo, nota-se que a Lei Complementar 105/2001, embora regulamentando a matéria, "foi omissa na disciplina de diversos pontos importantes sobre o tema (legitimidade para requerimento, requisitos para o deferimento, procedimento a ser observado etc.)". (SILVA, Eduardo Araújo da. Crime organizado: procedimento probatório. São Paulo: Atlas, 2003. p.107). Ademais, não há qualquer restrição no que toca à sua quebra, que pode ser decretada "quando necessária para apuração de ocorrência de qualquer ilícito, em qualquer fase do inquérito ou do processo judicial, e especialmente nos seguintes crimes (...)." (art. $1^{\circ}, \S 4^{\circ}$, LC 105/2001). Como lembra JulianA GARCIA BELLOQUE, o rol de crimes trazido pela disposição legal é meramente exemplificativo, havendo a ressalva de que a quebra de sigilo deve ser utilizada especialmente para a apuração das infrações ali numeradas. E que em respeito ao critério da proporcionalidade, reitor da restrição a direitos fundamentais, o rol deveria ser taxativo, "pois, em se tratando de compressão do sigilo financeiro, da lei exigem-se preceitos inequívocos e precisos, que descrevam as específicas e excepcionais situações de cabimento da medida restritiva (...)". (Sigilo bancário: análise crítica da LC 105/2001. São Paulo: Revista dos Tribunais, 2003. p.94-95).

121 “Art. $2^{\underline{0}}(\ldots)$

IV - a captação e a interceptação ambiental de sinais eletromagnéticos, óticos ou acústicos, e o seu registro e análise, mediante circunstanciada autorização judicial; (Inciso incluído pela Lei $\mathrm{n}^{\circ}$ 10.217, de 11.4.2001)

$\mathrm{V}$ - infiltração por agentes de polícia ou de inteligência, em tarefas de investigação, constituída pelos órgãos especializados pertinentes, mediante circunstanciada autorização judicial. (Inciso incluído pela Lei no 10.217 , de 11.4.2001)

Parágrafo único. A autorização judicial será estritamente sigilosa e permanecerá nesta condição enquanto perdurar a infiltração". (Parágrafo incluído pela Lei n 10.217, de 11.4.2001)
} 
interceptação ambiental ${ }^{122}$, meio de obtenção de prova que, restringindo direitos fundamentais, visa à descoberta de fontes de prova de forma insidiosa, através de instrumentos normalmente inseridos nos espaços mais recônditos da intimidade e da vida privada $\left(\operatorname{art} .5^{\circ} \text {, inc. } \mathrm{X}, \mathrm{CF}\right)^{123}$.

Isso justifica que a técnica investigativa, também conhecida como vigilância eletrônica, necessite de um procedimento probatório previsto e delimitado em lei que discipline a matéria ${ }^{124}$, inclusive quanto aos seus requisitos, sem o que é difícil até de se cumprir a exigida circunstanciada autorização judicial. Por isso, com razão, SCARANCE FERNANDES afirma ser

(...) desarrazoado permitir que, com a amplitude do art. $2^{\circ}$, sejam instalados microfones ou outros artefatos em residências e em outros locais de uso particular para gravar vozes e imagens, com a captação de diálogos e a filmagem de pessoas e seus atos. Cuida-se de grave restrição que, se eventualmente admitida, deverá estar cercada de maiores cuidados. Não basta, para esse fim, a previsão de autorização judicial, como consta da lei. ${ }^{125}$

De fato, no direito processual penal brasileiro, da forma como colocada pela Lei $n^{\circ}$ 9.034/95, a interceptação de comunicação entre presentes é um meio de obtenção de prova atípico $^{126}$, o que decorre de sua mera enunciação no art. $2^{\circ}$, inc. IV, desacompanhada das regras legais do procedimento probatório.

\footnotetext{
${ }^{122}$ Quando a interceptação de conversa entre presentes, realizada por terceiro, se faz com o conhecimento de algum dos interlocutores, denomina-se escuta ambiental, guardando assim afinidade terminológica com as modalidades de interceptação e escuta telefônica mencionadas no ITEM 3.1.1. Não há que se confundir qualquer destas com as gravações clandestinas, entendidas como aquelas registradas por um de seus interlocutores, sem o conhecimento dos demais, e que não são objeto do presente estudo.

${ }^{123}$ A abordagem que se faz é sob a perspectiva da interceptação em locais privados ou públicos com expectativa de privacidade, já que se as pessoas presentes estão em um espaço público, não gozam de uma especial proteção da intimidade.

${ }^{124}$ TORQUATO AVOLIO destaca que o ordenamento italiano se caracteriza por ser atento a essa necessidade, “Conquanto na Itália já constituam as interceptações ambientais, desde 1988, objeto de regulamentação no processo penal, verifica-se que sua a disciplina não serviu de paradigma para o nosso sistema processual penal". (Provas ilícitas... op.cit., p.274). No mesmo sentido, EdUARdo ARAUJO DA SiLvA chega a lamentar que, apesar da interceptação ambiental ser tida como meio para a obtenção da prova que implica limitação do direito à intimidade, à vida privada e à imagem do investigado, o legislador brasileiro "limitou-se a exigir prévia e motivada decisão judicial para seu deferimento, contrariando a tendência verificada no plano internacional de se exigir formas claras de controle em relação à utilização indiscriminada da vigilância eletrônica". (Crime organizado... op.cit., p.105).

${ }^{125}$ O equilíbrio entre a eficiência e o garantismo... op.cit., p. 250.

${ }^{126}$ Leva-se em conta a posição ampliativa do conceito de atipicidade, segundo a qual uma prova é atípica em duas situações: “1) quando ela seja prevista no ordenamento, mas não o seja seu procedimento probatório; 2)
} 
E essa atipicidade é um obstáculo para a análise dos conhecimentos fortuitos nas interceptações ambientais, pois a falta de regulamentação procedimental impede que se estabeleçam claramente os parâmetros limitativos da licitude probatória.

Veja-se que, diferentemente do que fez a Lei $n^{\circ}$ 9.296/96, que regulamenta as interceptações telefônicas e telemáticas, dispondo sobre os necessários fundamentos da autorização judicial e delimitando prazos e duração da medida, sua forma de execução, alcance e limites ${ }^{127}$, a Lei do crime organizado limita-se a enunciar a possibilidade de interceptação ambiental como procedimento investigatório, ausente qualquer delimitação legal de seus requisitos e previsão procedimental da medida ${ }^{128}$.

Outro instrumento legal que possibilita a restrição à privacidade, também incluída na Lei $n^{\circ} 9.034 / 95$ a partir das modificações nela inseridas pela Lei $n^{\circ} 10.217 / 2001$, é a possibilidade de infiltração de agentes em tarefas de investigação para a apuração de crimes decorrentes de ações praticadas por organizações criminosas, "mediante circunstanciada autorização judicial”, norma que trouxe para o ordenamento jurídico pátrio a figura do agente infiltrado (art. $2^{\circ}$, inc.V, da Lei $\left.n^{\circ} 9.034 / 1995\right)$.

Depois, em matéria de crimes envolvendo tráfico de drogas, seguindo a mesma trilha, a Lei $\mathrm{n}^{\mathrm{o}}$ 11.343/2006 também nominou a infiltração de agentes como procedimento investigatório quando pertinente aos crimes ali previstos, "mediante autorização judicial e ouvido o Ministério Público" (art.53, inc. I) ${ }^{129}$.

quando nem ela nem seu procedimento probatório sejam previstos em lei." (DEZEM, Da prova penal... op.cit., p.147).

${ }^{127}$ A Lei 9.296/96 inclusive prevê consequências penais para a realização de interceptação sem autorização judicial ou com objetivos não autorizados em lei:

"Art.10. Constitui crime realizar interceptação de comunicações telefônicas, de informática ou telemática, ou quebrar segredo da Justiça, sem autorização judicial ou com objetivos não autorizados em lei.

Pena: reclusão, de dois a quatro anos, e multa".

${ }^{128}$ Alguns autores chegam a sugerir a possibilidade de utilização do procedimento probatório previsto na Lei $\mathrm{n}^{\circ}$ 9.296/96, de maneira analógica. Nesse sentido: FÁBIO RAMAZZINI BECHARA e GUILHERME MADEIRA DEZEM. (Captação ambiental de imagens: uso e limites. In: Estudos de processo penal. INSTITUTO DE ESTUDOS AVANÇADOS DE PROCESSO PENAL - ASF. São Paulo: Scortecci, 2011. p.116-140. Disponível em: 〈http://www.institutoasf.com.br/dcms/uploads/arquivo 07112011003518.pdf〉. Acesso em: 12/10/2012. p.126). E outros sustentam sua inconstitucionalidade: para EDUARDO ARAÚJO DA SILVA a interceptação ambiental é medida inconstitucional, pois carece de prévia permissão constitucional, já que o art. $5^{\circ}$, XII, CF, só admite a violação das comunicações telefônicas (Crime organizado... op.cit., p.104), com o que concorda MARIO SERgio Sobrinho (O crime organizado no Brasil. In: FERNANDES, Antonio Scarance; ALMEIDA, José Raul Gavião de; MORAES, Mauricio Zanoide de (Coords.). Crime organizado: aspectos processuais. São Paulo: Revista dos Tribunais, 2009. p.46).

129 "Art. 53. Em qualquer fase da persecução criminal relativa aos crimes previstos nesta Lei, são permitidos, além dos previstos em lei, mediante autorização judicial e ouvido o Ministério Público, os seguintes procedimentos investigatórios: I - a infiltração por agentes de polícia, em tarefas de investigação, constituída pelos órgãos especializados pertinentes." 
Entretanto, o que se observa nas citadas leis é que, para além de indicar obrigatoriedade de a medida ser ordenada judicialmente (sem nada prever sobre os requisitos a serem observados para a autorização) e estabelecer que esta será estritamente sigilosa enquanto durar a infiltração, merece crítica, em especial, a ausência de qualquer previsão procedimental para a atuação do agente infiltrado, daí falar-se também aqui em meio de obtenção de prova atípico.

Oportuno observar que o agente infiltrado atua de forma oculta, ingressando na organização, inclusive podendo vir a participar da vida privada de outras pessoas nem sempre ligadas às atividades delituosas. Importante, por isso, que a sua atuação seja regulada, como fazem outras legislações no âmbito internacional. Com efeito, MARIÂNGEla TOMÉ LOPES, lembrando que se trata de um meio extraordinário de investigação e que, portanto, exige para sua utilização uma legislação específica e completa que normatize toda a atuação do agente (a exemplo da legislação espanhola), destaca:

As duas leis brasileiras que tratam do agente infiltrado fazem-no em apenas dois incisos, deixando de regulamentar diversos aspectos imprescindíveis e dificultando a utilização dessa figura no Direito brasileiro.

Sendo assim, faz-se necessária uma legislação completa que regulamente o agente infiltrado, pois se trata de uma atividade que ofende diversas garantias constitucionais. Portanto, precisa estar bem regulamentada.

A necessidade de leis regulamentadoras para a atividade do agente infiltrado tem por finalidade demarcar os vértices da investigação criminal a fim de evitar possíveis abusos da atuação policial. ${ }^{130}$

No mesmo sentido, enfatizando que essa atipicidade procedimental representa verdadeira violação à licitude probatória, MAURICIO ZANOIDE DE MORAES afirma que "O mais delicado e invasivo meio de obtenção de prova ('agente infiltrado') não pode ser aceito e colocado em operação sem qualquer regulamentação que protegesse o agente envolvido e regulasse seus limites de atuação". ${ }^{131}$

\footnotetext{
${ }^{130}$ A infiltração de agentes no Brasil e na Espanha: possibilidade de reformulação do sistema brasileiro com base no direito espanhol. In: Revista Brasileira de Ciências Criminais, São Paulo, nº 89. p.495-532, mar.abr./2011. p.519.

${ }^{131}$ Entre Prometeu e Cassandra, o IBCCRIM continua como bastião mais altivo e lúcido contra as violações constitucionais. In: Boletim IBCCRIM. São Paulo, ed. especial 20 anos, p.05-06, agosto/2012. p.5. Oportuna a observação de ANTONIO SCARANCE FERNANDES: "Para ser adotada, a infiltração policial deve ser precedida de uma legislação minuciosa, que, além de exigir prévia e fundamentada autorização do juiz após oitiva do
} 
Ao realizar um estudo comparativo dos sistemas processuais penais português e brasileiro, sob a ótica da tipicidade processual como requisito da admissibilidade desse meio de obtenção de prova, RenAto STANZiOla VIEIRA menciona que o ordenamento lusitano prevê em enumeração taxativa um catálogo de crimes no âmbito dos quais o recurso à figura do agente infiltrado é legalmente admissível. Também destaca o autor que a lei portuguesa que rege a matéria trabalha com rígidos prazos procedimentais e limites de atuação do agente no plano dos requisitos da medida, chamando atenção para o fato de que nenhuma dessas preocupações é o que se vê no panorama brasileiro. ${ }^{132}$

Com efeito, não há qualquer delimitação legal sobre a mera nomeação da possibilidade de infiltração nas duas leis nacionais acima citadas, de modo que, sem procedimento que impeça autorizações em branco dadas pelo juiz, considerando tamanho potencial lesivo desse meio de obtenção de prova ${ }^{133}$, concorda-se com o autor quando conclui que "enquanto não houver previsão procedimental da figura (...) a norma que lhe dá suporte não tem eficácia jurídica; e dela não decorre obtenção de informações que possam ser admitidas no processo". ${ }^{134}$

Esse contexto sugere que também não se debruce, nesse momento, sobre os conhecimentos fortuitos obtidos pelo agente infiltrado, mas que se espere o advento de nova normatização que discipline esse excepcional meio de obtenção de prova para sua necessária adequação ao contexto das garantias individuais postas na Constituição Federal. “Ora, como é o próprio Estado que estará inserido nas ações criminosas, é preciso que se estabeleçam os limites de tal inserção, para que se saiba, com um mínimo de certeza possível, a fronteira que irá separar a ação lícita da ilícita". ${ }^{135}$

\footnotetext{
Ministério Público, deve especificar os requisitos exigidos para a sua efetivação, os limites da ação do agente infiltrado, o acompanhamento de suas atividades por autoridades superiores." (O equilíbrio na repressão ao crime organizado. In ___ ALMEIDA, José Raul Gavião de; MORAES, Mauricio Zanoide de (Coords.). Crime organizado: aspectos processuais. São Paulo: Revista dos Tribunais, 2009. p.18-19).

${ }^{132}$ Agente infiltrado - um estudo comparativo dos sistemas processuais penais português e brasileiro (ou a imprescindibilidade da tipicidade processual como requisito da admissibilidade dos meios de pesquisa de prova em processo penal. In: Revista Brasileira de Ciências Criminais, São Paulo, nº 87, p.188-231, nov.dez./2010. p.210-214.

${ }^{133}$ Ainda que alguns autores sugiram a aplicação analógica da Lei 9.296/96, como, por exemplo, MARIO SERGIO SOBRINHO ( $O$ crime organizado... op.cit., p.45), preocupa a potencialidade danosa decorrente do seu uso sem regras próprias pré-estabelecidas em lei, pois, na observação de MANUEL Augusto MeIREIS, citado por RENATO STANZIOla VIERA: “(...) no processo de infiltração, o agente infiltrado leva o suspeito a, involuntariamente, produzir prova contra si próprio o que ofende a liberdade de declaração e a garantia da não autoincriminação; além disso, e como vimos, fá-lo entrando na sua vida privada, nas suas relações de amizade, nos seus momentos menos públicos, na sua casa e, eventualmente, no seio da sua família e tudo sem revelar a sua identidade e qualidade." (Agente infiltrado... op.cit., p.214).

${ }^{134}$ VIEIRA, Renato Stanziola. Agente infiltrado... op.cit., p.227.

${ }^{135}$ OLIVEIRA, Curso de Processo Penal... op.cit., p.300.
} 
Não que se seja contrário à edição de leis que instituam meios de investigação de prova mais eficazes (admitidos em caráter excepcional e de forma subsidiária), sobretudo contra a criminalidade organizada, pelo contrário, mas a tipicidade processual é o mínimo que se deve exigir, conforme ensina SCARANCE FERNANDES:

A lei deve: a) regular e explicitar claramente a medida excepcional de obtenção ou produção de prova, com os requisitos necessários para atuála; b) indicar o procedimento a ser seguido; c) especificar os órgãos, entidades ou pessoas legitimadas a requerê-la e a efetivá-la concretamente; d) indicar a autoridade competente para autorizá-la e a motivação necessária na decisão a ser proferida. ${ }^{136}$

Ora, os meios de obtenção de prova são canais que restringem direitos fundamentais, e esta tônica é importante para que sejam demarcados seus vértices. Aliás, essa delimitação legal da fronteira da licitude probatória dos meios excepcionais é essencial para a análise da problemática de que trata o presente trabalho, já que, como delineado no capítulo anterior, as provas obtidas sem observância dos requisitos do meio de investigação de prova escapam ao conceito de conhecimentos fortuitos.

Partindo desta situação do Direito positivo pátrio, dada a deficiente regulação da matéria é que se justifica que o presente trabalho tenha os olhos voltados à interceptação telefônica e à busca e apreensão.

Acrescente-se a tudo o que até aqui foi dito neste tópico a constatação de que a inviolabilidade do domicílio e das comunicações telefônicas são, ainda hoje em dia, as manifestações da intimidade e privacidade mais frequentemente atingidas pelas autoridades responsáveis pela persecução penal.

Aliás, é sob o enfoque dos crimes econômicos que o tema da ilegalidade e abusividade nesses meios de obtenção de prova (interceptação telefônica e busca e apreensão) ganha atualidade, quando se percebe que a atuação conjunta entre a Polícia Federal, a Receita Federal e o Ministério Público Federal tem deflagrado operações de repercussão nacional e internacional no combate à criminalidade organizada, em especial a de matiz econômica, já que, em geral, nessas operações são executados mandados judiciais de busca e apreensão em residências, empresas, depósitos de mercadorias etc.

\footnotetext{
${ }^{136}$ O equilíbrio entre a eficiência e o garantismo... op.cit., p.238.
} 
Preocupa, sobretudo, com relação às interceptações das comunicações telefônicas, medida cuja excepcionalidade está muito longe de existir, posto que extremamente banalizada $^{137}$ a ponto de primeiro haver a interceptação e depois a investigação. É a tal vulgarização mencionada por MANUEL MonTEIRO GUEDES VALENTE já em 2004:

“(...) a desmedida e facilitada autorização das escutas telefónicas - de necessidade duvidosa -, sem que primeiramente se avaliem os meios menos delatores dos direitos e liberdades pessoais, converteu um meio de obtenção de prova de ultima ratio - de exceção - em prima ratio - em vulgar. Da excepcionalidade da escuta telefónica - cuja preservação de direitos fundamentais de terceiros inocentes ou insuspeitos é colocada à mercê do órgão de polícia criminal (OPC) - assiste-se, hoje, à sua vulgarização (...)" 138

${ }^{137}$ Segundo dados publicados no portal de notícias do Conselho Nacional de Justiça, pelo menos 18.050 linhas telefônicas foram monitoradas por decisão da Justiça, em outubro de 2011. (BRASIL. Conselho Nacional de Justiça. Notícias. Mais de 18 mil telefones monitorados em outubro de 2011. Disponível em: <http://www.cnj.jus.br/noticias/cnj/17795-justica-autoriza-grampo-em-195-mil-telefones-em-2011〉. Acesso em: 15/04/2012). Em outubro de 2010, a quantidade de linhas telefônicas monitoradas como resultado de decisões judiciais em ações criminais chegou a 20 mil. (BRASIL. Conselho Nacional de Justiça. Notícias. Brasil teve 20 mil linhas telefônicas monitoradas em 2010. Disponível em: $\langle$ http://www.cnj.jus.br/noticias/10671:brasil-teve-20-mil-linhas-telefonicas-monitoradas-em-2010>. Acesso em: 15/04/2012). O Sistema Nacional de Interceptações Telefônicas, em cujos dados se baseiam os levantamentos, é alimentado a partir das informações prestadas mensalmente pelos Juízos investidos de competência criminal ao CNJ, que coordena o sistema e passa a concentrar as informações de forma sistematizada. Esse controle das interceptações começou a ser feito em setembro de 2008, depois da CPI dos Grampos.

${ }^{138}$ Escutas telefônicas: da excepcionalidade à vulgaridade. Coimbra: Almedina, 2004. p.13. 
SEGUNDA PARTE: EM BUSCA DE UM CRITÉRIO SUSCETÍVEL DE DETERMINAR O ÂMBITO DE ADMISSIBILIDADE DOS CONHECIMENTOS FORTUITOS 


\section{O TRATAMENTO DOS CONHECIMENTOS FORTUITOS NO DIREITO PROCESSUAL PENAL ESTRANGEIRO: ALEMANHA, PORTUGAL, ITÁLIA E ESPANHA}

Muitos autores nacionais recorrem ao direito estrangeiro para fixar critérios para a validade da prova oriunda de investigação por crime diverso. Do mesmo modo, o presente estudo pretende contar com as contribuições da doutrina estrangeira para a solução do problema proposto, o que suscita a necessidade de contextualizar a abordagem do tema na Alemanha, em Portugal, na Itália e na Espanha.

A escolha desses países se deu por diferentes motivos. É que, se por um lado a Alemanha representa o pioneirismo na discussão, tanto no plano doutrinário quanto jurisprudencial, contando desde 1992, com uma disposição normativa sobre o tema, por outro, o regime positivo das interceptações telefônicas sintetizado no Código de Processo Penal português, a partir da Reforma de 2007, revela-se um dos mais avançados textos legislativos sobre a matéria, adotando um regime para a valoração dos conhecimentos fortuitos obtidos através deste meio de obtenção de prova.

No direito processual penal espanhol não existe uma doutrina incontroversamente formada a respeito do assunto, sobretudo, porque, no plano das interceptações telefônicas, está assente em uma regulamentação legal escassa e, nalguns pontos, lacunar, mas a experiência jurisprudencial tem se mostrado digna de análise para fins de paradigma. Já o Código de Processo Penal italiano trata expressamente da questão dentre as normas que regem as interceptações.

A sumária incursão no direito comparado, nos próximos tópicos, fornecerá algumas ideias-chave que se mostrarão úteis na ulterior exposição.

\subsection{Alemanha}

MANUEl Da COSTA ANDRADE destaca que o primeiro pronunciamento de um tribunal alemão sobre os conhecimentos fortuitos remete ao OLG (Oberlandsgericht) de Hamburgo, em decisão de outubro de 1972. O tribunal superior BGH (Bundesgerichtshof), 
por sua vez, teve a primeira oportunidade de se manifestar sobre o tema em março de 1976. ${ }^{139}$ Com efeito, a jurisprudência alemã tomou a dianteira na discussão do tratamento e valoração dos encontros fortuitos obtidos mediante interceptação telefônica.

Mas também no plano doutrinário, a Alemanha constitui a vanguarda no tratamento do tema, e a maioria dos autores, tal como verificado por FRANCISCO AGUILAR relativamente à jurisprudência, partem do pressuposto de que os conhecimentos fortuitos são todos aqueles que não respeitem ao crime do catálogo que, no caso concreto, justificou a decisão judicial da escuta telefônica. ${ }^{140}$

É que a Alemanha, no $\$ 100$ a) da StPO (Código de Processo Penal alemão), além de definir o círculo de pessoas cujas comunicações podem ser interceptadas, prevê expressamente um catálogo de crimes que permitem a autorização de uma interceptação telefônica para sua investigação e possível acusação. A lei alemã também estabelece limiares objetivos e bem definidos para a medida, quer quanto ao grau de suspeita (que há de basear-se em fatos determinados), quer quanto à subsidiariedade (quando a obtenção da prova seria, de outra forma, impossível ou essencialmente dificultada). ${ }^{141}$

Porém, o silêncio legislativo quanto à solução jurídica da questão, que serviu de pano de fundo ao desenvolvimento jurisprudencial e doutrinal, foi rompido com a Lei de Combate ao Tráfico Ilegal de Estupefacientes e outras formas de Criminalidade Organizada, de 15/07/1992, oportunidade em que o legislador alemão se pronunciou, pela primeira vez, sobre a problemática dos conhecimentos fortuitos no âmbito das escutas telefônicas.

FRANCISCO AGUILAR afirma que a inovação legislativa, ao introduzir novo inciso V ao parágrafo $\$ 100$ b) da StPO, passou a admitir a valoração probatória dos conhecimentos fortuitos em outros processos-crime apenas com o propósito do esclarecimento de um delito do catálogo do $§ 100$ a) da StPO. ${ }^{142}$

Tal enquadramento legislativo veio a consagrar a orientação generalizada da doutrina e jurisprudência alemãs no sentido de admitir a valoração dos conhecimentos fortuitos que se reportem a um dos crimes constantes do taxativo rol. Entretanto,

\footnotetext{
${ }^{139}$ Sobre as Proibições... op.cit., p.307. Sobre o conteúdo de cada uma dessas decisões, mais detalhadamente, cf. MAnuel Monteiro Guedes VAlente (Conhecimentos fortuitos... op.cit., p.103-105) e FrancISCO AGUILAR (Dos conhecimentos fortuitos... op.cit., p.28-34).

${ }^{140}$ Dos conhecimentos fortuitos... op.cit., p.27-28 e 41.

${ }^{141}$ ANDRADE, Sobre as Proibições... op.cit., p.288.

${ }^{142}$ Dos conhecimentos fortuitos... op.cit., p.48.
} 
permaneceu a dúvida sobre a valoração dos conhecimentos fortuitos de crimes que, embora não pertencendo ao catálogo legal, estariam em conexão com um destes delitos.

Manuel Monteiro Guedes Valente destaca que o BGH, em decisão de março de 1998, adotou a regra da valoração dos conhecimentos fortuitos relativamente aos delitos do $§ 100$ a) da StPO, afastando a priori a valoração de conhecimentos fortuitos de crimes não catalogados, salvo quando em conexão com o delito do catálogo legitimador da interceptação telefônica. ${ }^{143}$

No mesmo sentido, Francisco Aguilar destaca que, a partir desta decisão, reiterando a norma introduzida pela redação de 1992 do inciso V do $§ 100$ b) da StPO, o tribunal germânico passou a defender que só é possível a valoração dos conhecimentos fortuitos esclarecedores de delitos não catalogares que apresentam uma "estreita referência" no que respeita ao delito do catálogo constante da ordem legitimadora da escuta telefônica. ${ }^{144}$

É também o entendimento de RoxIN, que analisando o dispositivo, afirma:

Para los llamados hallazgos casuales, esto es, para los conocimientos que no conciernen al hecho punible con relación al cual fue ordenada la vigilancia telefónica, el $\$ 100 b, V$, establece una regulación especial en virtud de la cual la valoración entra en consideración sólo para comprobar los hechos de la lista del \$100a o delitos relacionados con ellos. $^{145}$

Até agora só se tratou do desenvolvimento da problemática subjacente ao tema no âmbito da interceptação telefônica. Isto porque, foi através deste meio de obtenção de prova que o tema surgiu na discussão jurisprudencial e doutrinal alemãs.

Mas merece destaque observar que, como informa FRANCISCO AGUILAR, “o $§ 108$ da StPO contempla expressamente o problema dos conhecimentos fortuitos ao prever a apreensão de objetos relativos ao cometimento de 'outro delito' e ao permitir a respectiva tomada de conhecimento por parte das autoridades de perseguição criminal". ${ }^{146}$ Sobre o tema, esclarece Roxin:

\footnotetext{
${ }^{143}$ Conhecimentos fortuitos... op.cit., p.107-108.

${ }^{144}$ Dos conhecimentos fortuitos... op.cit., p.49.

145 Derecho procesal penal. Tradução de Gabriela E. Córdoba e Daniel R. Pastor. Buenos Aires: Editores Del Puerto, 2003. p.202. (sem grifos no original)

${ }^{146}$ Dos conhecimentos fortuitos... op.cit., p. 81 .
} 
$\mathrm{Si}$ en el registro domiciliario son halladas cosas que indican la perpetración de otra acción punible (los llamados 'hallazgos casuales'...), ellas deben ser secuestradas provisionalmente; se le debe dar conocimiento a la fiscalía (...). De todos modos, el §108 implica una extensión de la facultad de ordenar el secuestro a todo funcionario que lleva a cabo el registro. Sin embargo, una extensión semejante presupone que la orden de registro era legítima (...). También es inadmisible una búsqueda dirigida a 'hallazgos casuales'. ${ }^{147}$

\subsection{Portugal}

Prescreve o $\mathrm{n}^{\mathrm{o}} 1$ do artigo 34 da Constituição portuguesa que "O domicílio e o sigilo da correspondência e dos outros meios de comunicação privada são invioláveis", particularizando o $\mathrm{n}^{\mathrm{o}} 4$ do mesmo dispositivo ser "proibida toda a ingerência das autoridades públicas na correspondência e nas telecomunicações, salvos os casos previstos na lei em matéria de processo criminal". ${ }^{148}$

O artigo 187 do Código de Processo Penal português corporifica precisamente a exceção indicada no trecho final do comando constitucional, porquanto impõe alguns pressupostos, que reforçam a ideia de excepcionalidade da medida de interceptação telefônica. Com efeito, exige autorização judicial fundamentada, concedida à luz do principio da subsidiariedade, e estabelece um sistema de catálogo de crimes (artigo $187 \mathrm{n}^{\circ} \mathrm{s}$ 1 e 2) relativamente aos quais é admissível recorrer à interceptação telefônica como meio de obtenção de prova, confiando exclusivamente ao juiz a autorização, e limitando as pessoas que estão sujeitas à medida - catálogo de alvos (artigo 187, $\left.\mathrm{n}^{\circ} 4\right){ }^{149}$

\footnotetext{
${ }_{147}^{147}$ Derecho procesal penal... op.cit., p.318.

PORTUGAL. Constituição da República Portuguesa. Disponível em

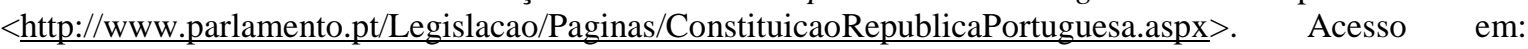
02/07/2011.

149 “Artigo $187 .^{\circ}$

1 - A intercepção e a gravação de conversações ou comunicações telefónicas só podem ser autorizadas durante o inquérito, se houver razões para crer que a diligência é indispensável para a descoberta da verdade ou que a prova seria, de outra forma, impossível ou muito difícil de obter, por despacho fundamentado do juiz de instrução e mediante requerimento do Ministério Público, quanto a crimes:

a) Puníveis com pena de prisão superior, no seu máximo, a 3 anos;

b) Relativos ao tráfico de estupefacientes;

c) De detenção de arma proibida e de tráfico de armas;

d) De contrabando;

e) De injúria, de ameaça, de coacção, de devassa da vida privada e perturbação da paz e do sossego, quando cometidos através de telefone;

f) De ameaça com prática de crime ou de abuso e simulação de sinais de perigo; ou

g) De evasão, quando o arguido haja sido condenado por algum dos crimes previstos nas alíneas anteriores.
} 
Observa-se que a interceptação telefônica no direito processual penal português (lá ditas genericamente escutas telefónicas) é reservada exclusivamente a tipos criminais que, pelas suas características, tornam tal meio de obtenção de prova particularmente apto à investigação ou que, pela gravidade dos interesses em jogo, podem justificar a adoção da medida.

Todavia, conforme já advertia MANUEL DA CostA ANDRADE em 1992, “As escutas telefônicas são, na verdade, portadoras de uma danosidade social polimórfica e pluridimensional que, em geral, não é possível conter nos limites, em concreto e à partida, tidos como acertados". 150

Não obstante, até a reforma de 2007, o legislador não dava nenhuma indicação de como proceder face aos conhecimentos fortuitos advindos da medida, levando a doutrina a se posicionar. Chama atenção a amplitude da discussão, bem destacada por MANUEL MonteIRo GuEDES VALENTE, que assim demonstrou as reações antagônicas que o tema provocava em Portugal:

(...) por um lado, os defensores dos direitos, liberdades e garantias dos cidadãos - que empunham a espada contra a absolutização da verdade a qualquer custo - criticam não só a indiscriminação e o desnorte da selecção do que é escutado e do que é ou deve ser transcrito, mas também

2 - A autorização a que alude o número anterior pode ser solicitada ao juiz dos lugares onde eventualmente se puder efectivar a conversação ou comunicação telefónica ou da sede da entidade competente para a investigação criminal, tratando-se dos seguintes crimes:

a) Terrorismo, criminalidade violenta ou altamente organizada;

b) Sequestro, rapto e tomada de reféns;

c) Contra a identidade cultural e integridade pessoal, previstos no título III do livro II do Código Penal e previstos na Lei Penal Relativa às Violações do Direito Internacional Humanitário;

d) Contra a segurança do Estado previstos no capítulo I do título V do livro II do Código

Penal;

e) Falsificação de moeda ou títulos equiparados a moeda prevista nos artigos $262 .^{\circ}, 264 .^{\circ}$, na parte em que remete para o artigo $262 .^{\circ}$, e $267 .^{\circ}$, na parte em que remete para os artigos $262 .^{\circ}$ e $264 .^{\circ}$, do Código Penal;

e) Falsificação de moeda ou títulos equiparados a moeda prevista nos artigos $262 .^{\circ}, 264 .^{\circ}$, na parte em que remete para o artigo $262 .^{\circ}$, e $267 .^{\circ}$, na parte em que remete para os artigos $262 .^{\circ}$ e $264 .^{\circ}$, do Código Penal;

f) Abrangidos por convenção sobre segurança da navegação aérea ou marítima.

3 - Nos casos previstos no número anterior, a autorização é levada, no prazo máximo de setenta e duas horas, ao conhecimento do juiz do processo, a quem cabe praticar os actos jurisdicionais subsequentes.

4 - A intercepção e a gravação previstas nos números anteriores só podem ser autorizadas, independentemente da titularidade do meio de comunicação utilizado, contra:

a) Suspeito ou arguido;

b) Pessoa que sirva de intermediário, relativamente à qual haja fundadas razões para crer que recebe ou transmite mensagens destinadas ou provenientes de suspeito ou arguido; ou

c) Vítima de crime, mediante o respectivo consentimento, efectivo ou presumido."

(PORTUGAL. Codigo de Processo Penal. $\quad$ Disponível <http://www.pgdlisboa.pt/pgdl/leis/lei_print_articulado.php?tabela=leis\&artigo id=\&nid=199\&nversao=\&ta bela=leis >. Acesso em: 02/07/2011).

${ }^{150}$ Sobre as Proibições... op.cit., p. 283. 
os arautos da valoração total dos conhecimentos ou factos obtidos fortuitamente; mas, por outro lado, os guerreiros da segurança a qualquer custo e da restrição de direitos e liberdades em prol da "justiça" que erguem a voz contra as restrições adstritas aos operadores judiciários não só quanto à selecção do que é escutado e do que é transcrito, argüindo a total transcrição para os autos do que fora escutado, para que a verdade ou a aparente verdade seja do conhecimento do "povo", mas também quanto à valoração total dos conhecimentos que não se reportam ao crime que fundamentou a realização das escutas, i.e., a valoração sem restrições dos conhecimentos fortuitos. ${ }^{151}$

Este contexto sugere que se destaquem duas grandes referências na doutrina portuguesa, pela contribuição que tiveram na discussão do tratamento processual da figura dos conhecimentos fortuitos.

MANUEl DA COSTA ANDRADE, primeiro autor a se manifestar sobre a problemática, na obra Sobre as Proibições de Prova em Processo Penal (1992), defendia a tese da valoração dos conhecimentos fortuitos adstrita aos crimes do catálogo (exigência mínima de que se reportem a uma das infrações do art.187 do CPP), acrescentando que, para além disso, acreditava

(...) ser mais consistente a posição dos autores que, a par do crime do catálogo, fazem intervir exigências complementares tendentes a reproduzir aquele estado de necessidade investigatório que o legislador terá arquetipicamente representado como fundamento da legitimação (excepcional) das escutas telefónicas. Qualquer outro entendimento que reduzisse as exigências e, nessa medida, abatesse algumas das defesas do cidadão só seria possível em nome de uma hermenêutica menos atenta ao peso dos elementos sistemático, teleológico e político-criminal. ${ }^{152}$

Por seu lado, Germano Marques da Silva, no seu Curso de Processo Penal (1999), admitia apenas a valoração dos conhecimentos fortuitos que, simplesmente, se reportassem "a um dos crimes relativamente aos quais a escuta é legalmente admissível". 153

Francisco Aguilar ${ }^{154}$ e Manuel Monteiro Guedes VAlente ${ }^{155}$, em obras mais recentes e específicas sobre o tema, também enfrentaram a problemática no sistema

${ }^{151}$ Conhecimentos fortuitos... op.cit.,p.40.

152 op.cit., p.311-312.

153 op.cit., p. 205.

${ }^{154}$ Dos conhecimentos fortuitos... op.cit.

${ }^{155}$ Conhecimentos fortuitos... op.cit. 
processual penal português, e serão de extrema importância na busca de um critério suscetível de determinar o âmbito de admissibilidade dos conhecimentos fortuitos no sistema processual penal brasileiro. Mas, por ora, cumpre enfatizar a valiosa contribuição destes estudos na doutrina portuguesa, embora ambos - e até por isso mesmo - também tenham sido escritos antes do enquadramento legislativo da questão no ordenamento lusitano.

É que foi apenas com as alterações introduzidas pela Lei $n^{\circ} 48 / 2007$ que o legislador ordinário, no novo $\mathrm{n}^{\mathrm{o}} 7$ do art. 187 do CPP português, estabeleceu um regime para a valoração dos conhecimentos fortuitos obtidos através das escutas telefônicas, prevendo que "a gravação de conversações ou comunicações só pode ser utilizada em outro processo, em curso ou a instaurar, se tiver resultado de intercepção de meio de comunicação utilizado por pessoa referida no n. $^{\circ} 4$ e na medida em que for indispensável à prova de crime previsto no n. $^{\mathrm{o}} 1$ ". 156

Assim, como consequência da taxatividade dos crimes que admitem este meio intrusivo de obtenção de prova e dos seus possíveis alvos, nas palavras de GERMANO MARQues DA Silva, em suas Notas sobre as Alterações de 2007 ao Código de Processo Penal Português, o novo dispositivo "veio pôr na lei o que antes era apenas orientação de parte da doutrina". ${ }^{157}$ Segundo INÊS MOREIRA SANTOS:

Com esta reforma legislativa, que permitiu ao legislador pronunciar-se sobre esta matéria, veio acalmar muitas vozes críticas, quer no seio da Doutrina quer na Jurisprudência que, ao longo dos tempos foram tentando colmatar esta lacuna legal e que acabaram por dar desta forma, um enorme contributo para que se positivasse esta solução. ${ }^{158}$

Em suma, no sistema processual penal português, "o conhecimento fortuito vale como prova quando resultar de interceptação de meio de comunicação usado por pessoa indicada no $\mathrm{n}^{\circ} 4$ (catálogo de alvos) do art.187 e quando se refira a um dos crimes do catálogo relativamente aos quais a escuta telefônica é legalmente admissível (catálogo de crimes)". ${ }^{159}$

\footnotetext{
${ }^{156}$ PORTUGAL. Codigo de Processo Penal... cit.

${ }^{157}$ In: Carvalho, Luis Gustavo Grandinetti Castanho de (Org). Processo Penal do Brasil e de Portugal: estudo comparado: as reformas portuguesa e brasileira. Coimbra: Almedina, 2009. p.79.

${ }^{158}$ Direito fundamental à privacidade... op.cit., p.118.

${ }^{159}$ LIMA, Monica Isabel Fonseca Sequeira. Conhecimentos fortuitos nas escutas telefónicas: razão de ser dos crimes de catálogo. Lisboa, 06 de fevereiro de 2011. p.4. Disponível em <
} 
No que se refere à busca e apreensão, o Código de Processo Penal português, sob a designação de meios de obtenção de prova, regula no seu Título III, capítulos que versam sucessivamente sobre as revistas e buscas (Capítulo II) e as apreensões (Capítulo III).

Mas, diferente do que ocorre com a interceptação telefônica - que não suporta qualquer possibilidade de ser realizada sem ordem de autoridade judicial - no processo penal português, as buscas e apreensões podem funcionar como típica medida cautelar e de polícia.

Com efeito, a busca domiciliária, prevista no artigo 177 do CPP português ${ }^{160}$, embora, via de regra, só possa ser ordenada ou autorizada pelo juiz (art.177, $\mathrm{n}^{\mathbf{o}} 1$ ), excepcionalmente também pode ser ordenada pelo Ministério Público ou ser efetuada por órgão de polícia criminal (art.177, $\mathrm{n}^{\mathrm{o}} 3$ ). Nos casos em que for efetuada por órgão de polícia criminal sem consentimento do visado e fora de flagrante delito, a realização da diligência deve ser, sob pena de nulidade, imediatamente comunicada ao juiz de instrução e por este apreciada em ordem à sua validação (art.177, no 4).

Assim, no direito processual penal português, como se deixa patente na linha de Manuel Monteiro Guedes Valente:

A discussão em torno dos conhecimentos fortuitos relevam,
sobremaneira, no plano das escutas telefónicas, por ser unânime a sua
quase irrelevância no plano (...) das buscas e das apreensões, meios de
obtenção de prova tradicionais, que, por um lado, devem, por regra, ser
operacionalizados por autorização ou ordem judicial e, por outro, ou por
razões de legítima defesa, de direito de necessidade, estado de
necessidade ou conflito de direitos e deveres ou por preencherem a
tipicidade das medidas cautelares de polícia podem ser operacionalizadas

<http://pt.scribd.com/doc/49381612/Conhecimentos-Fortuitos-nas-Escutas-Telefonicas-Razao-de-ser-doscrimes-de-catalogo>. Acesso em: 14/06/2011.

160 "Artigo $177 .^{\circ}$ Busca domiciliária

1 - A busca em casa habitada ou numa sua dependência fechada só pode ser ordenada ou autorizada pelo juiz e efectuada entre as $7 \mathrm{e}$ as 21 horas, sob pena de nulidade.

2 - Entre as 21 e as 7 horas, a busca domiciliária só pode ser realizada nos casos de:

a) Terrorismo ou criminalidade especialmente violenta ou altamente organizada;

b) Consentimento do visado, documentado por qualquer forma;

c) Flagrante delito pela prática de crime punível com pena de prisão superior, no seu máximo, a 3 anos.

3 - As buscas domiciliárias podem também ser ordenadas pelo Ministério Público ou ser efectuadas por órgão de polícia criminal:

a) Nos casos referidos no n. ${ }^{\circ} 5$ do artigo $174 .^{\circ}$, entre as 7 e as 21 horas;

b) Nos casos referidos nas alíneas b) e c) do número anterior, entre as 21 e as 7 horas.

4 - É correspondentemente aplicável o disposto no n. ${ }^{\circ} 6$ do artigo $174 .^{\circ}$ nos casos em que a busca domiciliária for efectuada por órgão de polícia criminal sem consentimento do visado e fora de flagrante delito (...)."

"Art. $174^{\circ}$ (...) 6 - (...) a realização da diligência é, sob pena de nulidade, imediatamente comunicada ao juiz de instrução e por este apreciada em ordem à sua validação." (PORTUGAL. Codigo de Processo Penal... cit.). 
sem a prévia autorização ou ordem judicial sob condição de posterior e imediata comunicação, apreciação e validação judicial. ${ }^{161}$

Posto isto, o autor adere à tese da admissibilidade geral da apreensão e valoração de todos os conhecimentos fortuitos obtidos por meio de uma busca, até porque, o artigo 178 do CPP português autoriza que se apreendam todos os objetos relacionados com um crime, sendo este meio de obtenção de prova admitido como válido para a investigação de qualquer crime (não está sujeito a um catálogo). ${ }^{162}$

Neste contexto é que MANUEl DA Costa ANDRADE, analisando o tema dos encontros fortuitos, já então afirmava que nada parece contrariar a tese da admissibilidade geral da apreensão e valoração de todos os conhecimentos fortuitos no domínio específico das buscas. ${ }^{163}$

\subsection{Itália}

Dentre os meios de obtenção de prova previstos no Código de Processo Penal italiano de 1988 (Codice di Procedura Penale, Libro III, Titolo III - Mezzi di ricerca della prova), merece destaque aquele previsto no Capítulo IV (Intercettazioni di conversazioni o comunicazioni), já que é no seu âmbito que o tema dos conhecimentos fortuitos é tratado expressamente.

Em seu artigo $266^{164}$, o código italiano limita a admissibilidade das interceptações de comunicações telefônicas, elencando um rol de crimes para os quais o meio de obtenção

\footnotetext{
${ }^{161}$ Conhecimentos fortuitos... op.cit., p.97.

162 Ibid., p.101. Pertinente a transcrição do mencionado artigo 178 do CPP português: "1 - São apreendidos os objectos que tiverem servido ou estivessem destinados a servir a prática de um crime, os que constituírem o seu produto, lucro, preço ou recompensa, e bem assim todos os objectos que tiverem sido deixados pelo agente no local do crime ou quaisquer outros susceptíveis de servir a prova." (PORTUGAL. Codigo de Processo Penal... cit.).

${ }^{163}$ Sobre as Proibições... op.cit.,p. 277.

164 “Art. 266. Limiti di ammissibilità.

1. L'intercettazione di conversazioni o comunicazioni telefoniche e di altre forme di telecomunicazione è consentita nei procedimenti relativi ai seguenti reati:

a) delitti non colposi per i quali è prevista la pena dell'ergastolo o della reclusione superiore nel massimo a cinque anni determinata a norma dell'articolo 4;

b) delitti contro la pubblica amministrazione per i quali è prevista la pena della reclusione non inferiore nel massimo a cinque anni determinata a norma dell'articolo 4;

c) delitti concernenti sostanze stupefacenti o psicotrope;
} 
de prova é consentido, tais como: crimes dolosos para os quais seja prevista a pena de reclusão superior ao máximo de cinco anos, crimes relacionados a substâncias entorpecentes ou psicotrópicas, crimes relacionados a armas ou substâncias explosivas, crimes de contrabando, injúria e ameaça, e crimes relacionados a distúrbios às pessoas por meio do telefone.

Como regra, conforme previsão do artigo $267^{165}$, o requerimento para a interceptação das conversas telefônicas deve ser formulado pelo Ministério Público e a autorização deve ser concedida por meio de decisão judicial fundamentada, quando estiverem presentes graves indícios de crime e a interceptação for absolutamente indispensável ao prosseguimento das investigações.

Excepcionalmente, a teor do que dispõe o próprio artigo 267, $\mathrm{n}^{\mathrm{o}} 2$, e diferentemente do que ocorre no direito brasileiro, em casos de urgência, quando existir motivo fundado para se acreditar que a demora possa causar prejuízo sério às investigações, o Ministério Público pode proceder à interceptação por meio de decisão motivada, desde que comunique imediatamente ou no mais tardar em 24 (vinte e quatro) horas, ao juiz competente, que dentro de um prazo de 48 (quarenta e oito), decidirá motivadamente sobre a convalidação da medida. Se a decisão do Ministério Público não

d) delitti concernenti le armi e le sostanze esplosive;

e) delitti di contrabbando;

f) reati di ingiuria, minaccia, usura, abusiva attività finanziaria, abuso di informazioni privilegiate, manipolazione del mercato, molestia o disturbo alle persone col mezzo del telefono;

f-bis) delitti previsti dall'articolo 600-ter, terzo comma, del codice penale, anche se relativi al materiale pornografico di cui all'articolo 600-quater.1 del medesimo codice." (GATTI, Giustino. Codice di procedura penale: annotato con la giurisprudenza. XVIII edizione. Napoli: Edizioni Giuridiche Simone, 2010. p.653).

165 "Art. 267. Presupposti e forme del provvedimento.

1. Il pubblico ministero richiede al giudice per le indagini preliminari l'autorizzazione a disporre le operazioni previste dall'art. 266. L'autorizzazione è data con decreto motivato quando vi sono gravi indizi di reato e l'intercettazione è assolutamente indispensabile ai fini della prosecuzione delle indagini.

1-bis. Nella valutazione dei gravi indizi di reato si applica l'articolo 203.

2. Nei casi di urgenza, quando vi è fondato motivo di ritenere che dal ritardo possa derivare grave pregiudizio alle indagini, il pubblico ministero dispone l'intercettazione con decreto motivato, che va comunicato immediatamente e comunque non oltre le ventiquattro ore al giudice indicato nel comma 1. Il giudice, entro quarantotto ore dal provvedimento, decide sulla convalida con decreto motivato. Se il decreto del pubblico ministero non viene convalidato nel termine stabilito, l'intercettazione non può essere proseguita e i risultati di essa non possono essere utilizzati.

3. Il decreto del pubblico ministero che dispone l'intercettazione indica le modalità e la durata delle operazioni. Tale durata non può superare i quindici giorni, ma può essere prorogata dal giudice con decreto motivato per periodi successivi di quindici giorni, qualora permangano i presupposti indicati nel comma 1.

4. Il pubblico ministero procede alle operazioni personalmente ovvero avvalendosi di un ufficiale di polizia giudiziaria.

5. In apposito registro riservato tenuto nell'ufficio del pubblico ministero sono annotati, secondo un ordine cronologico, i decreti che dispongono, autorizzano, convalidano o prorogano le intercettazioni e, per ciascuna intercettazione, l'inizio e il termine delle operazioni." (Ibid., p.667). 
for convalidada pelo juiz dentro do prazo estabelecido, a interceptação não poderá prosseguir e as informações resultantes dela não poderão ser utilizadas.

Já o artigo $270^{166}$ da legislação processual penal italiana veda a utilização dos resultados das interceptações em procedimentos diversos daqueles em que foram autorizadas, ressalvado o caso de sua indispensabilidade para o acertamento de infrações penais em que for obrigatória a prisão em flagrante.

GiUSTINO GATTI, citando precedentes de tribunais italianos, enfatiza que o artigo 270 permite a utilização dos resultados das interceptações em outros procedimentos apenas quando relativos a crimes nos quais é obrigatória a prisão em flagrante. ${ }^{167}$

Entretanto, analisando o conteúdo dessa norma com base em precedentes jurisprudenciais que avaliam a extensão da proibição de utilização dos resultados das interceptações em procedimentos diversos daqueles em que foram autorizadas, GIORGIO LATTANZI explica que os limites impostos pelo dispositivo se referem somente à utilização do material como elemento de prova, mas não excluem a possibilidade de deduzir notícia de crime no âmbito de outro procedimento. A proibição de utilização dos resultados das interceptações prevista no artigo 270 deve, portanto, ser entendida no sentido de que tais elementos não podem valer como prova em processo distinto, embora nada impeça sua utilização como notícia de ilícito penal válida para diferente investigação destinada à obtenção de novos elementos de prova. ${ }^{168}$

As decisões colacionadas por GIUSTINO GATTI não são diferentes, e registram que o preceito legal interessa à valoração dos resultados obtidos mediante interceptação

\footnotetext{
166 “Art. 270. Utilizzazione in altri procedimenti.

1. I risultati delle intercettazioni non possono essere utilizzati in procedimenti diversi da quelli nei quali sono stati disposti, salvo che risultino indispensabili per l'accertamento di delitti per i quali è obbligatorio l'arresto in flagranza." (Ibid., p.697).

167 “(...) consente l'utilizzazione dei risultati delle intercettazioni in altri procedimenti solo limitatamente ai procedimenti relativi ai reati per i quali è obbligatorio l'arresto in flagranza”. (Ibid., p.698).

168 "I limiti imposti da detta norma, infatti, si riferiscono soltanto a processi diversi e all'utilizzabilità di quei risultati come elementi di prova, mentre non escludono la possibilita di dedurre notizie di reato dalle intercettazioni legittimamente disposte nell'ambito di altro procedimento. (...) Il divieto di utilizzazione dei risultati delle intercettazioni in altro procedimento, di cui all'art.270, va, quindi, inteso nel senso che non possono siffatti elementi valere come prova in diverso processo. Nessuna preclusione esiste, invece, circa la utilizzazione di tali intercettazioni quale notizia di illecito penale valida pel l'inizio di um diverso procedimento e per l'espletamento di accertamenti volti ad acquisire nuovi elementi di prova." (Codice di procedura penale: rassegna di giurisprudenza e di dottrina. Libri II e III. Milano: Giuffrè Editore, 1997. p.825-826).
} 
telefônica como elementos de prova, e não ao seu valor como fonte de uma notícia de crime ou simplesmente como ponto de partida para novas e diversas investigações. ${ }^{169}$

Assim, referido comando legal resolve, indiretamente, o problema da admissão dos conhecimentos fortuitos no âmbito das interceptações telefônicas no processo penal italiano, estabelecendo, portanto, como regra, segundo sintetiza PAOLO TONINI, que:

(...) os resultados das interceptações são utilizáveis somente no âmbito do procedimento em que são determinadas. Permanecem, no entanto, utilizáveis como notitia criminis para outros procedimentos. Todavia, podem ser utilizados em outros procedimentos quando forem indispensáveis para a averiguação dos delitos para os quais é obrigatória a prisão em flagrante (art.270 do CPP). ${ }^{170}$

\subsection{Espanha}

O artigo 579 da Ley de Enjuiciamiento Criminal, com a redação dada pela Ley Orgánica 4/1988, trata da possibilidade da interceptação das comunicações telefônicas nos seguintes termos:

Artículo 579.
1. Podrá el Juez acordar la detención de la correspondencia privada,
postal y telegráfica que el procesado remitiere o recibiere y su apertura y
examen, si hubiere indicios de obtener por estos medios el
descubrimiento o la comprobación de algún hecho o circunstancia
importante de la causa.
2. Asimismo, el Juez podrá acordar, en resolución motivada, la
intervención de las comunicaciones telefónicas del procesado, si hubiere
indicios de obtener por estos medios el descubrimiento o la
comprobación de algún hecho o circunstancia importante de la causa.
3. De igual forma, el Juez podrá acordar, en resolución motivada,
por un plazo de hasta tres meses, prorrogable por iguales períodos, la
observación le las comunicaciones postales, telegráficas o telefónicas
de las personas obre las que existan indicios de responsabilidad

169 “Le prescrizioni dell'art. 270 cod. proc. pen. a proposito dell'utilizzazione in procedimenti diversi delle risultanze acquisite mediante intercettazioni telefoniche riguardano l'apprezzamento di dette risultanze quali elementi di prova, e non attengono invece alla loro valorizzazione come fonti della notizia di reato o semplici spunti per nuove e diverse investigazioni”. (Codice di procedura penale... op.cit., p.701).

${ }^{170}$ A prova... op.cit., p.252. 


\section{criminal, así como de las comunicaciones de las que se sirvan para la realización de sus fines delictivos. (...) ${ }^{171}$}

Observa-se que o ordenamento jurídico espanhol, a exemplo do brasileiro, não prevê um catálogo de crimes que permitem a autorização de uma interceptação telefônica para sua investigação. Aliás, sequer conta com um critério objetivo de limitação desse meio de obtenção de prova, assente numa regulamentação legal tão escassa que, na verdade, as indicações legais resumem-se praticamente à indicação da obrigatoriedade da medida de intervenção ser ordenada judicialmente. ${ }^{172}$

Por isso, consoante CARlos Alberto CARbOne, as primeiras opiniões sobre o tema do encontro fortuito na doutrina espanhola se deram no âmbito desse meio de obtenção de prova e sob a perspectiva da gravidade do crime, no sentido de invalidar os conhecimentos que não se referiam a delitos graves. E também sob a perspectiva do sujeito passivo da medida: “Cuando se 'encuentran' delitos graves, si se refieren a la misma persona contra la que se dispuso la intervención, es utilizable en otro juicio en base a todas

171 ESPANHA. Ley de Enjuiciamiento Criminal. Disponível em: <http://noticias.juridicas.com/base_datos/Penal/lecr.html>. Acesso em: 15/04/2012.

${ }^{172}$ Merece referência a condenação imposta pelo Tribunal Europeu dos Direitos do Homem (TEDH) ao governo espanhol no Caso PRADO BUGALLO c. ESPANHA, em razão da obscuridade de sua legislação de interceptação telefônica. Vale transcrever o consignado na decisão do TEDH, atinente ao caso: "RESPEITO DA VIDA PRIVADA (ART. $8^{\circ}$ ) - RESPEITO DA CORRESPONDÊNCIA (ART. $8^{\circ}$ ) INGERÊNCIA - PREVISTA NA LEI. I. A intercepção e escuta de conversas telefónicas encontra-se regulada no código de processo penal espanhol, que foi alterado nesta matéria por uma lei de 1988 que, apesar das garantias introduzidas, não satisfaz as condições exigidas na jurisprudência do Tribunal para evitar arbitrariedades. II. As insuficiências legais caracterizam-se pela falta de definição da natureza das infracções penais que poderão dar origem à autorização de escutas, pela ausência de um limite temporal de duração destas medidas, pelo procedimento de transcrição das conversas/comunicações escutadas - que é da exclusiva competência do secretário judicial - e ainda, por não ser possível garantir que as gravações são guardadas na íntegra, a fim de poderem ser, eventualmente, controladas por um juiz ou pela defesa. III. Estas lacunas foram objecto de apreciação pelas jurisdições nacionais superiores que consideraram as alterações legislativas insuficientes face às exigências que devem rodear as medidas de autorização de escutas telefónicas, havendo a necessidade de definir garantias suplementares relativas ao âmbito e modalidades do poder de apreciação dos juízes. IV. À data em que as escutas foram efectuadas persistiam importantes lacunas legislativas que a jurisprudência, nomeadamente do Supremo Tribunal Nacional, pretendeu colmatar; todavia, e apesar da evolução jurisprudencial verificada, supondo que a mesma pudesse superar as lacunas da lei em sentido formal, esta é posterior à decisão do juiz de instrução criminal que ordenou a colocação sob escuta dos telefones das pessoas que participavam das actividades ilícitas dirigidas pelo requerente, por isso, não existindo previsão legal bastante, verifica-se a violação do artigo $8^{\circ}$ da Convenção.". (TRIBUNAL EUROPEU DOS DIREITOS DO HOMEM (TEDH). Caso PRADO BUGALLO c. ESPANHA, acórdão de 18 de Fevereiro de 2003. In: PORTUGAL. Procuradoria-Geral da República. Agente do Governo Português junto do Tribunal Europeu dos Direitos do Homem. Gabinete de Documentação e Direito Comparado. Sumários de Jurisprudência 2003, p.41. Disponível em <http://www.gddc.pt/direitos-humanos/sist-europeudh/Sum\%E1rios\%202003.pdf >. Acesso em: 15/04/2012). 
las garantías que se tuvieron en cuenta al ordenarla. Contrariamente, si ese delito nuevo se refiere a terceras personas se excluiría toda consideración". ${ }^{173}$

Ao mencionar que esta teoria se encontra superada na Espanha, o autor cita que alguns estudiosos da questão preferem enfrentar o problema dos conhecimentos fortuitos afastando sua utilização "cuando revelen hechos totalmente independientes del investigado en el proceso o cuando se refiera a un tercero no sujeto pasivo, en sintonía con lo que vimos de la doctrina alemana". E outros defendem a necessidade de “(...) obtener una ampliación de la resolución judicial (...)" para se outorgar validade aos conhecimentos fortuitos. $^{174}$

Alfonso Serrano Maíllo defende essa necessidade de ampliação da autorização judicial: "Son nulas las pruebas que se consiguen cuando durante las conversaciones se desprende la comisión de un delito distinto. En estos casos habrá que pedir al juez autorización para investigar el nuevo delito." ${ }^{175}$ Esta também é a opinião de ECHARRI CASI:

(...) lo más adecuado, sería suspender el acto, y solicitar la correspondiente ampliación de la autorización judicial, si no lo hacen así, y no se cumplen las exigencias constitucionales, más que en presencia de un hallazgo casual, estaremos ante una prueba ilícitamente obtenida. (...) La relevancia constitucional del hallazgo casual estará constitucionalmente justificada, cuando hubo posibilidad de obtener, sin merma de la investigación, la ampliación de la resolución judicial, de lo contrario, carecerá de eficacia. En los casos en que no sea posible solicitar esa ampliación, el hallazgo casual desplegará toda su virtualidad. ${ }^{176}$

Na jurisprudência espanhola também parece predominar esse entendimento, no sentido de que para se continuar uma investigação sobre novos fatos, com base em evidências probatórias que inesperadamente aparecem no curso de uma interceptação telefônica, de forma totalmente imprevista, a medida deve ser ampliada, com fundamento no princípio da especialidade, por meio de uma nova decisão judicial que legitime tal

\footnotetext{
${ }^{173}$ Requisitos constitucionales... op.cit., p.378.

174 Ibid., p.378-379.

175 Valor de las escuchas telefónicas como prueba en el sistema español. Nulidad de la prueba obtenida ilegalmente. In: Revista Brasileira de Ciências Criminais, São Paulo, nº 15, p.13-21, jul-set/1996. p.19-20.

${ }^{176}$ Prueba ilícita... op.cit., p.291-292.
} 
surgimento e reconduza a investigação com os fundamentos necessários para sua legítima continuação:

\begin{abstract}
En el momento de adoptar su decisión, el Juez ha de atender, necesariamente a varios aspectos. En primer lugar, a la proporcionalidad, en el sentido de que ha de tratarse de la investigación de un delito grave. Para valorar la gravedad no solo es preciso atender a la previsión legal de una pena privativa de libertad grave, sino además debe valorarse la trascendencia social del delito que se trata de investigar. En segundo lugar, a la especialidad, en tanto que la intervención debe estar relacionada con la investigación de un delito concreto, sin que sean lícitas las observaciones encaminadas a una prospección sobre la conducta de una persona en general. En este sentido, los hallazgos casuales son válidos, pero la continuidad en la investigación de un hecho delictivo nuevo requiere de una renovada autorización judicial. ${ }^{177}$
\end{abstract}

De fato, segundo Manuel Monteiro Guedes Valente, os tribunais espanhóis, com o intuito de salvaguarda eficaz dos direitos fundamentais e de validação dos encontros fortuitos, seja durante uma busca ou uma interceptação telefônica, defendem a sujeição daqueles à comunicação imediata ao juiz, do que pode resultar, caso assim entenda o juiz, ou a uma nova ordem judicial ou ao início de uma nova investigação criminal:

Em Espanha, os Tribunais Superiores, quer o Tribunal Constitucional quer o Tribunal Supremo, têm-se pronunciado sobre os conhecimentos fortuitos - descubrimientos ocasionales - sendo de reter, desde logo, que os operadores judiciários que no âmbito de uma escuta telefónica sobre o crime $\mathbf{X}$ descobrem ou tomam ocasionalmente conhecimento de provas do crime $\mathbf{W}$ devem imediatamente comunicar ao juiz que autorizou a escuta para que a possível violação de direitos fundamentais cesse e emita um novo despacho, por se considerar que, nesse momento, existe uma ingerência ilegítima. ${ }^{178}$

Percebe-se que há uma preocupação com o controle jurisdicional da investigação, sobretudo, porque a não comunicação ao juiz dos conhecimentos fortuitos significa uma ingerência ilegítima, e consequentemente uma violação dos direitos fundamentais do cidadão. Assim, uma vez imediatamente informado o juiz, deve este decidir o pertinente

177 ESPANHA. Tribunal Supremo. Sala de lo Penal. STS 6147/2012. Disponível em: $<$ http://www.poderjudicial.es/search/doAction?action=contentpdf\&databasematch=TS\&reference $=6514953$ $\underline{\text { \&links }=\text { hallazgos } \% 20 \mathrm{y} \% 20 \text { casuales } \% 20 \mathrm{e} \% 20 \text { telefonica \&optimize }=20121016 \& \text { publicinterface }=\text { true }>}$. Acesso em: 02/09/2012. (sem grifos no original)

${ }^{178}$ Conhecimentos fortuitos... op.cit., p. 109. 
acerca da novação do objeto da autorização para que se cumpra a exigência da proporcionalidade da medida restritiva.

Durante um tempo, esta linha jurisprudencial foi trasladada ao âmbito das buscas domiciliárias. Destarte, o princípio da especialidade justificava que se optasse pela suspensão da diligência no momento da descoberta fortuita, a fim de comunicá-la ao juiz autorizador da medida, reclamando deste uma decisão distinta que amparasse a investigação do novo delito, ampliando desse modo o objeto do mandado.

Não obstante, apontando as diferenças entre a interceptação das comunicações telefônicas e as buscas domiciliárias, o Tribunal Supremo (STS 7314/2010) ${ }^{179}$ abandonou aquela orientação, “(...) tanto por la distinta afectación de una y otra diligencia sobre la intimidad, verdaderamente más intensa y directa en la intervención telefónica, como por la prolongación temporal de una y otra injerencia". De acordo com o Tribunal, como a interceptação telefônica, por sua própria natureza, pressupõe uma prolongação temporal, ela permite, "en los casos de escuchas referidas a otras conductas delictivas distintas, una ampliación de la autorización judicial habilitante”. Mas

\footnotetext{
“(...) No sucede lo mismo con las entradas y registros, que se caracterizan por su realización en unidad de acto, de ahí que si en su práctica apareciera objetos constitutivos de un cuerpo de posible delito distinto a aquel para cuya investigación se extendió el mandamiento habilitante, tal descubrimiento se instala en la nota de flagrancia. La Constitución no exige en modo alguno, que el funcionario que se encuentre investigando unos hechos de apariencia delictiva cierre los ojos ante los indicios de delito que se presentasen a su vista, aunque los hallados casualmente sean distintos a los hechos comprendidos en su investigación oficial (...)".
}

Assim, no âmbito dos registros domiciliários, segundo o precedente, passou-se a resolver a questão admitindo "la validez de la diligencia cuando, aunque el registro se dirigiera a la investigación de un delito se encontraran efectos o instrumentos de otro que pudiera entenderse como delito flagrante".

179 ESPANHA. Tribunal Supremo. Sala de lo Penal. STS 7314/2010. Disponível em: $<$ http://www.poderjudicial.es/search/doAction?action=contentpdf \&databasematch=TS\&reference=5836266 \&links=\&optimize=20110203\&publicinterface=true $>$. Acesso em: 02/09/2012. 


\section{O TRATAMENTO DOS CONHECIMENTOS FORTUITOS NO DIREITO PROCESSUAL PENAL BRASILEIRO}

\subsection{O silêncio legislativo}

O ordenamento jurídico brasileiro não dispõe de qualquer referência legislativa relativa à problemática de que se ocupa o presente estudo. De fato, a questão carece de uma regulamentação legal acerca do tratamento dos conhecimentos fortuitos.

Aliás, a Lei 11.690/2008, que alterou dispositivos do Código de Processo Penal relativos à prova, perdeu boa oportunidade de regulamentar a matéria, permanecendo no vácuo a solução jurídica da questão.

Especificamente com relação às interceptações telefônicas - já que é no âmbito deste meio de obtenção de prova que se encontram no direito comparado referências legislativas sobre o tema - também silencia a Lei ${ }^{\circ}$ 9.296/96.

Como exemplo de que a Lei em vigor não configura o projeto de que se originou a melhor proposta entre as oferecidas ao Congresso Nacional, destaca-se o Projeto de Lei $\mathrm{n}^{\mathrm{o}}$ 3.514/1989, conhecido como Projeto Miro Teixeira. O texto proposto trazia, em seu art. $8^{\circ}$, a vedação do aproveitamento dos resultados das operações técnicas de interceptação lícita, para fins de instrução de processos ou investigações relativos a crimes diversos daqueles para os quais a autorização foi dada, salvo quando se tratasse de conhecimento fortuito de crime também constante do rol taxativo do art. $1^{\circ}$, o qual enumerava as hipóteses em que a quebra do sigilo seria admissível. ${ }^{180}$

Aliás, o Anteprojeto de Lei que surgiu em 2003 dos trabalhos de comissão ${ }^{181}$ presidida pela Prof. a ADA PELlegrini GrinOver, constituída pelo então Ministro da Justiça Dr. MÁrcio Thomaz BAstos para realizar nova proposta de lei para as interceptações telefônicas, também restringia este meio de obtenção de prova à apuração

\footnotetext{
${ }^{180} \mathrm{O}$ texto do Projeto encontra-se publicado na obra de autoria de ADA PELleGrini Grinover, Novas tendências... op.cit., p.430-435).

${ }^{181}$ Integravam a Comissão: AdA PELlEgrini Grinover, ANTÔNIO CARlos DE AlMEIDA CASTRO, ANTONIO MagalHÃes Gomes Filho, ANTONio SCARANCE FERNANDES e LuIZ GuILHERME VIEIRA.
} 
de determinados crimes que elencava taxativamente no art. $1^{\circ}$ do texto ${ }^{182}$. E tratando das operações técnicas lícitas, previa expressamente no artigo 19, como solução para o problema dos conhecimentos fortuitos, que a prova delas resultante só poderia servir em relação aos crimes para os quais a autorização foi dada, com exceção dos crimes conexos ou de qualquer dos outros crimes constantes do catálogo:

Art.19. Os resultados das operações técnicas realizadas nos termos desta lei não poderão ser utilizados para a instrução de processos ou investigações relativos a crimes diversos daqueles para os quais a autorizaçãofoi dada, salvo quando se tratar de crime conexo ou de outro crime constante do art. $1^{\circ}$. desta lei (...).

Merece destaque ainda o PLS 156/2009, de autoria do senador JosÉ SARNEY, fruto de um anteprojeto de reforma global do Código de Processo Penal, elaborado por uma comissão de juristas ${ }^{183}$ criada em julho de 2008, tendo sido o texto acolhido pela Presidência do Senado em meados de 2009, quando então teve início sua tramitação no Congresso Nacional.

O projeto em questão, que passa a trazer para o bojo da codificação o tratamento da interceptação telefônica, peca por não enumerar os crimes passíveis de serem investigados através deste meio de obtenção de prova, limitando-se a prever que a medida não será admitida nos crimes de menor potencial ofensivo, salvo quando a conduta delituosa for realizada exclusivamente por meio dessa modalidade de comunicação. ${ }^{184}$

\footnotetext{
182 A Exposição de Motivos do Anteprojeto foi publicada pela Prof. ${ }^{\text {a }}$ ADA PELLEGRINI GRINOVER, que presidia a comissão, e segundo consta, buscava-se corrigir um dos maiores defeitos da vigente Lei 9.296/96, que consistia "exatamente na inobservância do princípio da proporcionalidade, quando, por exemplo, permite a interceptação relativamente a todos os crimes punidos com pena de reclusão - no que não observa o princípio da adequação e da não-excessividade, estendendo a operação técnica indicada para qualquer tipo de crime, desde que punido com reclusão, e deixando de fora crimes punidos com detenção, mas para os quais a interceptação se apresenta como o meio mais adequado de investigação, como na ameaça cometida por telefone (...)". (Novo anteprojeto de lei que disciplina a quebra de sigilo das comunicações telefônicas. In: Revista Literária de Direito. São Paulo, ano 9, nº 47, p.19-21, jun-jul/2003).

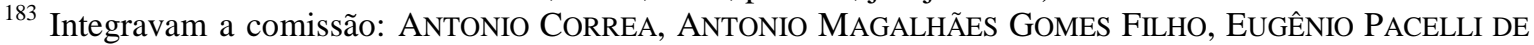
Oliveira, Fabiano Augusto Martins Silveira, Felix Valois CoelHo Júnior, Hamilton CarValhido, Jacinto Nelson de Miranda COUTINHO, SANDro TORRES AVElar e Tito Souza do AMARAL.

184 Redação final do PLS 156/2009: “Art. 247. A interceptação de comunicações telefônicas não será admitida na investigação criminal ou instrução processual de crimes de menor potencial ofensivo, assim definidos no art. 288, salvo quando a conduta delituosa for realizada exclusivamente por meio dessa modalidade de comunicação." e "Art.288. Consideram-se infrações penais de menor potencial ofensivo, para os efeitos deste Código, as contravenções penais e os crimes a que a lei comine pena máxima não superior a 2 (dois) anos, cumulada ou não com multa". (BRASIL. Senado Federal. Redação final do Projeto de Lei do Senado $\quad n^{o} \quad$ 156/2009. Disponível em: <http://www.senado.gov.br/atividade/materia/getPDF.asp?t=85509\&tp=1 >. Acesso em: 14/12/2010).
} 
Além disso, traz apenas uma determinação genérica de que a polícia judiciária, caso descubra, durante o monitoramento telefônico, crime diverso do objeto da investigação e que não lhe seja conexo, deverá enviar a documentação pertinente ao Ministério Público para as "providências cabíveis", sem, no entanto, especificá-las:

Art. 262. Na hipótese de a interceptação das comunicações telefônicas revelar indícios de crime diverso daquele para o qual a autorização foi dada e que não lhe seja conexo, o delegado de polícia deverá remeter ao Ministério Público os documentos necessários para as providências cabíveis. ${ }^{185}$

Em sessão extraordinária realizada no dia 07 de dezembro de 2010, o Plenário do Senado Federal aprovou o projeto de lei, em sua redação final ${ }^{186}$, como o novo Código de Processo Penal, encaminhando-o à apreciação da Câmara dos Deputados, avançando, assim, em seu trâmite legislativo, agora nesta Casa, sob a designação de PL 8.045/2010, onde se espera que a questão seja melhor discutida.

AdA PELLEGRINI GRINOVER critica o regime instituído pelo projeto, pois "Permitir a quebra do sigilo telefônico em relação a todos os crimes, que não sejam de menor potencial ofensivo, não é adequado e infringe a não excessividade. A permissão legal de quebra deve ficar restrita aos crimes em relação aos quais afigura-se necessária, adequada e não excessiva". 187

De fato, melhor seria que o ordenamento jurídico brasileiro enumerasse taxativamente os crimes cuja investigação pode ser realizada mediante a quebra do sigilo telefônico, considerando os crimes mais graves ou que mais se prestam a serem investigados por este meio de obtenção de prova.

$\mathrm{Na}$ redação original do anteprojeto da comissão, o artigo correspondente assim dispunha: “Art.235. A interceptação de comunicações telefônicas não será admitida na investigação ou instrução processual de infrações penais cujo limite mínimo da pena privativa de liberdade cominada seja igual ou inferior a 1 (um) ano, salvo: I - quando a conduta delituosa for realizada exclusivamente por meio dessa modalidade de comunicação; II - no crime de formação de quadrilha ou bando.” (BRASIL. Senado Federal. Comissão de juristas responsável pela elaboração de anteprojeto de reforma do Código de Processo Penal. Anteprojeto. Brasília: Senado Federal, 2009. Disponível em: 〈http://legis.senado.gov.br/mate-pdf/58503.pdf〉. Acesso em: 16/08/2010).

${ }^{185}$ Aqui, o dispositivo manteve a redação original proposta pela comissão no Anteprojeto.

${ }^{186}$ BRASIL. Senado Federal. Redação final... cit.

${ }^{187}$ Do regime das interceptações... op.cit., p.2. 
Daí porque a proposta de emenda apresentada pelo Instituto Brasileiro de Direito Processual (IBDP) ainda ao Senado ${ }^{188}$, sugerindo um catálogo dos crimes que admitiriam a quebra do sigilo das comunicações telefônicas, e que bem lembra aquele catálogo do Anteprojeto elaborado pela Comissão presidida por ADA PELLEGRINI GRINOVER.

Aliás, a proposta abrangia a alteração da redação do dispositivo que trata do conhecimento de crime diverso daquele para o qual a autorização foi dada, também aqui inspirado no Anteprojeto elaborado pela Comissão presidida por ADA PELLEGRINI GRINOVER anos antes. Conforme o proposto pelo Instituto, os resultados das operações técnicas não poderiam ser utilizados para a instrução de processos ou investigações relativos a crimes diversos daqueles para os quais a autorização foi dada, salvo quando se tratasse de crime conexo ou de outro crime constante do catálogo.

Percebe-se que os sistemas que estabelecem catálogos de delitos suscetíveis de justificar a interceptação telefônica (a exemplo de Alemanha e Portugal, que preveem expressamente a lista de crimes para os quais está autorizada a medida) são mais claros para buscar uma solução ao tema dos conhecimentos fortuitos no âmbito deste meio de obtenção de prova.

Por outro lado, registre-se a conveniência de contar o ordenamento nacional, ao menos, com um critério objetivo que limita a interceptação telefônica à persecução de crimes punidos com reclusão. Ainda que não haja um catálogo de crimes, e não represente a melhor opção pelo legislador, conta-se com um critério objetivo baseado na qualidade da pena $^{189}$. Pense-se, por exemplo, no caso da Espanha, em que as interceptações telefônicas estão assentes numa regulamentação legal tão escassa que, na verdade, as indicações legais resumem-se praticamente à indicação da obrigatoriedade da medida de intervenção ser ordenada judicialmente.

Contudo, a existência de um catálogo de crimes que admitem a quebra do sigilo das comunicações telefônicas facilita o estudo de admissibilidade da prova fortuitamente obtida no curso da interceptação, pois, de início, já poderia ser afastada aquela relativa a delito que não integra o rol de tipos que admitem esse meio de investigação. Por isso,

\footnotetext{
${ }^{188}$ BRASIL. Instituto Brasileiro de Direito Processual (IBDP). Comissão de membros do IBDP. Propostas de emendas ao Projeto de Lei de Código de Processo Penal - Substitutivo CCJ do Senado. Relator: Presidência de Ada Pellegrini Grinover. Disponível em: $<$ http://www.novo.direitoprocessual.org.br/content/blocos/96/1>. Acesso em: 20/08/2010.

${ }^{189}$ Lembre-se aqui as críticas feitas no ITEM 3.1.2 quanto à abrangência do critério utilizado pelo legislador, ao autorizar o emprego da interceptação telefônica na apuração de todos os crimes punidos com reclusão.
} 
pode-se afirmar que "A falta, na lei brasileira, de um rol taxativo de infrações em que se admite a interceptação dificulta a solução do problema". ${ }^{190}$

Mas, a questão que se coloca neste ponto é o da necessidade de adoção, no ordenamento brasileiro, de um preceito tal como o $§ 100 \mathrm{~b}$ ), V da StPO no direito alemão, o art.187, $\mathrm{n}^{\circ} 7$ do CPP português, ou o art.270 do CPP italiano, já que não se dispõe, atualmente, de qualquer referência legislativa relativa à problemática dos conhecimentos fortuitos.

Ora, estando em causa a possível violação de direitos fundamentais, constitucionalmente garantidos, o legislador brasileiro tinha que tomar uma posição, a exemplo do que ocorreu na Alemanha (1992) e na Itália (1988) e, mais recentemente, em Portugal (2007). Lamenta-se, portanto, a omissão legislativa nacional.

\subsection{O escasso pronunciamento jurisprudencial}

Encontram-se ainda poucos pronunciamentos nos tribunais pátrios acerca do tema. Pretende-se aqui colacionar algumas dessas decisões, apresentando o caso específico submetido à análise e destacando o tratamento então conferido ao conhecimento fortuito para fins de aproveitamento desta descoberta enquanto prova.

Nos autos de Apelação Criminal no 993.07.104484-9 e 990.09.160391-0, a $6^{\mathrm{a}}$ Câmara Criminal do Tribunal de Justica de São Paulo, sob a relatoria do Desembargador José RAUl GAVIÃo DE ALMEIDA, foi chamada a enfrentar a questão dos conhecimentos fortuitos obtidos em interceptações telefônicas.

No primeiro feito, a recorrente suscitou que a interceptação telefônica tinha sido ilicitamente utilizada contra ela, pois autorizada para a obtenção de prova contra pessoa diversa, mas os julgadores não acolheram a preliminar, constando o seguinte do voto condutor do Acórdão:

A tese da recorrente, de que o teor da conversa interceptada só serve de prova contra aquele que era investigado quando da autorização da

\footnotetext{
${ }^{190}$ GRINOVER; FERNANDES; GOMES FILHO, As nulidades... op.cit., p.175.
} 
interceptação telefônica, é incorreta. A interceptação telefônica autorizada judicialmente nos limites da lei vigente torna lícita a quebra do sigilo telefônico e, consequentemente, legítimo o conhecimento obtido nessa operação. Por isso, toda e qualquer informação sobre infração penal distinta da investigada ou sobre novos envolvidos em ilícitos penais, ainda que obtida fortuitamente, pode ser considerada na apuração dos crimes distintos ou na responsabilização de terceiros. Trata-se da aplicação da teoria do fruto da árvore envenenada às avessas, ou seja, do fruto da árvore saudável. ${ }^{191}$

No segundo feito, também se acolheu a tese da validade da utilização da descoberta fortuita de fatos criminosos, surgida em regular e autorizada interceptação telefônica. Merece destaque o seguinte trecho do voto condutor do Acórdão:

Observe-se que o teor da conversa interceptada não serve de prova apenas contra aquele que era investigado quando da autorização judicial para a violação do sigilo da comunicação telefônica. A interceptação telefônica autorizada judicialmente nos limites da lei vigente torna lícita a quebra do sigilo telefônico e, consequentemente, legítimo o conhecimento obtido nessa operação. Por isso, toda e qualquer informação sobre infração penal distinta da investigada ou sobre novos envolvidos em ilícitos penais, ainda que obtida fortuitamente, pode ser considerada na apuração dos crimes distintos ou na responsabilização de terceiros. Trata-se da aplicação da teoria do fruto da árvore envenenada às avessas, ou seja, do fruto da árvore saudável. ${ }^{192}$

${ }^{191}$ BRASIL. Tribunal de Justiça de São Paulo. 6 a Câmara Criminal. Apelação Criminal no 993.07.104484-9. Relator Desembargador José Raul Gavião de Almeida. Julgado em 11/03/2010. Acórdão disponível em: <https://esaj.tjsp.jus.br/cjsg/getArquivo.do?cdAcordao=4384048>. Acesso em: 09/07/2011.

Ementa: 1- Apelação Criminal - Tráfico de entorpecente. 2 - Utilização do rito da Lei n ${ }^{\circ}$ 6.368/76, após a vigência da Lei $n^{\circ} 10.409 / 02$ - Nulidade relativa, que depende de efetivo prejuízo, não ocorrido na espécie Após a sentença não mais há se falar em defesa preliminar, que antecede o oferecimento da denúncia. 3 Interceptação telefônica. - Teoria do fruto da árvore saudável - Validade da utilização da descoberta fortuita de fatos criminosos em regular e autorizada interceptação telefônica. - Hipótese assemelhada à da descoberta de crime em busca domiciliar autorizada para outra finalidade. 4 - Perícia - Gravações e transcrições realizadas pela polícia. - Atos administrativos que nascem com a presunção de legitimidade. - Cabe à parte o ônus de provar que o serviço apresenta ilicitude ou imprecisão. 5 - Degravação - A necessidade de transcrição está limitada aos diálogos relacionados com a infração e relevantes ao processo (o artigo 184 do Código de Processo Penal prevê o indeferimento da perícia desnecessária) - O que se assegura à parte é o acesso a todas as gravações. - Hipótese em que se facultou cópia integral das gravações em CD-Rom. 6 Materialidade delitiva não impugnada no inconformismo e bem demonstrada pelo auto de apreensão e laudo de exame toxicológico. - Autoria provada por testemunhas policiais e resultado de interceptação telefônica 7Pena bem estabelecida. 8- Preliminares rejeitadas e recurso desprovido.

192 BRASIL. Tribunal de Justiça de São Paulo. 6ª Câmara Criminal. Apelação Criminal no 990.09.160391-0. Relator Desembargador José Raul Gavião de Almeida. Julgado em 21/10/2010. Acórdão disponível em: <https://esaj.tjsp.jus.br/cjsg/getArquivo.do?cdAcordao=4779551>. Acesso em: 09/07/2011.

Ementa: Apelação Criminal - Tráfico de entorpecente. Preliminar de nulidade processual em decorrência das provas terem sido obtidas mediante escuta telefônica e emprestadas de outro processo - Eventual irregularidade na produção de prova não invalida o processo, mas repercute no juízo de mérito com a desconsideração da prova ilícita -Espécie em que as provas foram licitamente obtidas. Nulidade não reconhecida - Interceptação telefônica. Teoria do fruto da árvore saudável - Validade da utilização da descoberta fortuita de fatos criminosos em regular e autorizada interceptação telefônica. Hipótese 
A teoria dos frutos da árvore saudável, como avesso da conhecida teoria dos frutos da árvore envenenada, já vinha sendo adotada pela $6^{\mathrm{a}}$ Câmara Criminal do TJSP, em feitos relacionados a buscas e apreensões. Com efeito, nos autos de Mandado de Segurança $n^{0}$ 990.09.070761-5, inconformado com a decisão de $1^{a}$ instância que indeferiu pedido de liberação de valores monetários apreendidos quando do cumprimento de mandado de busca e apreensão de máquinas caça-níqueis, o impetrante alegava que a apreensão do dinheiro foi ilícita porque não havia autorização judicial para tanto, assim como a apreensão da arma de fogo e das munições, pois estas teriam sido encontradas ao acaso.

A segurança foi denegada pelos julgadores, que, em unanimidade, acolheram o voto do relator, do qual se extrai o seguinte trecho:

\begin{abstract}
Observe-se que não há se falar em ilegalidade na apreensão do dinheiro por não estar expresso no mandado de busca e apreensão. Assim como a arma e munições ilegalmente possuídas puderam ser apreendidas ao serem descobertas em regular atuação policial, também o dinheiro, à vista dos fortes indícios de serem resultado das máquinas caça-níqueis apreendidas, impunha-se apreender. Trata-se a aplicação da teoria do fruto da árvore saudável.

(...)

Não há sentido em restringir a casual descoberta em regular atuação investigativa ou de instrução, em homenagem a direito cuja violação deuse com observância dos parâmetros legais e constitucionais. Se o agente público foi autorizado a realizar determinada diligência, como a de ingressar em residência para proceder a certa apreensão, ou a realizar interceptação telefônica, não se pode pretender dele que finja desconhecer a ilegalidade que para o cumprimento do mandado obrigatoriamente tomou ciência. ${ }^{193}$
\end{abstract}

assemelhada à da descoberta de crime em busca domiciliar autorizada para outra finalidade. Materialidade delitiva comprovada por auto de apreensão do entorpecente e laudo de exame químico-toxicológico. Autoria amparada na confissão do réu José Guedes, na palavra dos policiais federais que investigaram tráfico de entorpecente interestadual e na prisão dos acusados em flagrante. Decisão de primeiro grau ratificada por seus próprios fundamentos - Possibilidade, nos termos do artigo 252 do Regimento Interno do Tribunal de Justiça do Estado de São Paulo. Pena-base motivadamente fixada acima do mínimo legal, com critério de razoabilidade. Impossibilidade de aplicação da causa de redução prevista no artigo 46 da Lei $n^{\circ} 11.343 / 06$ porque o laudo de dependência químico-toxicológico concluiu que o réu Alex tinha condições de se autodeterminar quanto à ilicitude do ato que praticou. Não aplicação da causa de redução prevista no artigo 41 da Lei ${ }^{\circ} 11.343 / 06$ ao recorrente José Guedes, que não colaborou na identificação dos responsáveis pelo tráfico e tentou inocentar os coautores. Inaplicabilidade da causa de redução prevista no parágrafo $4^{\circ}$ do artigo 33 da Lei n 11.343.06 a réus que demonstram dedicação à atividade criminosa e comprometimento com organização criminosa - Considerável quantidade de cocaína transportada pelos réus em tráfico interestadual. Regime prisional fechado em razão de expressa disposição da lei (parágrafo $1^{\circ}$ do artigo $2^{\circ}$ da Lei $\mathrm{n}^{\circ}$ 8.072/90, com a redação dada pela Lei ${ }^{\circ}$ 11.464/2007). Recurso desprovido.

193 BRASIL. Tribunal de Justiça de São Paulo. 6 6 Câmara Criminal. Mandado de Segurança $n^{o}$ 990.09.070761-5. Relator Desembargador José Raul Gavião de Almeida. Julgado em 26/11/2009. Acórdão disponível em: <https://esaj.tjsp.jus.br/cjsg/getArquivo.do?cdAcordao=4228555>. Acesso em: 09/07/2011. 


\section{A $7^{\text {a }}$ Turma do Tribunal Regional Federal da $4^{\mathrm{a}}$ Região, na Apelação Criminal}

$n^{0}$ 2003.70.00.019106-4, de relatoria do Desembargador Federal NÉFI CORDEIRO, decidiu que “(...) As provas encontradas no desenvolvimento da investigação, ainda que conduzam à descoberta acidental de novos crimes ou autores, são de válida utilização na persecução criminal". 194

Do mesmo modo, ao julgar o Agravo de Instrumento $\mathbf{n}^{\mathbf{0}}$ 001168654.2011.404.0000, $4^{\mathrm{a}}$ Turma entendeu que “(...) Não há impeditivo de que a investigação, destinada a apurar determinado fato ilícito, ao realizar a gravação de conversas telefônicas, acabe por identificar outros participantes do concílio delitivo, ainda que originariamente não integrassem o rol de suspeitos". 195

Já no Tribunal Regional Federal da $2^{\mathbf{a}}$ Região, a análise do tema no julgamento do HC 2007.02.01.016145-6 se deu com a diferenciação entre os conhecimentos fortuitos e aqueles chamados de encontros de investigação, para reconhecer a legalidade da prova produzida contra quem não era alvo da interceptação telefônica. O relator destacou em seu voto:

Como se percebe, a interceptação telefônica tinha por foco, a descoberta de todos os integrantes da organização criminosa e o desvendamento do funcionamento da suposta associação, tanto que houve denúncia por crime de quadrilha, daí porque a interceptação que, a princípio, se dirigia a alguns telefones, considerando tratar-se de crime de associação, que pressupõe muitas pessoas, no decorrer das investigações foi se estendendo para outras, até que atingiu o telefone do paciente no início de abril de 2007, descartado, portanto, o "encontro fortuito", sendo certo que a hipótese é mesmo de encontro de investigação (quando na investigação de um fato comum a muitos autores - quadrilha - se vai encontrando em momentos posteriores, referência a outros integrantes da quadrilha que antes ainda não eram objeto da medida).

Ementa: Mandado de Segurança - Interposição com escopo de obter a liberação do numerário e quirógrafo apreendidos pela polícia em busca e apreensão de máquina caça-níqueis. 2. Teoria do fruto da árvore saudável - Sendo legal a atuação policial, eventuais ilícitos nela descobertos e apreensões nela realizadas ficam contaminados pela mesma origem lícita. 3. Inexistência de prova de direito líquido e certo Necessidade de produção de prova sobre a origem do dinheiro. 4. Segurança denegada.

${ }^{194}$ BRASIL. Tribunal Regional Federal da $4^{\mathrm{a}}$ Região. $7^{\mathrm{a}}$ Turma. Apelação Criminal 2003.70.00.019106-4. Relator Desembargador Federal Néfi Cordeiro. Julgado em 21/09/2010. D.E. divulgado em 30/09/2010, publicado em $\quad$ Acórdão disponível em: <http://jurisprudencia.trf4.jus.br/pesquisa/inteiro teor.php?orgao=1\&documento=3362118>. Acesso em: 15/04/2012.

195 BRASIL. Tribunal Regional Federal da $4^{\mathrm{a}}$ Região. $4^{\mathrm{a}}$ Turma. Agravo de Instrumento 001168654.2011.404.0000. Relator Des. Federal Luís Alberto D'Azevedo Aurvalle. Julgado em 24/04/2012. D.E. divulgado em 27/04/2012, publicado em 30/04/2012. Acórdão disponível em: <http://jurisprudencia.trf4.jus.br/pesquisa/inteiro teor.php?orgao=1\&documento=4699505>. Acesso em: 20/08/2012. 


\begin{abstract}
Mas isso não inviabiliza os elementos de prova colhidos, obtidos por meio da interceptação de conversas de outros alvos, nas quais o paciente aparece como interlocutor, porque, como é óbvio ululante um determinado alvo de interceptação telefônica, haverá de se comunicar com outras pessoas e se nestas comunicações aparecem traços da prática de ilícito de concurso necessário, como o de quadrilha, por certo que deverão ser levados em consideração, tanto em relação ao alvo como em relação ao interlocutor. ${ }^{196}$
\end{abstract}

No Superior Tribunal de Justiça já se admitiu prova de crime diverso, obtida por meio de interceptação telefônica de terceiro não mencionado na autorização judicial, desde que relacionada com o fato criminoso objeto da investigação. Nesse sentido, o julgamento dos autos de HC 33.553 $^{197}$ e HC 33.462 $^{198}$, ambos de relatoria da Ministra LAURITA VAZ: “(...) É lícita a prova de crime diverso, obtida por meio de interceptação de ligações telefônicas de terceiro não mencionado na autorização judicial de escuta, desde que relacionada com o fato criminoso objeto da investigação".

Importante exceção posta pelo Superior Tribunal de Justiça quanto à necessidade de constatação dessa relação entre o fato investigado e o fato encontrado fortuitamente se deu no âmbito do julgamento do HC 69.552. No caso, admitiu-se a validade da prova fortuitamente colhida durante interceptação telefônica decretada para apurar outros crimes, dispensando-se o requisito da conexão, eis que os crimes descobertos se referiam à atividade criminal futura, e que, portanto, o Estado não poderia quedar-se inerte. Vale destacar o seguinte trecho da ementa:

196 BRASIL. Tribunal Regional Federal da $2^{\mathrm{a}}$ Região. $1^{\mathrm{a}}$ Turma especializada. Habeas Corpus 2007.02.01.016145-6. Relator Desembargador Federal Abel Gomes. Julgado em 23/07/2008. DJU 13/08/2008, p.64. Acórdão disponível em: $\underline{\text { http://www.trf2.gov.br/cgi- }}$ bin/pdbi?PRO=200702010161456\&TOPERA=1\&I1=OK>. Acesso em: 15/04/2012.

Ementa: (...) I - PROCESSO PENAL. HABEAS CORPUS. (...) V - INTERCEPTAÇÕES TELEFÔNICAS. PROVAS. LEGALIDADE. (...) VII - DENEGAÇÃO DA ORDEM. (...) IV - Na investigação de um fato comum a muitos autores se vai encontrando, em momentos posteriores, referência a outros integrantes da quadrilha que antes ainda não eram objeto da medida. Hipótese de encontro de investigação não inviabiliza os elementos de prova colhidos obtidos por meio da interceptação de conversas de outros alvos, nas quais o paciente aparece como interlocutor. Escutas realizadas com autorização judicial e, ao que tudo indica, não destoaram do foco das investigações. Permitido às partes o acesso à prova e ao contraditório. Ilegalidade não constatada.(...) IX - Denegação da ordem.

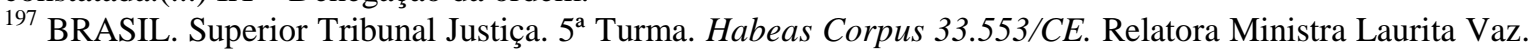
Julgado em 17/03/2005. DJ 11/04/2005, p.338. Acórdão disponível em: <https://ww2.stj.jus.br/revistaeletronica/Abre Documento.asp?sSeq=534863\&sReg=200400152006\&sData= 20050411\&formato=PDF $>$. Acesso em: 09/07/2011.

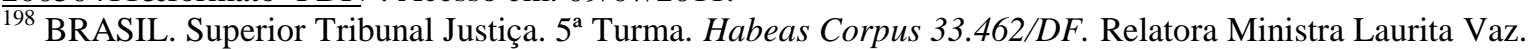
Julgado em 27/09/2005. DJ 07/11/2005, p. 316. Acórdão disponível em: <https://ww2.stj.jus.br/revistaeletronica/Abre Documento.asp?sSeq=582592\&sReg=200400136129\&sData= 20051107\&formato=PDF>. Acesso em: 13/07/2011. 
PENAL E PROCESSUAL PENAL. HABEAS CORPUS SUBSTITUTIVO DE RECURSO ORDINÁRIO. ART. 288 DO CÓDIGO PENAL. INÉPCIA DA DENÚNCIA OFERECIDA EM DESFAVOR DOS PACIENTES BASEADA EM MATERIAL COLHIDO DURANTE A REALIZAÇÃO DE INTERCEPTAÇÃO TELEFÔNICA PARA APURAR A PRÁTICA DE CRIME DIVERSO. ENCONTRO FORTUITO. NECESSIDADE DE DEMONSTRAÇÃO DA CONEXÃO ENTRE O CRIME INCIALMENTE INVESTIGADO E AQUELE FORTUITAMENTE DESCOBERTO. I - Em princípio, havendo o encontro fortuito de notícia da prática futura de conduta delituosa, durante a realização de interceptação telefônica devidamente autorizada pela autoridade competente, não se deve exigir a demonstração da conexão entre o fato investigado e aquele descoberto, a uma, porque a própria Lei n ${ }^{\circ}$ 9.296/96 não a exige, a duas, pois o Estado não pode se quedar inerte diante da ciência de que um crime vai ser praticado e, a três, tendo em vista que se por um lado o Estado, por seus órgãos investigatórios, violou a intimidade de alguém, o fez com respaldo constitucional e legal, motivo pelo qual a prova se consolidou lícita. II - A discussão a respeito da conexão entre o fato investigado e o fato encontrado fortuitamente só se coloca em se tratando de infração penal pretérita, porquanto no que concerne as infrações futuras o cerne da controvérsia se dará quanto a licitude ou não do meio de prova utilizado e a partir do qual se tomou conhecimento de tal conduta criminosa. Habeas corpus denegado. ${ }^{199}$

Merece referência também o decidido pela Corte Especial do STJ no âmbito da Ação Penal no 425 sobre o conhecimento de elementos de suposta ilicitude, paralela aos temas investigados, no curso de uma interceptação telefônica. Em seu voto, acolhido por unanimidade com relação a essa preliminar, o relator Ministro José ARNALDO DA FONSECA destacou:

(...) se a captação, dentro dos padrões legais, mostrou uma realidade nova em torno dos envolvidos e terceiros até então não identificados, e sobre fatos diversos por extensão, nada impede que estes possam sustentar uma persecução autônoma, porque, repita-se, o que importa é considerar as interceptações telefônicas condizentes com os ditames do artigo $5^{\circ}$, inciso XII, da Constituição Federal, bem assim, da Lei n ${ }^{\circ}$ 9.296, de 24 de julho de $1996 .{ }^{200}$

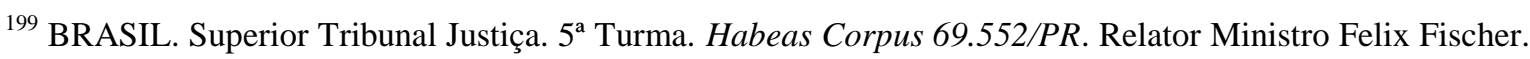
Julgado em 06/02/2007. DJ 14/05/2007, p.347. Acórdão disponível em: $<$ https://ww2.stj.jus.br/revistaeletronica/Abre Documento.asp?sSeq=671032\&sReg=200602419935\&sData= 20070514\&formato=PDF>. Acesso em: 09/07/2011. (sem grifos no original)

200 BRASIL. Superior Tribunal Justiça. Corte Especial. Ação Penal 425/ES. Relator Ministro José Arnaldo da Fonseca. Julgado em 16/11/2005. DJ 15/05/2006, p. 141. Acórdão disponível em: $<$ https://ww2.stj.jus.br/revistaeletronica/Abre Documento.asp?sSeq=593161\&sReg=200501126738\&sData= 20060515\&formato=PDF>. Acesso em: 13/07/2011. Cumpre destacar o seguinte trecho da ementa: “(...) A captação de conversas telefônicas obtidas dentro dos padrões legais, mesmo que aclarando realidade nova, pode sustentar uma persecução autônoma, ainda mais quando o seu conteúdo se mostrar fiel ao transcurso
} 
Nos autos de HC 15.1530, o tribunal superior foi novamente provocado a se manifestar sobre o tema quando o impetrante suscitou a nulidade de processo-crime, sob a alegação de que a denúncia contra ele oferecida baseava-se em provas ilícitas em razão de indevida ampliação do objeto do mandado judicial quando do cumprimento de diligência, eis que o mesmo tinha por finalidade específica a busca e apreensão da arma utilizada no crime de lesão corporal gravíssima.

De fato, no caso analisado, o objeto do mandado era específico para a busca e apreensão de arma de fogo, e durante o cumprimento da diligência foi apreendida grande quantidade de substâncias hormonais e remédios de uso veterinário, além de seringas, agulhas, algemas e placas avulsas de automóveis. No entanto, os Ministros consideraram legal a apreensão dos objetos, afastando a tese do impetrante, conforme se extrai do seguinte trecho da ementa:

HABEAS CORPUS. (...) AFIRMAÇÃO DE QUE A DENÚNCIA BASEOU-SE EM PROVAS ILÍCITAS, EM RAZÃO DE INDEVIDA AMPLIAÇÃO DO OBJETO DO MANDADO JUDICIAL QUANDO DO CUMPRIMENTO DE DILIGÊNCIA. EXPEDIÇÃO UNICAMENTE PARA BUSCA E APREENSÃO DA ARMA USADA PELO PACIENTE. TESE NÃO ACOLHIDA. SITUAÇÃO DE FLAGRÂNCIA. POSSIBILIDADE DE SE RECOLHEREM BENS EVIDENTEMENTE UTILIZADOS PARA O COMETIMENTO DE CRIMES. NULIDADE NÃO VERIFICADA QUANTO A ESTE TOCANTE. PRECEDENTES (...). Não se acolhe a alegação de denúncia baseada em provas ilícitas quando, da realização de diligência para a busca e apreensão de bem específico, recolhem-se também objetos que, flagrantemente, são utilizados para o cometimento de outros crimes. Segundo recente julgamento do Supremo Tribunal Federal, seria ilícita apenas a apreensão de objetos "que se reportam a circunstâncias remotas, dissociadas do contexto atual" (HC 95.009/SP, Tribunal Pleno, Rel.Min. EROS GRAU, DJe de 19/12/2008), o que, nem de longe, ocorre na hipótese. Assim, a apreensão de coisas que, sem maiores exercícios, são utilizadas para a prática de crimes, é plenamente admissível - no caso, v.g., grande quantidade de substâncias anabolizantes, remédios de uso veterinário, seringas e agulhas, um par de algemas manchado de sangue humano. Aliás, ilógico e irracional seria admitir o contrário. (...) Nulidade não verificada quanto a esta alegação. ${ }^{201}$

da investigação originária. Inteligência do artigo $5^{\circ}$, inciso XII, da Constituição Federal, bem assim, da Lei $n^{\circ}$ 9.296/96."

201 BRASIL. Superior Tribunal Justiça. 5a Turma. Habeas Corpus 151.530/PB. Relatora Ministra Laurita Vaz. Julgado em 18/05/2010, DJe 14/06/2010. Acórdão disponível em: <https://ww2.stj.jus.br/revistaeletronica/Abre Documento.asp?sSeq=972154\&sReg=200902083349\&sData= 20100614\&formato=PDF>. Acesso em: 09/07/2011. 
No âmbito do Tribunal Pleno do Supremo Tribunal Federal, o Ministro SEPÚlveda Pertence enfrentou o tema em voto proferido nos autos de HC 81.260, em que se discutia a licitude da prova resultante de interceptação telefônica quando a autorização da medida se dá por juiz que posteriormente se declara incompetente, uma vez que o delito descoberto não se compreende na sua esfera de competência:

\begin{abstract}
Aludo ao problema dos "conhecimentos fortuitos", concernente a saber em que hipóteses e em que medida será lícito utilizar-se, como prova, da informação colhida - mercê da interceptação telefônica autorizada -, a respeito de fatos delituosos àqueles para a averiguação dos quais se emitiu a autorização. Não é o momento de analisar as soluções aventadas para a questão pela jurisprudência e a doutrina comparadas - a exemplo da germânica, que o professor coimbrão resenha, e da espanhola, a que se reporta o jurista uruguaio. Basta observar que é francamente minoritária, entre os tribunais e os doutores, a recusa peremptória da licitude da "prova encontrada", parecendo dominante, pelo contrário, a dos que concluem por sua admissibilidade, desde, pelo menos, que o fato desvelado fortuitamente se encontre entre os chamados "crimes de catálogo" - isto é, entre aqueles para a investigação dos quais se permite autorizar a interceptação telefônica. Nesse quadro, parece manifesto que seria um contra-senso sujeitar a licitude da prova casualmente captada a que o delito descoberto se compreendesse na competência do juiz que, com vistas à averiguação da suspeita de um outro - compreendido na sua esfera de jurisdição - houvesse autorizado legitimamente a interceptação. ${ }^{202}$
\end{abstract}

O problema do aproveitamento dos elementos de prova relacionados a um crime punido com detenção, descoberto fortuitamente no decorrer de uma interceptação, não passou despercebido pelos Ministros do Pretório Excelso. Com efeito, no julgamento do HC 83.515, reconheceram por unanimidade a licitude da prova de outro crime, diverso daquele investigado, obtida por meio de interceptação telefônica autorizada, de início, para apuração de crime punido com reclusão, sob o argumento de que a conexão entre os fatos e os crimes justificaria a licitude e aproveitamento da prova:

Uma vez realizada a interceptação telefônica de forma fundamentada, legal e legítima, as informações e provas coletas dessa diligência podem subsidiar denúncia com base em crimes puníveis com pena de detenção, desde que conexos aos primeiros tipos penais que justificaram a interceptação. Do contrário, a interpretação do art. $2^{\circ}$, III, da L. 9.296/96

202 BRASIL. Supremo Tribunal Federal. Tribunal Pleno. Habeas Corpus 81.260/ES. Relator Ministro Sepúlveda Pertence. Julgado em 14/11/2001. DJ 19/04/2002, p.48. Acórdão disponível em: <http://redir.stf.jus.br/paginadorpub/paginador.jsp?docTP=AC\&docID=78672>. Acesso em: 13/07/2011. 
levaria ao absurdo de concluir pela impossibilidade de interceptação para investigar crimes apenados com reclusão quando forem estes conexos com crimes punidos com detenção. ${ }^{203}$

Entendimento este mantido quando do julgamento do Agravo Regimental em Agravo de Instrumento $\mathbf{n}^{\mathbf{0}}$ 626.214, cuja ementa se transcreve:

\begin{abstract}
AGRAVO REGIMENTAL EM AGRAVO DE INSTRUMENTO. INTERCEPTAÇÃO TELEFÔNICA LICITAMENTE CONDUZIDA. ENCONTRO FORTUITO DE PROVA DA PRÁTICA DE CRIME PUNIDO COM DETENÇÃO. LEGITIMIDADE DO USO COMO JUSTA CAUSA PARA OFERECIMENTO DE DENÚNCIA. AGRAVO REGIMENTAL DESPROVIDO. 1. O Supremo Tribunal Federal, como intérprete maior da Constituição da República, considerou compatível com o art. $5^{\circ}$, XII e LVI, o uso de prova obtida fortuitamente através de interceptação telefônica licitamente conduzida, ainda que o crime descoberto, conexo ao que foi objeto da interceptação, seja punido com detenção. 2. Agravo Regimental desprovido. ${ }^{204}$
\end{abstract}

Ainda no âmbito do STF, se alegava no HC 84.388 desvio de finalidade nas interceptações telefônicas, o que teria implicado conhecimento não autorizado de crime diverso no bojo da chamada Operação Anaconda. De fato, segundo consta do voto emitido pelo Ministro JOAQUim BARBOSA, o impetrante sustentava que a prova produzida pelas escutas era ilícita "na medida em que os supostos fatos criminosos imputados ao paciente se tornaram conhecidos de forma fortuita, estranha, portanto, ao objeto das investigações que autorizaram as interceptações telefônicas". O relator, ao esclarecer que a medida realizada tinha como objetivo apurar suspeita de envolvimento de magistrados em práticas de corrupção, notadamente a venda de sentenças, na verdade entendeu que sequer se tratava de conhecimento fortuito, pois os fatos imputados ao paciente - juiz federal - não estavam dissociados do objetivo das interceptações telefônicas. ${ }^{205}$

\footnotetext{
${ }^{203}$ BRASIL. Supremo Tribunal Federal. Tribunal Pleno. Habeas Corpus 83.515/RS. Relator Ministro Nelson Jobim. Julgado em 16/09/2004. DJ 04/03/2005, p.11. Acórdão disponível em: $\langle$ http://redir.stf.jus.br/paginadorpub/paginador.jsp?docTP=AC\&docID=79377>. Acesso em: 09/07/2011.

204 BRASIL. Supremo Tribunal Federal. $2^{\mathrm{a}}$ Turma. Agravo Regimental em Agravo de Instrumento 626.214/MG. Relator Ministro Joaquim Barbosa. Julgado em 21/09/2010. DJe-190, divulgado em 07/10/2010, publicado em 08/10/2010. Acórdão disponível em: $<$ http://redir.stf.jus.br/paginadorpub/paginador.jsp?docTP=AC\&docID=615361 >. Acesso em: 09/07/2011.

${ }^{205}$ BRASIL. Supremo Tribunal Federal. $2^{\mathrm{a}}$ Turma. Habeas Corpus $84.388 / \mathrm{SP}$. Relator Ministro Joaquim Barbosa. Julgado em 26/10/2004. DJ 19/05/2006, p.42. Acórdão disponível em: $\langle$ http://redir.stf.jus.br/paginadorpub/paginador.jsp?docTP=AC\&docID=79578>. Acesso em: 09/07/2011.

Ementa: HABEAS CORPUS. "OPERAÇÃO ANACONDA". INÉPCIA DA DENÚNCIA. ALEGAÇÕES DE NULIDADE QUANTO ÀS PROVAS OBTIDAS POR MEIO ILÍCITO. INTERCEPTAÇÃO
} 
Verifica-se que algumas decisões admitem que toda e qualquer informação sobre infração penal distinta da investigada ou sobre novos envolvidos em ilícitos penais, ainda que obtida fortuitamente, pode ser considerada na apuração dos crimes distintos ou na responsabilização de terceiros.

Mas, pelo que se percebe, há uma tendência na jurisprudência nacional de se outorgar validez ao descobrimento de condutas ilícitas durante um monitoramento telefônico e durante a execução de um mandado de busca, mas exigindo para tanto que o conhecimento fortuito esteja relacionado com o fato criminoso objeto da investigação, ou lhe seja conexo. 


\section{ANÁLISE DOS CONHECIMENTOS OBTIDOS EM INVESTIGAÇÃO POR CRIME DIVERSO}

Uma vez que se está em busca de um critério suscetível de determinar o âmbito de admissibilidade dos conhecimentos fortuitos, já se imagina que o caminho a seguir impõe que não se extremem posições defendendo ora a admissibilidade irrestrita do resultado ora a negação total de qualquer conhecimento fortuito.

Mas, é que antes, pretende-se ponderar sobre as soluções extremas propostas para o tratamento processual destes conhecimentos fortuitos, para as quais não importam distinções entre descobrimento de delitos conexos ao investigado e aqueles absolutamente independentes. Aliás, reside aí a maior crítica aos que defendem a negação absoluta dos conhecimentos fortuitos ou sua valoração apriorística, sem restrições.

\subsection{Negação absoluta dos conhecimentos fortuitos ou sua valoração sem restrições?}

Deverão todos os conhecimentos fortuitos, não obstante, ser admitidos no processo e valorados? Ou, pelo contrário, deverá a valoração dos mesmos ser pura e simplesmente recusada? As posições extremas têm seus seguidores.

Por um lado, os que defendem a tese segundo a qual, em nome da reserva de lei para a restrição de direitos fundamentais, há de negar-se a admissibilidade de todo e qualquer conhecimento fortuito, da qual era representante, na Alemanha, PRITTWITZ, para quem a valoração devia limitar-se precisamente àqueles crimes em nome dos quais foi concretamente ordenada a medida restritiva. ${ }^{206}$

Porém, essa teoria da irrelevância jurídica dos conhecimentos fortuitos perdeu o sentido, no quadro da doutrina alemã, pela positivação da valoração destes no âmbito das interceptações telefônicas, por meio da já mencionada Lei de Combate ao Tráfico Ilegal de Estupefacientes e outras formas de Criminalidade Organizada.

${ }^{206}$ AGUILAR, Dos conhecimentos fortuitos... op.cit., p.44-45. 
O autor argentino CARlos Alberto CARBone, comentando sobre o princípio da especialidade, esclarece que:

La escasa doctrina, al poner el acento en el principio referido, es escéptica en validar los hallazgos casuales porque el derecho a la intimidad de los sujetos pasivos únicamente cede para posibilitar la incautación de aquello que el juez autorizó y específicamente para el caso que señala o para grabar una conversación vinculada al objeto de la investigación, debiendo ser excluidos los resultados de estas medidas producto de la conducta policial. ${ }^{207}$

$\mathrm{Na}$ doutrina nacional assume esta posição DAMÁSIO DE JESUS, para quem o resultado da interceptação telefônica que leva ao conhecimento fortuito de outro crime, situação que denomina de "novação do objeto da autorização; forma de aberratio deliciti", não vale como prova ou material de investigação, sendo nulo de pleno direito. ${ }^{208}$ Inadmissível, segundo Cleunice PITOMBO, aceitar-se a legalidade da prova introduzida nos autos, por meio da apreensão do que nenhuma relação tenha com o perquirido. ${ }^{209}$

Do mesmo modo, CAMARgo ARANHA defende que a prova encontrada fortuitamente não poderá ser, de forma alguma, utilizada no processo, já que não estava prevista na investigação e, tampouco, na autorização proferida pela autoridade judicial. Justifica este autor que a prova obtida com o cumprimento destas diligências deve corresponder ao fundamento apresentado e que serviu de base para a decisão autorizadora da medida, pois:

Fora de tal hipótese, estar-se-ia usando de uma prova ilícita quanto ao modo em que colhida, porque fugiu dos preceitos legais que exigem um pedido com fundamentação certa, contra pessoa determinada, e que, como tal, serviu de base à autorização judicial concedida. Estar-se-ia burlando a própria fundamentação da autorização judicial. ${ }^{210}$

\footnotetext{
${ }^{207}$ Requisitos constitucionales... op.cit., p.372.

208 Interceptação de comunicações... op.cit., p.467. Mas o autor admite a validade da prova em relação a terceiros quando surgem como coautores ou partícipes do crime investigado.

${ }^{209}$ Licitude da prova obtida por meio da busca e da apreensão. In: VILARDI, Celso Sanchez; BRESSER, Flavia Rahal; DIAS NETO, Theodomiro (Coord.). Direito penal econômico: crimes econômicos e processo penal. Série GV law. São Paulo: Saraiva, 2008. p.57.

${ }^{210}$ Da prova... op.cit., p. 295.
} 
Luiz Vicente CERnicChiaro é enfático em declarar que a prova colhida com a interceptação só pode ser utilizada na hipótese mencionada no requerimento de autorização judicial, ou seja, "ela é imprestável para outro inquérito ou outro processo". ${ }^{211}$

Mas, ainda que o rigor do princípio da especialidade imponha que o suposto crime investigado deva constituir o exclusivo objeto da diligência a ser realizada, isto não significa que não se possa pensar em um critério que bem identifique quando e como a prova oriunda de investigação por crime diverso pode ser admitida e valorada na apuração do delito conhecido fortuitamente.

No outro extremo, no âmbito das teses doutrinais que admitem a valoração dos conhecimentos fortuitos, cabe aludir, neste momento, à posição defensora da sua valoração sem restrições, como o fez SCHÜNEMANN, em nome do postulado da continuidade entre a licitude da produção de uma prova e a legitimidade de sua valoração. $^{212}$

É a opinião de PAUlo RANGEL, que declara não ter dúvidas quanto à licitude na obtenção do conhecimento fortuito de outros fatos ocasionados pela interceptação lícita, pois, segundo o autor, "do contrário, seria entendermos que do lícito adveio o ilícito". ${ }^{213}$

Ora, a figura do encontro fortuito está atrelada à obtenção de provas através de um meio ofensivo a direitos fundamentais pessoais - a reserva da intimidade, da vida privada, inviolabilidade das comunicações e do domicílio - consagrados constitucionalmente, mas, para EUGÊNIO PACELli DE OLIVEIRA, por exemplo, uma vez franqueada a violação dos direitos à privacidade e à intimidade, não há razão para a recusa de provas de quaisquer outros delitos. ${ }^{214}$ Afinal, com o rejeitar dessa prova, não se restaura a privacidade, que já teria sido violada no momento em que o juiz autorizou o ingresso na casa do investigado ou a interceptação do seu telefone em busca do crime investigado.

De fato, consoante JUAN TAPIA, o argumento dos defensores da valoração total dos conhecimentos fortuitos se baseia na concepção de que

\footnotetext{
${ }^{211}$ Lei 9.296/96: interceptação telefônica. In: Boletim IBCCRIM. São Paulo, no 47, p. 03, out./1996.

${ }^{212}$ ANDRADE, Sobre as Proibições... op.cit., p.309.

${ }^{213}$ Breves considerações sobre a Lei n ${ }^{\circ}$ 9.296/96: interceptação telefônica. In: Revista Brasileira de Ciências Criminais, São Paulo, n ${ }^{\circ}$ 26, p.143-151. abr-jun/1999. p.147.

${ }^{214}$ Curso de Processo Penal... op.cit., p.315.
} 
(...) mientras dura la diligencia judicial se encuentra legalmente restringido el derecho a la intimidad, de modo que resulta válida tanto la actuación policial en lo que concierne al secuestro de elementos no precisados en la orden de allanamiento, pero posiblemente relacionados con otro ilícito, como la grabación de manifestaciones verbales que escapan al contenido de los diálogos que se pretendía escuchar pero permite inferir la existencia de un nuevo injusto, resultando estos elementos aptos para su valoración en perjuicio de los participes en los nuevos hechos. ${ }^{215}$

Para este mesmo autor, esse entendimento, que domina a jurisprudência argentina, e cuja origem remonta a um precedente da Corte Suprema daquele país ${ }^{216}$, parte de uma premissa equivocada, de que "la orden jurisdiccional que habilita la injerencia estatal suprime el derecho a la intimidad durante su ejecución”, quando na verdade o direito à intimidade somente se encontra "restringido con el único objeto de permitir que las agencias policiales obtengan los medios de prueba previamente identificados y taxativamente precisados."217

Ora, ao se admitir a valoração probatória de todo e qualquer conhecimento fortuito advindo da investigação de crime diverso, estar-se-ia admitindo que a simples emissão de um mandado judicial autorizaria a interceptação de prospecção ou - no caso da busca e apreensão - uma ampla devassa no interior da residência, permitindo a apreensão de tudo que fosse encontrado.

Parte-se, então, em busca de um critério suscetível de determinar o âmbito de admissibilidade dos conhecimentos fortuitos no sistema processual penal brasileiro, a partir do já exposto sobre o tema no Direito Comparado, e levando em consideração as diversas manifestações encontradas na doutrina e jurisprudência nacional sobre a problemática, sobretudo, em razão do silêncio legislativo quanto à solução jurídica da questão.

\footnotetext{
${ }^{215}$ Descubrimientos accidentales... op.cit., p.672.

${ }^{216}$ Precedente $D$ 'Acosta da Corte Suprema de Justicia de la Nación: "mientras dura la diligencia (en el caso, registro domiciliario) se encuentra enervado el derecho de exclusión del habitante de la morada, de modo que carecerían de eficacia las objeciones que pretendiera oponer a cualquier acto que constituyera una ampliación del objeto de la pesquisa, porque su intimidad ha sido en concreto desguarnecida por mandato judicial". (Ibid., p.672).

${ }^{217}$ Ibid., p.673.
} 


\subsection{Critério adotado: âmbito de admissibilidade dos conhecimentos obtidos em investigação de crime diverso}

Já se sabe que o caminho a seguir impõe que não se extremem posições defendendo ora a admissibilidade irrestrita do resultado ora a negação total de qualquer conhecimento obtido fortuitamente através da restrição de um direito fundamental autorizada judicialmente para finalidade distinta.

As soluções oferecidas pela doutrina e jurisprudência alemã e portuguesa não podem ser simplesmente trasladadas ao direito processual penal brasileiro, dado que o ordenamento jurídico de ambos os países, conforme já retratado, preveem um catálogo de delitos que permitem a autorização de uma interceptação telefônica para sua investigação e possível acusação (art.187, nº do CPP português e $\$ 100 a$ da StPO alemã): “Trata-se de uma enumeração taxativa e fechada através da qual tanto o legislador alemão como o português procuraram plasmar e dar expressão positivada ao juízo de proporcionalidade". ${ }^{218}$

Afinal, é sobre este pressuposto limitador, por meio do qual o legislador estrangeiro ponderou o direito constitucional ao sigilo das comunicações, que a questão dos encontros fortuitos é enfrentada nas jurisprudências e doutrinas alemã e portuguesa, e que serviu de parâmetro para as previsões legislativas em vigor, no sentido de admitir a valoração dos conhecimentos fortuitos desde que se reportem a um dos crimes catalogares. Como bem adverte TORQuATO Avolio, no contexto da lei nacional vigente, "seria mesmo absurdo admitir que a prova colhida em investigação sobre crime determinado pudesse servir como prova de qualquer outro delito punido com reclusão". ${ }^{219}$ Não obstante, é possível buscar uma base teórica em seus critérios para a adoção de uma solução.

Já o ordenamento jurídico italiano, embora também enumere os crimes passíveis de serem investigados por este meio de obtenção de prova, revela-se exageradamente amplo ao permitir a utilização dos resultados das interceptações de comunicações telefônicas em outros procedimentos quando relativos a crimes nos quais é obrigatória a prisão em flagrante.

Sinalizando para uma proposta semelhante ao critério adotado na Espanha, SERGIO Moro sugere que, desde que o encontro fortuito seja comunicado ao juiz, por meio

\footnotetext{
${ }^{218}$ ANDRADE, Sobre as Proibições... op.cit., p.290.
}

${ }^{219}$ Provas ilícitas..., op.cit., p.233. 
de uma ampliação da autorização judicial o crime descoberto poderá passar a ser investigado:

Desde que não haja má-fé, as provas colhidas fortuitamente em uma diligência de busca e apreensão ou pelo emprego de um método especial de investigação devem ser consideradas válidas.

Certamente, o encontro fortuito deve ser sempre comunicado ao juiz, que, dependendo do caso, poderá ampliar, por nova decisão, a extensão da busca ou dos limites inicialmente postos na decisão que autorizou o emprego do método especial de investigação. Assim, se, em uma interceptação telefônica judicialmente autorizada para apurar crimes de roubo, colhem-se provas de crime de tráfico, deve a autoridade policial informar o fato ao juiz e solicitar autorização para utilização das provas: inclusive, se houver requerimento de prorrogação da interceptação, deve solicitar autorização para que a diligência possa colher, a partir daí, também provas do crime fortuitamente descoberto. ${ }^{220}$

Também não parece ser essa a melhor solução, pois não é de se cogitar, consoante adverte LUIZ FlaVio GOMES, “de extensão ou ratificação a posteriori pelo juiz. Isso não existe no nosso direito, que adotou o critério da verificação a priori" ${ }^{221} \mathrm{E}$ tal solução redundaria em uma interceptação prospectiva, em que se legitima o encontro fortuito pelo resultado positivo da diligência, o que não se admite.

O caminho percorrido impõe que se defenda a adoção de um critério suscetível de determinar o âmbito de admissibilidade dos conhecimentos obtidos em investigação de crime diverso, compatível com o sistema processual penal brasileiro, para fins de seu aproveitamento, esclarecendo afinal, que valor deve outorgar-se a esses conhecimentos.

\subsubsection{A admissibilidade dos conhecimentos fortuitos a partir do critério de definição da competência por conexão e continência}

A busca domiciliar deve estar previamente justificada pelos elementos da investigação preliminar e voltada para o descobrimento do que se procura, daí porque a necessidade de se indicar no mandado o motivo e os fins da diligência (art.243, inc.II,

${ }^{220}$ Crime de lavagem de dinheiro. São Paulo: Saraiva, 2010. p.129.

${ }^{221}$ Interceptação telefônica: Lei 9.296/96... op.cit., p.195. 
CPP), que constituem o núcleo da autorização judicial. A ordem, assim, vincula a busca àquilo que interessa para comprovação do delito que está sendo investigado, pois o ato judicial que autoriza a medida excepcional é limitado ao contexto jurídico e fático em que ela foi deferida, estando restrita à apuração do crime que ensejou a decisão.

Por isso, vale lembrar o observado no ITEM 3.2.2 quanto à necessidade de se definir claramente no mandado o que se busca e a qual fato supostamente criminoso o objeto da apreensão deve estar vinculado, em crítica ao que ocorre muitas vezes na prática forense, com determinações genéricas de busca e apreensão, deixando à discricionariedade da autoridade policial os objetos a serem apreendidos, transformando a ordem em um tipo de expedição de pesca com a finalidade de encontrar qualquer coisa que possa revelar a existência de um crime.

Sobre a interceptação telefônica, também retomando as considerações já expostas, no ITEM 3.1.2, tem-se que o artigo $2^{\circ}$, parágrafo único, da Lei ${ }^{\circ}$ 9.296/96, ao estabelecer os requisitos para a decretação judicial desse meio de obtenção de prova, exige, dentre outras formalidades, uma delimitação da base fática da medida (relacionada à descrição com clareza da situação objeto da investigação). E, quanto ao sujeito passivo da providência restritiva, a decisão judicial deve também indicar o alvo da investigação, até porque contra este residem os indícios razoáveis da autoria ou participação em infração penal punida com reclusão. Nesse contexto, é que se articula a ideia de que a investigação deve se ater ao objeto delimitado na decisão permissiva do meio de obtenção de prova.

De fato, sob o rigor do princípio da especialidade, impõe-se que o suposto crime investigado deva constituir o exclusivo objeto da diligência a ser realizada. Mas, como observa LENIO STRECK ao tratar da interceptação telefônica, embora o raciocínio aproveite a hipótese de mandados de busca, essa exigência na verdade visa evitar devassas na intimidade de pessoas sem que haja fatos concretos a investigar: "o objetivo da Lei é evitar que se faça autorizações no atacado, para tentar descobrir delitos e autores no varejo". 22

Em virtude disso, e como menciona SCARANCE FERNANDES, parte da doutrina procura situar a questão dos conhecimentos fortuitos em um ponto médio, concebendo a ilicitude da prova por desvio do objeto da interceptação ou da busca autorizada judicialmente, mas considerando que nem toda prova obtida em relação a crime diverso

${ }^{222}$ As interceptações... op.cit., p.124. 
daquele da autorização será ilícita: “o critério para afirmação da licitude deve ser o da existência de nexo entre o crime descoberto e o crime investigado". 223

Este critério permite que a prova obtida a partir do desvio causal seja admitida no processo, desde que se refira a um crime relacionado àquele que motivou a autorização da medida, pois a sua origem estará dentro de uma prova lícita.

LENIO STRECK, por exemplo, entende não haver problema na utilização da prova relacionada ao crime descoberto fortuitamente desde que esteja dentro de "uma cadeia de fatos atribuídos ao(s) autor(es) cujas comunicações telefônicas foram interceptadas". 224 Sugere, enfim, que haja uma relação causal com o objeto da investigação que motivou a autorização interceptativa, pois fora dessa cadeia de fatos e autores investigados, o conhecimento obtido será tão somente conformador de um indício para, por exemplo, fundamentar um novo pedido de interceptação que diga respeito a esse fato. ${ }^{225}$

Tratando especificamente das buscas domiciliares, FABIO MOTTA LOPES destaca a necessidade de que exista uma relação entre aquilo que o magistrado determinou que se buscasse com as coisas que foram, de fato, encontradas, pois, "do contrário, se a localização casual de objetos estiver dissociada do contexto que originou a busca, a prova deverá ser classificada como ilícita (...)". ${ }^{226}$

Questionando a possibilidade de aproveitamento da prova obtida por meio da interceptação em relação à pessoa não mencionada na autorização judicial, ADA PELEGRINI GRINOVER, SCARANCE FERNANDES e MAGALHÃEs GOMES FILHO defendem a admissão dos elementos obtidos, "desde que ligados ao fato que está sendo investigado". 227

De fato, grande parte da doutrina, cogitando da hipótese de obtenção de prova de crime diverso, insiste no reconhecimento da licitude de provas descobertas fortuitamente se o fato objeto de encontro fortuito é conexo com o fato investigado que ensejou, originariamente, a quebra do sigilo ou afastou a inviolabilidade domiciliar.

Para LÓPEZ-FrAGOSO, o que importa é “determinar el grado de conexión que deba presentarse entre el hecho delictivo descubierto casualmente (...) y el hecho penal objeto

\footnotetext{
${ }^{223}$ Processo Penal Constitucional... op.cit., p.98.

${ }^{224}$ As interceptações... op.cit., p.124.

225 Ibid., p.125-126. O autor continua: “Afora isso, deverão a polícia e o Ministério Público proceder a colheita de provas que possam sustentar um processo que não se baseie, apenas, na prova advinda da 'escuta'(...)". (p.126).

${ }^{226} \mathrm{O}$ encontro fortuito... op.cit., p. 14.

227 As nulidades... op.cit., p.176.
} 
del proceso en que se obtiene dicho descubrimiento y los sujetos" ${ }^{228}$, admitindo o autor o conhecimento fortuito

(...) imputable al mismo sujeto pasivo de la medida de intervención telefónica cuando concierna a un hecho delictivo conexo con el investigado $\mathrm{y}$, por el contrario, no sería utilizable un descubrimiento causal relativo a una infracción delictiva distinta a la investigada e imputable a un tercero. ${ }^{229}$

Nesse contexto, é que JUAN TAPIA propõe como solução, em definitivo, que "si los hallazgos casuales permiten inferir la existencia de un nuevo delito conexo al hecho investigado e imputable al sujeto pasivo de la diligencia, no existe impedimento alguno en su posterior valoración". 230

De fato, este critério da conexão consiste na confrontação entre o delito descoberto casualmente e aquele que fundamentou o pedido e legitimou a providência restritiva - no âmbito da qual se obteve o conhecimento fortuito -, e ainda, na sua relação com o sujeito passivo investigado, "ambos elementos contemplados según el fundamento de la medida que en su ejecución permitió adquirir casualmente el descubrimiento",231.

Para concretizar tal critério, muitos autores recorrem às regras de conexão previstas na legislação processual penal, já que "esse limite (crime conexo) deve ser definido, para não incidir no perigo da abertura conceitual que conduz à criação de espaços impróprios de discricionariedade judicial". ${ }^{232}$

Na doutrina nacional, merece destaque a opinião de ViCENTE GRECO FILHO e de LUIZ Flavio Gomes, que admitem a descoberta fortuita de novos fatos delituosos como prova nos casos de conexão, com a restrição de que o novo fato delituoso, igualmente, admita a medida da interceptação telefônica (isto é, seja punido com reclusão). Aliás, como lembra LuIZ Flavio GoMES, “em virtude das peculiaridades de nosso direito, urge falar-se

\footnotetext{
${ }^{228}$ Los descubrimientos casuales en las intervenciones telefónicas como medidas coercitivas en el proceso penal. In: Derechos y Libertades: Revista del Instituto Bartolomé de Las Casas. Madrid, nº 02, p.81-89, out/93 a mar/94. p.85.

${ }^{229}$ Ibid., p.87.

${ }^{230}$ Descubrimientos accidentales... op.cit., p.682-683.

${ }^{231}$ LÓPEZ FRAGOSO, Los descubrimientos casuales ... op.cit., p.85

${ }^{232}$ LOPES JUNIOR, Direito Processual Penal... op.cit. p.575 (em nota de rodapé).
} 
em conexão ou continência" ${ }^{\text {233 }}$, já que o Código de Processo Penal brasileiro faz essa distinção.

Para Vicente GReCo FILHO, na hipótese de surgir fato criminoso diferente daquele que fundamentou a interceptação, a gravação feita pode ser utilizada como prova do novo fato descoberto, "desde que a infração possa ser ensejadora de interceptação, ou seja, não se encontre entre as proibições do art. $2^{\circ}$ e desde que seja fato relacionado com o primeiro, ensejando concurso de crimes, continência ou conexão". ${ }^{234} \mathrm{O}$ autor justifica:

O que é objeto da investigação é um fato naturalísitico que pode apresentar várias facetas e ramificações. Não se investiga a classificação do delito, nem se pode exigir que se tenha conhecimento de todos os aspectos que envolve (aliás, se fossem conhecidos todos eles não precisaria ser realizada a interceptação). Assim, parece irrecusável a possibilidade de, por exemplo, na investigação de um homicídio, chegarse à ocultação de cadáver.

O que não se admite (inclusive o mesmo ocorre no direito estrangeiro) é a utilização da interceptação em face de fato em conhecimento fortuito e desvinculado do fato que originou a providência.

É certo que, no momento em que a interceptação foi autorizada, não se tinha o requisito dos indícios razoáveis da autoria da infração conexa ou em concurso, mas a interceptação incide sobre as pessoas, é uma exceção ao resguardo da intimidade, de modo que, uma vez legitimamente autorizada em face de alguém em virtude de fato criminoso, admite sua utilização em outros delitos (punidos com reclusão) relacionados com o primeiro. É fato notório que a atividade criminosa, especialmente a organizada, não se limita a uma especialidade, ramificando-se do tráfico de entorpecentes para o sequestro, o contrabando de armas, etc. E seria uma limitação excessiva não se permitir que, uma vez autorizada legitimamente a interceptação, não pudesse ela abranger toda a atividade criminosa dos interceptados no âmbito da continência ou conexão a partir do fato que a justificou. Toda investigação, como o próprio nome diz, envolve um certo grau de incerteza e de abrangência, incompatível com uma delimitação rigorosa de pessoas e fatos. ${ }^{235}$

LUIZ FlÁvio Gomes também adota o critério da conexão e continência. Assim, considera válida a prova se descoberto fato delitivo conexo com o investigado, mas desde que de responsabilidade do mesmo sujeito passivo e de que se trate de infração para a qual

\footnotetext{
${ }^{233}$ Interceptação telefônica e encontro fortuito de outros fatos. In: Boletim IBCCRIM. São Paulo, n 51 , p. 06, fevereiro/1997.

${ }^{234}$ Interceptação telefônica... op.cit., p.36. O autor, além da conexão e continência, inclui o concurso de crimes no critério de admissibilidade dos conhecimentos fortuitos. LUIZ FLAVIO GOMES critica essa posição, mencionando que o critério da conexão ou continência é, por si, só adequado para a solução do problema. (Interceptação telefônica: Lei 9.296/96 ... op.cit.,p.195).

${ }^{235}$ Interceptação telefônica... op.cit., p.36-38.
} 
se admita interceptação (art. $2^{\circ}$, inc. III). Por conclusão, o autor tem que: “(...) não vale a interceptação telefônica como meio probatório: a) seja em relação ao encontro de fato não conexo; b) seja quanto a fatos cometidos por terceiras pessoas, sem nenhuma relação de continência com o investigado", motivo pelo qual esse encontro fortuito valerá apenas como uma legítima notitia criminis para desenvolvimento de nova investigação independente. $^{236}$

Percebe-se que ambos os autores distinguem os conhecimentos fortuitos entre aqueles que contêm ou não uma conexão com o delito investigado, defendendo que, na primeira hipótese, o resultado probatório da interceptação vale como prova do fato novo descoberto fortuitamente, inclusive contra terceiros se houver relação de continência, de modo que a medida os revele como partícipes ou coautores do crime. ${ }^{237}$

Segundo Antonio SAntoro e Rodolfo SAntos, uma vez que se exige que a “autorização judicial decorra de fundados indícios de autoria ou participação em fato criminoso determinado, (...) só é possível emprestar validade probatória aos conhecimentos fortuitos advindos de escuta telefônica se o fato descoberto for conexo com o fato investigado, guardando, desta forma, um liame entre eles". ${ }^{238}$

\footnotetext{
${ }^{236}$ Interceptação telefônica e encontro fortuito de outros fatos... op.cit., p.6. Em outro texto sobre o assunto, o autor utiliza a expressão serendipidade para tratar do encontro fortuito, e explica: “(...) essa estranha palavra (...) significa algo como sair em busca de uma coisa e descobrir outra (ou outras), às vezes até mais interessante e valiosa. Vem do inglês serendipity (de acordo com o Dicionário Houaiss), onde tem o sentido de descobrir coisas por acaso." (Natureza jurídica da serendipidade nas interceptações telefônicas. Publicado em 21 de março de 2009. Disponível em: <http://www.lfg.com.br/public html/article.php?story=20090316100443595\&mode=print $>$. Acesso em: 04/011/2009).

${ }^{237}$ LUIZ FLÁVIO GOMES chega a sugerir que se fale em encontro fortuito de primeiro grau quando a prova descoberta se dá com relação a fatos conexos, ou quando haja continência, podendo a mesma conduzir a uma condenação penal, e inversamente, em encontro fortuito de segundo grau quando se tratem de fatos não conexos e sem relação de continência com o delito investigado, e nesse caso a prova produzida não poderá ser valorada pelo juiz. (Natureza jurídica da serendipidade... op.cit..)

${ }^{238}$ A validade dos conhecimentos fortuitos obtidos nas interceptações telefônicas. In: Boletim IBCCrim. São Paulo, no 210, p.15-16, maio/2010. p.16.

GERALDO PRADO não concorda com o critério da conexão, defendendo opinião diversa no sentido de que o encontro fortuito consiste em possibilidade concreta de toda iniciativa dirigida à aquisição de informações, considerando apenas duas ressalvas no caso das interceptações telefônicas: "a prova derivada do encontro fortuito será válida se relativa a crimes punidos com reclusão cuja ação penal seja pública incondicionada, independentemente de conexão ou continência." (Limite às interceptações (2006)... op.cit., p.63). PAULO RANGEL sugere a aplicação das regras de conexão entre o fato descoberto através da interceptação telefônica e o fato investigado, mas tão somente para fins de validar o conhecimento fortuito de crime punido com detenção, pois para o autor, como já destacado no ITEM 6.1, se a interceptação foi realizada nos estritos limites da lei, o conhecimento fortuito de outros fatos dela advindos significa lícita obtenção de prova. (Breves considerações... op.cit., p.147).
} 
E, de fato, a conexão "pressupõe um laço ou liame que estabelece a ligação entre as infrações praticadas e as pessoas nelas envolvidas" ${ }^{239}$, e no sistema processual penal brasileiro esta ligação pode ser de três ordens, conforme as regras de conexão ditadas pelo artigo $76^{240}$ do Código de Processo Penal: intersubjetiva, objetiva ou instrumental.

A conexão intersubjetiva, marcada pela pluralidade de agentes, quando por simultaneidade, exige unidade temporal, ou seja, duas ou mais infrações praticadas ao mesmo tempo, por várias pessoas reunidas (art.76, inc.I, primeira parte, CPP), quando por concurso, pressupõe infrações cometidas mediante ajuste prévio de agentes, embora diverso o tempo e o lugar (art.76, inc.I, segunda parte, CPP), e quando por reciprocidade implica que várias infrações foram praticadas por várias pessoas, umas contra as outras (art.76, inc.I, terceira parte, CPP).

AURY LOPES JUNIOR bem destaca que, nessa espécie, a única conexão que pode interessar é a intersubjetiva concursal (segunda modalidade do inciso I), na qual há concurso de agentes para a prática de dois ou mais crimes, de modo que além de se reunir os crimes, também há reunião dos agentes para simultaneidade de processo e julgamento: "logo, a busca e apreensão da casa de um dos corréus, pode gerar material probatório em relação a todos, reunidos por força do concurso de agentes". ${ }^{241}$

Mas, se, no mesmo caso, as infrações tiverem sido praticadas para facilitar ou ocultar outras, ou para conseguir impunidade ou vantagem em relação a qualquer delas, fala-se em então em conexão objetiva (art.76, inc.II, CPP). Por fim, tem-se hipótese de conexão instrumental (ou probatória) quando a prova de uma infração influir na prova de outra infração (art.76, inc.III, CPP).

Ora, considerando-se que a conexão implica reunião das infrações penais para fins de unidade de processo e julgamento $(\operatorname{art} .79, \mathrm{CPP})^{242}$, a prova obtida será admitida e

\footnotetext{
${ }^{239}$ MARQUES, José Frederico. Elementos de Direito Processual Penal. v. I. Campinas: Bookseller, 1997. p. 255.

240 “Art. 76. A competência será determinada pela conexão:

I - se, ocorrendo duas ou mais infrações, houverem sido praticadas, ao mesmo tempo, por várias pessoas reunidas, ou por várias pessoas em concurso, embora diverso o tempo e o lugar, ou por várias pessoas, umas contra as outras;

II - se, no mesmo caso, houverem sido umas praticadas para facilitar ou ocultar as outras, ou para conseguir impunidade ou vantagem em relação a qualquer delas;

III - quando a prova de uma infração ou de qualquer de suas circunstâncias elementares influir na prova de outra infração."

${ }^{241}$ Direito Processual Penal... op.cit.,p.580.

242 “Art. 79. A conexão e a continência importarão unidade de processo e julgamento (...)."

Segundo TOURINHO FILHO, “a conexão existe quando duas ou mais infrações estiverem entrelaçadas por um vínculo, um nexo, um liame que aconselha a junção dos processos, propiciando, assim, ao julgador perfeita
} 
passará a integrar o mesmo processo, composto por dois crimes conexos, ainda que a medida restritiva tenha sido determinada para apurar apenas um dos crimes.

Do mesmo modo, quando duas ou mais pessoas (pluralidade de agentes) forem acusadas pelo mesmo crime (unidade de infração), haverá reunião do caso penal por força da continência por cumulação subjetiva (art.77, inc.I CPP) ${ }^{243}$, de modo que o material probatório integrará o processo e todos responderão ao mesmo processo, acusados pelo mesmo delito. Essa espécie de continência, chamada por cumulação subjetiva, se verifica na hipótese de concurso de pessoas (coautoria e participação).

Portanto, "também a continência permite o desvio causal, pois a prova obtida de um dos réus passará a integrar o processo no qual também figura $(\mathrm{m}) \mathrm{o}(\mathrm{s})$ corréu(s)" ${ }^{244}$ Observe-se que, no caso da continência por cumulação subjetiva (assim como na conexão intersubjetiva concursal), o corréu não é terceiro, mas sim parte no processo.

Já a continência por cumulação objetiva se dá quando uma única conduta delituosa gera pluralidade de eventos típicos (art.77, inc.II CPP) ${ }^{245}$, ou seja, nas hipóteses de concurso formal.

Acredita-se que o critério da conexão e continência perfila-se como uma solução razoável ao tratamento dos conhecimentos fortuitos, mas a crítica que se faz a esse critério está no tratamento processual diferenciado a ser imposto a uma mesma figura - a dos conhecimentos fortuitos -, de modo que, os elementos de prova obtidos através de uma medida excepcional poderão ingressar no processo quando o conhecimento obtido fortuitamente revelar crime que contém uma relação de conexão ou continência com o crime objeto da investigação, mas não quando revelar fato totalmente independente do delito investigado.

Por esse motivo, prefere-se adotar o critério que diferencia os conhecimentos fortuitos dos conhecimentos da investigação, partindo-se dessa classificação a ser dada aos fatos obtidos casualmente durante a execução de um meio de obtenção de prova para se decidir pela sua (in)admissibilidade no processo.

visão do quadro probatório e, de consequência, melhor conhecimento dos fatos, de todos os fatos, de molde a poder entregar a prestação jurisdicional com firmeza e justiça”. (Processo Penal. v.2. 18.ed. São Paulo: Saraiva, 1997. p.184).

243 “Art. 77 - A competência será determinada pela continência quando: I - duas ou mais pessoas forem acusadas pela mesma infração."

${ }^{244}$ LOPES JUNIOR, Direito Processual Penal... op.cit., p.580.

245 “Art. 77 - A competência será determinada pela continência quando: (...) II - no caso de infração cometida nas condições previstas nos arts. 51, $\S 1^{\circ}, 53$, segunda parte, e 54 do Código Penal”. (A referência do inciso II é feita a dispositivos originais do Código Penal, substituídos pelos artigos 70, 73 e 74 na nova Parte Geral). 


\subsubsection{A fronteira entre conhecimentos fortuitos e conhecimentos da investigação}

Parte-se então do pressuposto de que os conhecimentos da investigação configuram uma categoria processual distinta dos conhecimentos fortuitos, a exigir tratamento processual distinto. Operada essa cisão, consoante a classificação dada aos fatos obtidos, dependerá o tratamento processual a dispensar quanto à admissibilidade da prova obtida e sua valoração.

Nesse momento, já está clara a premissa de que a problemática se dá sobre os fatos recolhidos por meio da realização legal de um meio de obtenção de prova autorizado judicialmente para a investigação de outro crime, ou seja, delimita-se o tema à obtenção de prova de crime diverso no curso de um procedimento lícito, sob a regência do princípio da especialidade, que justifica que a limitação a direitos fundamentais esteja restrita e vinculada à apuração do crime que ensejou a decisão judicial.

Mas a descoberta de fatos criminosos diversos dos indicados pelo juiz na decisão que autorizou uma medida restritiva decorre da imprevisibilidade inerente a todas as investigações criminais, e a fronteira que se pretende então delimitar está entre os fatos imputados à própria investigação, ou seja, que integram o processo histórico que, a seu tempo, ofereceu o motivo para uma ordem legítima, e aqueles que, inversamente, se levam em conta de conhecimentos fortuitos.

Concorda-se dessa maneira com o autor português FRANCISCO AGUILAR quando propõe que os conhecimentos fortuitos sejam entendidos em caráter residual face aos conhecimentos da investigação, sendo estes os fatos obtidos através da realização legal de um meio de obtenção de prova que se reportam ou ao crime que estava sendo investigado pela mencionada via ou a um outro delito que esteja baseado na mesma situação histórica de vida daquele. Assim, entre o crime que fundamentou o recurso ao meio de obtenção de prova em curso e o fato criminoso descoberto, "terá de haver uma identidade de investigação no sentido processual". ${ }^{246}$

De modo que os elementos recolhidos por um meio de obtenção de prova, voltados a uma determinada investigação, podem ser usados como prova bastante de outros fatos encontrados (prova idônea à valoração judicial), desde que apresentem estreita referência com o delito que justificou a providência restritiva.

${ }^{246}$ Dos conhecimentos fortuitos... op.cit., p.17-18. 
Em contrapartida, os conhecimentos que não apresentem esta identidade investigatória com o crime legitimador da medida restritiva, hão de ser tidos como fortuitos, a requerer um tratamento distinto. E, sobretudo por força dessa diferença, a necessidade de um critério objetivo, com assento legal, que concretize essa demarcação de fronteiras entre os institutos, é manifesta.

Com efeito, como adverte, com razão, FrAnCISCO AguILAR, para delimitar o conceito de conhecimentos da investigação não basta um consenso doutrinal ou jurisprudencial, sendo necessário socorrer-se de um critério objetivo ou legal que concretize essa ideia de unidade de investigação processual, para se evitar que em situações limite e ad terrorem, se esvazie de tal maneira o conceito de conhecimentos fortuitos que deixe de fazer sentido qualquer referência à diferença entre estes dois institutos processuais. ${ }^{247}$

Nesse contexto, as normas positivas suscetíveis de preencher esse conceito que distancia conhecimentos fortuitos dos conhecimentos da investigação, a exemplo do pensado por esse autor no ordenamento português ${ }^{248}$, são aquelas insculpidas nos artigos 76 e 77 do Código de Processo Penal brasileiro, que ditam as regras de conexão e continência no ordenamento nacional, de modo que tais hipóteses não restam abrangidas em outro universo senão o dos conhecimentos da investigação, e como tais, sequer serão considerados encontros fortuitos.

Observa-se assim, que o critério exposto no tópico anterior e esse que ora se adota como melhor solução não se excluem, pelo contrário, se complementam, mas tão somente na medida em que aquele primeiro vai delimitar a fronteira conceitual daquilo que se passará a chamar de conhecimentos fortuitos.

Só que a atenção deve estar voltada para o fato de que a relativização do princípio da especialidade da prova exige sempre uma leitura restritiva das regras de conexão, bem como a demonstração da real existência dos elementos que a compõem, pois “o que não se

\footnotetext{
${ }^{247}$ Ibid., p.20.

${ }^{248}$ Ao se referir ao artigo 24, $\mathrm{n}^{\mathrm{o}} 1$ do Código de Processo Penal português, o FRANCISCO AGUILAR propõe que “(...) uma aproximação ao conceito de 'unidade de investigação processual' ou de 'uma mesma situação histórica de vida' só é susceptível de ser configurada no $\mathrm{n}^{\circ} 1$ do artigo $24^{\circ}$ do C.P.P; isto é, os critérios objectivos vertidos neste preceito legal com o fim de determinar a conexão de processos consubstanciam crivos válidos no sentido de tornar operativo o referido conceito de 'unidade processual'(...)". (Ibid., p.21).
} 
pode tolerar é a fraude de etiquetas, em que a conexão é engendrada para permitir o desvio da vinculação causal imposta pelo princípio da especialidade”. ${ }^{249}$

Destarte, aproveitando-se das regras de conexão e continência, a limitação que se propõe está embasada no sentido de que apenas os conhecimentos da investigação surtirão efeitos probatórios, já que os elementos de prova recolhidos integrarão o mesmo processo no âmbito do qual foi autorizada a medida de interceptação telefônica ou de busca e apreensão. Lembre-se que a excepcionalidade e lesividade de tais medidas exigem uma vinculação àquele processo: "Trata-se de uma vinculação causal, em que a autorização judicial para a obtenção da prova naturalmente vincula a utilização naquele processo (e em relação àquele caso penal), sendo assim, ao mesmo tempo, vinculada e vinculante". ${ }^{250}$

Mas, se os fatos ocasionalmente conhecidos não tiverem conexão/continência com o crime para o qual a autorização foi dada, estes conhecimentos, ditos então fortuitos, não poderão, portanto, ingressar nos autos, e não poderão servir em processo distinto como prova para a deflagração de ação penal ou ser valorados para a condenação pelo crime descoberto. Entretanto, isso não significa que essa descoberta deva ser inquinada, de plano, como ilícita.

\subsubsection{Valor dos conhecimentos fortuitos em decorrência do critério adotado}

Sendo a proibição acima destacada apenas probatória, não se nega a possibilidade de que os conhecimentos obtidos a partir do desvio causal, fora do limite dos conhecimentos da investigação, sejam conformadores de um indício, servindo como "starter da investigação do novo crime"251, sendo assim, notícia de crime para o início de nova investigação, no âmbito da qual novas medidas restritivas eventualmente poderão ser autorizadas (sempre com exigência de prévia autorização judicial motivada, pautada pelo princípio da proporcionalidade), e esse é o critério que se adota para o alcance dos conhecimentos fortuitos.

\footnotetext{
${ }^{249}$ LOPES JUNIOR, Direito Processual Penal... op.cit., p.581. A preocupação do autor vem manifestada após constatar a "abertura do conceito de 'conexão' na sistemática do CPP e aos eventuais abusos a que pode - essa abertura - dar azo". (p.580)

${ }^{250}$ Ibid., p.574.

${ }^{251}$ Ibid., p.578.
} 
Recorre-se à distinção feita por LÓPEZ-FRAGOSO entre os efeitos investigatórios e os efeitos probatórios que uma medida excepcional pode gerar para esquematizar uma solução para a problemática, pois aqueles que se passou a chamar de conhecimentos fortuitos limitar-se-ão a surtir efeitos investigatórios, ou seja, "los posibles efectos que puedan producir estos hallazgos fortuitos como adquisición de una notitia criminis, la cual podrá dar lugar al inicio de una instrucción independiente para averiguar y comprobar el conocimiento casualmente obtenido". ${ }^{252}$

Significa que as informações obtidas em relação ao conhecimento fortuito não servem para a demonstração desse delito. Não podem servir, portanto, como prova em processo distinto, pois somente podem dar lugar ao início de novas investigações, dentro das quais, se tiver uma gravidade penal aparentemente suficiente para tolerar proporcionalmente sua adoção, se poderá autorizar, dentro dos limites legais, novas medidas excepcionais destinadas a investigar e recolher novos elementos de prova.

Assim, os conhecimentos fortuitos valerão como meras notícias de crime ${ }^{253}$ para dar início às correspondentes investigações que venham eventualmente a comprovar o conhecimento casualmente obtido, "mas a prova desse crime deve ser construída de forma autônoma" ${ }^{254}$. À evidência, não se prestam a embasar uma denúncia ou a formação do convencimento do juiz.

LENIO STRECK, valorando o encontro fortuito como um elemento indiciário para o início da investigação do crime descoberto, assevera:

Não pode o Estado ignorar esse fato (a existência de um crime). (...) Isto seria um simulacro! Como dito a informação/descoberta do crime, em tais circunstâncias, deverá servir de indício para a busca da comprovação da existência do crime. Nunca tal informação poderá ser usada como prova bastante até mesmo para a instauração da ação penal. Exige-se, enfim, a prova da prova! $!^{255}$

\footnotetext{
${ }^{252}$ Los descubrimientos casuales... op.cit., p.88. Muito embora o autor espanhol não trace a distinção entre conhecimentos fortuitos e conhecimentos da investigação, adotando o critério da conexão.

${ }^{253}$ TORQUATO AVOLIO concorda com a utilização do critério da conexão e da continência, mas manifesta sua restrição quanto à utilização do material que destoa do objeto da investigação como notícia de crime: "A menos que a notícia-crime servisse para a prisão em flagrante da pessoa que estivesse praticando crime permanente, como o de sequestro, ou para medida de caráter urgente, como a desativação de uma bomba ou o impedimento da consecução de um crime grave, o que seria admissível com base no critério da proporcionalidade. O direito à prova, por si só, não é suficiente para legitimar a notícia-crine obtida dessa forma, carecendo de justa causa eventual inquérito policial instaurado com base nela." (Provas ilícitas... op.cit., p.231).

${ }^{254}$ LOPES JUNIOR, Direito Processual Penal... op.cit.,p.579

${ }^{255}$ As interceptações... op.cit., p.129-130
} 
De fato, quando se fala em conhecimentos fortuitos, não significa que a descoberta não tem nenhum valor: a partir dela pode-se desenvolver nova investigação, independente, funcionando como uma notitia criminis. Afora isso, deverão os agentes da persecução penal proceder à colheita de elementos de prova que possam sustentar um outro processo, que não esteja baseado, apenas, no material advindo do meio de obtenção de prova autorizado. Nas palavras de FrANCISCO AGUILAR: "Os conhecimentos obtidos através de interceptação, por 'sorte', somente podem ser utilizados como 'pistas' para investigação de outro fato, não servindo como prova de sua concretização; podem servir como indício, mas não se sustenta, eventual condenação, neste tipo de prova". ${ }^{256}$

${ }^{256}$ Dos conhecimentos fortuitos... op.cit., p. 36. 


\section{BREVE CASUÍSTICA DOS CONHECIMENTOS FORTUITOS}

A proposta do presente estudo chega ao seu termo, mas com algumas questões específicas a serem enfrentadas.

\subsection{Conhecimento fortuito de crime permanente: a situação de flagrância nas buscas e apreensões}

Ainda que alguns considerem que o principio da especialidade é exigido com menos intensidade nas buscas do que nas interceptações, e não se ignore que a interceptação se prolonga no tempo, enquanto a busca se dá em unidade de ato, o que importa é que ambos restringem por ordem judicial o direito constitucional da intimidade.

A busca possui sim uma especialidade, ou seja, deve objetivar que a prova, obtida através desse meio de pesquisa, se destine à comprovação do delito que está sendo investigado, sob pena de se admitir que a simples emissão de um mandado judicial autorizaria uma ampla devassa no interior da residência, permitindo a apreensão de tudo que fosse encontrado.

Daí porque, no caso de cumprimento de uma ordem judicial de busca domiciliária, a autorização para entrada em casa ${ }^{257}$ alheia deve ser a mais determinada possível quanto à finalidade, objeto e sujeito contra quem é procedida a diligência.

A questão do encontro fortuito nas buscas foi colocada sob a perspectiva da licitude ou não da apreensão, em domicílio, de objeto ou documento que não esteja previamente especificado no mandado judicial, de modo que apenas aqueles conhecimentos considerados da investigação servirão como elemento de prova para a demonstração do delito casualmente descoberto.

Mas nesse ponto, já se imagina que não se pode confundir o critério ora defendido com as situações em que os agentes, durante a busca domiciliar se deparam com um crime

\footnotetext{
${ }^{257}$ Aqui compreendida no sentido amplo de casa protegida constitucionalmente, expressão que abrange não apenas a residência ou domicílio de uma pessoa, mas também outros locais dotados de intimidade espacial, cf. nota de rodapé $n^{\circ} 89$.
} 
permanente, posto que a apreensão, nas situações de flagrância $(\operatorname{art.303~CPP})^{258}$, dispensa autorização judicial, devendo a autoridade policial, logo que tiver conhecimento da infração, apreender os objetos que tiverem relação com o fato $\left(\operatorname{art.} 6^{\circ}, \text { II CPP }\right)^{259}$.

Assim, se durante o cumprimento de um mandado de busca domiciliar visando à apreensão de documentos para apuração de um delito de sonegação fiscal forem encontradas armas de fogo e munições ${ }^{260}$ no local, ainda que sem qualquer relação com o crime investigado (conhecimentos fortuitos), lícita será a apreensão destes objetos, pois constituem o próprio corpo de delito do crime descoberto, e servirão como prova dessa infração penal, porque para esse fim não seria necessário autorização judicial para a invasão do domicílio, inexistindo óbice para a apreensão dos objetos, embora não detalhados no mandado.

Segundo FABIO MOTTA LOPES, "caso os agentes estejam diante de um crime permanente (...) nessa hipótese, que caracteriza a situação de flagrância (art. 5º XI, da CF e art. 303 do CPP), o próprio mandado de busca e apreensão se torna dispensável". ${ }^{261}$ Por isso, de acordo com o Superior Tribunal de Justiça, não se pode desprezar, ainda que não especificados no mandado de busca e apreensão, "objetos que, flagrantemente, são utilizados para o cometimento de outros crimes”, de modo que “(...) a apreensão de coisas que, sem maiores exercícios, são utilizadas para a prática de crimes, é plenamente admissível". ${ }^{262}$

De fato, em sua maioria, doutrina e jurisprudência admitem a apreensão de objetos relativos a outro crime, mas desde que se trate de delito permanente, situação que caracteriza a flagrância e representa exceção à inviolabilidade do domicílio.

\footnotetext{
${ }^{258}$ Nos termos do art. 303 do Código de Processo Penal: "Nas infrações permanentes, entende-se o agente em flagrante delito enquanto não cessar a permanência".

259 "Art. 6․․ Logo que tiver conhecimento da prática da infração penal, a autoridade policial deverá: (...) II apreender os objetos que tiverem relação com o fato, após liberados pelos peritos criminais."

${ }^{260}$ Como o crime previsto no artigo 12 da Lei no 10.826/2003 (Estatuto do Desarmamento) é classificado sob a categoria de permanente, ocorre flagrante delito. E de acordo com o art. 303 do CPP, o estado de flagrância nesse tipo de crime persiste enquanto não cessada a permanência.

Posse irregular de arma de fogo de uso permitido: "Art. 12. Possuir ou manter sob sua guarda arma de fogo, acessório ou munição, de uso permitido, em desacordo com determinação legal ou regulamentar, no interior de sua residência ou dependência desta, ou, ainda no seu local de trabalho, desde que seja o titular ou o responsável legal do estabelecimento ou empresa. Pena - detenção, de 1 (um) a 3 (três) anos, e multa."

${ }^{261} \mathrm{O}$ encontro fortuito... op.cit., p. 14.

${ }^{262}$ Habeas Corpus 151.530/PB... cit.
} 
Mesmo que a regra constitucional que assegura a inviolabilidade do domicílio, de forma expressa, faça a ressalva $\left(\operatorname{art} .5^{\circ}, \mathrm{XI} \mathrm{CF}\right)^{263}$, de modo que ocorrendo flagrante a apreensão dispensa autorização judicial, "tal permissão não significa, porém, que se possa apreender toda e qualquer coisa, sem qualquer relação com o fato investigado". ${ }^{264}$

Assim, para se considerar que inexiste óbice para a apreensão dos objetos que não foram detalhados no mandado quando o que é encontrado pelo agente policial se trata de flagrante delito de outro crime (motivo pelo qual aqui não há a exigência de conexão entre o delito investigado e o descoberto), é necessário visitar uma teoria desenvolvida pela jurisprudência norte-americana e que se acredita compatível com o sistema processual penal brasileiro no que toca ao tema.

Trata-se da plain view doctrine, que segundo ensina WALTER NUNES DA SILVA JUNIOR, cuida-se de

(...) uma forma de tornar, com base no princípio da razoabilidade, legítima a apreensão de elementos probatórios do fato investigado ou mesmo de outro crime, quando, a despeito de não se tratar da finalidade gizada no mandado de busca e apreensão, no momento da realização da diligência, o objeto ou documento é encontrado por se encontrar à plena vista do agente policial. ${ }^{265}$

É que, ainda que diversos os motivos e fins da diligência a que se destina o mandado judicial de busca, consoante a teoria, estando o objeto exposto à plena vista, não há busca, e inexiste expectativa de privacidade.

Embora inicialmente formulada antes disso, foi com o julgamento do caso Arizona vs. Hicks (1986) que ela se aperfeiçoou para exigir probable cause de que o objeto encontrado à plena vista esteja relacionado a um delito para que seja apreendido. Reportase especificamente àquelas diligências de busca realizadas em local protegido por cláusula constitucional que tutela a inviolabilidade domiciliar e distingue-se, assim, o problema de

\footnotetext{
${ }^{263}$ Nos termos do art.5 $5^{\circ}$ XI, da CF, “a casa é asilo inviolável do indivíduo, ninguém nela podendo penetrar sem consentimento do morador, salvo em caso de flagrante delito ou desastre, ou para prestar socorro, ou, durante o dia, por determinação judicial."

${ }^{264}$ PITOMBO, Da busca e da apreensão... op.cit., p.266.

265 Curso de Direito Processual Penal: teoria (constitucional) do processo penal. Rio de Janeiro: Renovar, 2008. p.523-524.
} 
ver um objeto suspeito não incluído na ordem de busca do ato de apreendê-lo, pois para este último "exige que se acredite causa probable de su vinculación con un delito". ${ }^{266}$

Desse modo, conforme a teoria, desenvolvida pela Corte Suprema dos Estados Unidos no âmbito das buscas e apreensões, "resultan legitimados aquellos secuestros practicados sin la orden correspondiente, cuando los elementos se encontraren a plena vista, de modo que el personal policial se tropiece con ellos y existan causas razonables para su incautación". ${ }^{267}$

Contudo, para que tal postura seja coerente com o que se vem propondo, deve-se ter em mente como válida não só a exigência de que o objeto encontrado esteja relacionado a um delito para que seja apreendido (tal como a posse ilegal de arma de, no exemplo acima), mas, principalmente, que a descoberta fortuita se dê durante a realização legítima da diligência, com respeito aos limites traçados no mandado de busca, já que "eventual ilegalidade ocorrente na busca contagia, por completo, o apossamento dela originário". ${ }^{268}$

Aliás, segundo informações trazidas por SERGIO MORO sobre a plain view doctrine, em Horton vs. California (1990), a Suprema Corte norte-americana firmou o entendimento de que é válida a apreensão de item não descrito no mandado se: “a) o agente policial estiver validamente presente no local no qual o objeto se encontra; b) o objeto apreendido for visível de plano (daí a origem da denominação da doutrina); e c) o agente policial perceber de plano o caráter de prova ou ilícito do objeto, sem necessidade de intromissão maior". ${ }^{269}$

E de fato, de acordo com Hairabedián, citado por WALter Nunes DA SiLva JUNIOR:

(...) la jurisprudencia de la Corte Suprema de los Estados Unidos ha admitido la validez de las probanzas adquiridas durante un allanamiento, aunque los efectos no estén enumerados en la orden judicial respectiva, cuando en oportunidad de su ejecución el funcionario tropieza por accidente con pruebas de un delito, o donde las encuentra a simple vista, ya que en tal caso no necesita desviar la mirada e ignorar lo que evidentemente tiene frente a él. ${ }^{270}$

\footnotetext{
${ }^{266}$ CARBONE, Requisitos constitucionales ... op.cit., p.393.

267 TAPIA, Descubrimientos accidentales ... op.cit., p.677.

${ }^{268}$ PITOMBO, Da busca e da apreensão... op.cit., p.265.

${ }^{269}$ Crime de lavagem... op.cit., p. 123.

${ }^{270}$ Curso de Direito Processual Penal... op.cit., p.524.
} 
Por isso mesmo, conforme noticia WALTER NuneS DA SILVA JUNIOR, algumas importantes exceções começaram a ser registradas pela Corte quanto à aplicação da teoria em determinadas situações, das quais não se pode descuidar, mesmo no ordenamento pátrio. A primeira delas refere àquelas hipóteses em que o agente já cumpriu a diligência e a prova surge após a apreensão daquele objeto constante do mandado judicial, e a outra àqueles objetos encontrados após a revista de lugares nos quais o objeto do mandado jamais poderia se encontrar. ${ }^{271}$

Seguindo este caminho trilhado pela jurisprudência norte-americana, JUAN TAPIA inclui na categoria de medida ilegalmente executada

(...) aquellos supuestos en que pese a haberse encontrado aquello que se buscaba se siguió adelante con la diligencia a la caza de otros elementos; se revisan lugares donde claramente no va a encontrarse aquello que se Le indicó que buscara (por ej., se ordena el secuestro de un automotor y se busca en el cajón de un escritorio) o se requisan objetos desvinculados de los pretendidos y que a simple vista no presentan indicios de constituir ilícito alguno. ${ }^{272}$

Lembre-se que "a rigidez, na realização da busca, não se limita ao conteúdo da ordem, mas também quanto à maneira de realizá-la". 273

Assim, retomando o exemplo anterior, se as armas de fogo e as munições não estavam à plena vista dos agentes policiais, ou se estes já tinham executado o objeto do mandado (encontrando os documentos comprobatórios do delito fiscal) e continuaram revistando o local, vindo então a encontrar aqueles objetos, o conhecimento fortuito do delito envolvendo a posse ilegal não surtirá efeitos, já que ilícita foi a apreensão das armas de fogo e das munições em razão da ilegalidade do excesso cometido. Como conclui THIAGO ANDRÉ PIEROBOM DE ÁvILA:

(...) deve-se ressaltar que a descoberta desses objetos deve ser efetivamente fortuita, realizada no curso normal da busca do objeto inicial para o qual havia autorização judicial. Se há uma busca abusiva em locais não discriminados na autorização, ou se a busca prossegue mesmo após a apreensão do objeto para o qual havia autorização, sem

${ }^{271}$ Ibid., p.524.

${ }^{272}$ Descubrimientos accidentales... op.cit., p.676.

${ }^{273}$ PITOMBO, Da busca e da apreensão... op.cit., p.209. 
que haja qualquer legitimação de intervenção indiciaria para essa outra busca, a situação configura a ilicitude da prova. ${ }^{274}$

Imagine-se também a hipótese de uma busca autorizada para apreensão de computadores e de documentos comprobatórios do delito de sonegação fiscal objeto de investigação, e durante o cumprimento da medida os agentes policiais logram encontrar um cadáver após escavações no terreno da residência - local no qual o objeto do mandado jamais poderia se encontrar.

Nessas situações, há um excesso aos limites do mandado judicial, e os conhecimentos daí advindos configuram prova ilícita em razão de uma violação ilegal à privacidade de seu morador. É dizer: como consequência do procedimento irregular (abuso na busca domiciliar) exclui-se a informação, "la que no podrá ser utilizada siquiera como mera notitia criminis, ello en razón de verificarse en su origen una vulneración del derecho constitucional a la intimidad". ${ }^{275}$ Com efeito, não há que se admitir o abuso do poder de polícia no cumprimento de medidas judicialmente determinadas e limitadas, e aqui “(...) o ato de vasculhar todos os locais da casa e apreender objetos distintos dos contidos na autorização é um requisito para evitar eventuais arbitrariedades (a finalidade do principio da inadmissibilidade)". ${ }^{276}$

\subsection{Conhecimento fortuito de crime punido com detenção obtido em interceptação telefônica}

Retoma-se aqui a dúvida suscitada no ITEM 3.1.3.1, quando se indagou da possibilidade de uma informação surgida sobre um crime punido com detenção no decorrer de uma interceptação judicialmente autorizada, servir de prova dessa infração descoberta fortuitamente.

Ao lembrar que o legislador ordinário estabeleceu que só será admitida a interceptação de comunicações telefônicas se o fato investigado constituir infração penal

\footnotetext{
${ }^{274}$ Provas ilícitas e proporcionalidade... op.cit., p.226.

275 TAPIA, Descubrimientos accidentales ... op.cit., p.677.

${ }^{276}$ ÁVILA, Provas ilícitas e proporcionalidade... op.cit., p.227.
} 
punida com reclusão (art. $2^{\circ}$, inc. III, Lei 9.296/96), concorda-se com GERALDO PRADO quando afirma que

(...) partindo do pressuposto de que a Constituição da República pode instituir fontes autônomas de justificação para determinados comportamentos e não admitir a justificação de outros, por critérios que os constituintes julgaram razoáveis, o legislador ordinário cumpriu a sua missão reguladora e estabeleceu que as informações derivadas de interceptação só servem como prova de crimes punidos com reclusão. Assim, muito embora a informação sobre o crime punido com detenção exista (ou sobre a contravenção penal ou ainda acerca da infração penal de menor potencial ofensivo) e tenha sido obtida de modo ilícito, pois a interceptação estava autorizada por juiz criminal, esta informação não será válida como prova dessas infrações e não poderá servir de base para a condenação. ${ }^{277}$

Ora, de fato a interceptação não é admitida para a prova de infrações penais não punidas com reclusão, regime legal que corresponde a uma ponderação de interesses desejada pelo legislador, e ainda que não represente a melhor opção, esse é o limite. E quando se questiona se a informação obtida através desse meio de obtenção de prova pode servir de base para a deflagração de ação penal e ser valorada para uma condenação por crime punido com detenção, descoberto fortuitamente, há que se responder negativamente. Assim, ainda que realizada a interceptação telefônica de forma legal e legítima, a partir de decisão fundamentada, as informações fortuitas coletadas por essa via relativas à existência de um crime punido com detenção não serão válidas como prova dessa infração.

Faz-se, no entanto, uma ressalva, que é aquela relacionada aos conhecimentos imputados à própria investigação, ou seja, quando o crime punível com pena de detenção é conexo, ou guarda uma relação de continência, com o crime impulsionador da escuta, que implicará em unidade de processo e julgamento. Desse modo, apenas os conhecimentos da investigação, na delimitação adotada no capítulo anterior, surtirão efeitos probatórios com relação ao crime punido com detenção, “uma vez que não é razoável, ou é legalmente impossível em alguns casos, admitir a prova quanto ao delito inicialmente investigado e não admiti-la quanto ao outro, dado o vínculo legal (conexão) que os une”. 278

E esta parece ser a opinião do Supremo Tribunal Federal, que já considerou “compatível com o art. 5, XII e LVI, o uso de prova obtida fortuitamente através de

\footnotetext{
${ }^{277}$ Limite às interceptações (2006)... op.cit., p.60-61.

${ }^{278}$ SILVA, Cesar Dario Mariano da. Provas ilícitas... op.cit., p.40.
} 
interceptação telefônica licitamente conduzida, ainda que o crime descoberto, conexo ao que foi objeto da interceptação, seja punido com detenção", ${ }^{279}$

Pode-se assim concordar com a decisão do STF proferida no já mencionado HC 83.515: "Uma vez realizada a interceptação telefônica de forma fundamentada, legal e legítima, as informações e provas coletas dessa diligência podem subsidiar denúncia com base em crimes puníveis com pena de detenção, desde que conexos aos primeiros tipos penais que justificaram a interceptação". ${ }^{280}$ Inclusive como já o fez SERGIO MORO:

Se lei autoriza a interceptação telefônica apenas para investigação de crimes apenados com reclusão (art. $2^{\circ}$, III, da Lei $n^{\circ}$ 9.296/96), não pode o método ser utilizado, ainda que fortuitamente, para colher provas de crimes apenados com detenção. Haveria violação da restrição legal do emprego do método, que é baseado em juízo do legislador quanto à proporcionalidade entre a gravidade do crime e o grau de afetação da esfera privada pelo método. Mesmo nesse caso, há que ressalvar, na esteira do precedente do STF no HC 83.515/RS, a validade das provas se os crimes descobertos estiverem em conexão com delitos para os quais seria válido o emprego do método especial de investigação. ${ }^{281}$

Mesmo que o Pretório Excelso não faça a distinção entre o que se entende por conhecimentos fortuitos e por conhecimentos da investigação, certo é que, o que não se admite, é que o material colhido durante uma interceptação, legitimada para investigação de um crime apenado com reclusão, seja utilizado para instauração de outro processo criminal ou para iniciar investigação distinta, relativa à prática de um crime punido com detenção que não guarda aquela identidade de investigação com o crime que fundamentou o recurso ao meio de obtenção de prova em curso.

\footnotetext{
${ }^{279}$ Agravo Regimental em Agravo de Instrumento 626.214/MG...cit.

${ }^{280}$ Habeas Corpus $83.515 / R S$... cit.
}

$\mathrm{O}$ voto do Min. JOAQUIM BARBOSA é elucidativo sobre a questão submetida à debate: “A interceptação telefônica, no caso dos presentes autos, foi decretada para que se investigassem crime apenados com reclusão, tendo sido constatada incidentamente a ocorrência de outros delitos, estes punidos com detenção. A questão que se põe é se deveriam ser invalidadas, relativamente aos crimes cuja pena é a detenção, as provas resultantes das interceptações realizadas. O exame dessa questão também deve ser feito à luz do princípio da razoabilidade, juntamente com a análise do teor do inciso II do artigo $2^{\circ}$ da Lei 9.296/1996. (...) Ora, o escopo da Lei 9.296/1996 foi o de não invadir a privacidade do investigado, quando a gravidade do crime não justificasse tal medida excepcional. No caso em exame, não era possível, a princípio, ter certeza sobre a eventual descoberta de crimes apenas com detenção no decorrer das investigações, pois se tratava de suposta organização criminosa, cujas atividades eram várias. Assim, entendo que, embora não decretada para este fim específico, a interceptação serve como prova dos crimes punidos com detenção, em vista da licitude da medida, que terminou por revelar fortuitamente também os crimes cuja pena é a reclusão, conexos àqueles e seu verdadeiro escopo."

${ }^{281}$ Crime de lavagem... op.cit., p.129. 
Destaque-se que, nessa hipótese, as informações obtidas acerca do crime punido com detenção integram a figura dos conhecimentos fortuitos (segundo o conceito adotado no capítulo anterior), mas aqui, eles não surtirão sequer aqueles efeitos investigatórios, porque isso representaria uma burla ao artigo $2^{\circ}$, inciso III da Lei ${ }^{\circ}$ 9296/96.

\subsection{Conhecimento fortuito de crime de competência material de juízo diverso e conhecimento da participação no delito de alguém que detenha prerrogativa de foro em virtude de suas funções}

A Constituição Federal (art. $5^{\circ}$, inc. XII) já restringiu a interceptação telefônica ao âmbito criminal ("para fins de investigação criminal ou instrução processual penal"), mas “coube ao legislador ordinário avançar no percurso do estabelecimento da competência, traçando aquela de natureza funcional do juiz" ${ }^{282}$, quando prescreveu no artigo $1^{\circ}$ caput da Lei n 9.296/96, que a medida “dependerá de ordem do juiz competente da ação principal”.

Gustavo BADARÓ destaca que mesmo na fase do inquérito policial "deve se projetar qual será a 'Justiça Competente' para futura ação penal. Concluindo-se, por exemplo, pela competência da Justiça Federal, o pedido de interceptação deverá ser formulado perante um de seus órgãos". Do mesmo modo, "se a competência para processar a futura ação penal for de Tribunal, em razão de o investigado gozar de foro por prerrogativa de função, será o órgão de segundo grau ou o Tribunal Superior o competente para a decretação da interceptação telefônica". ${ }^{283}$

Com efeito, a garantia do juiz natural não se restringe ao direito de ser processado e julgado por órgão previamente conhecido, também se aplicando às hipóteses de restrição de direitos fundamentais no curso da investigação, notadamente as que pressupõem permissão judicial, como a busca e apreensão e a interceptação das comunicações telefônicas.

Mas ToRquato Avolio, ao mencionar que o dispositivo "quer enfatizar que a interceptação, particularmente, somente pode ser autorizada pelo juiz da causa”, destaca

\footnotetext{
${ }^{282}$ AVOLIO, Provas ilícitas... op.cit., p.217.
}

${ }^{283}$ Direito Processual Penal... op.cit., p.291. 
que essa regra deve "ser aplicada com temperamentos na fase investigatória". ${ }^{284}$ Com efeito, e conforme já registrado pelo STJ:

Prevalece na doutrina e na jurisprudência o entendimento segundo o qual a competência para autorizar a interceptação telefônica no curso das investigações deve ser analisada com cautela, pois pode ser que, inicialmente, o magistrado seja aparentemente competente e apenas no curso das investigações se verifique a sua incompetência. ${ }^{285}$

Assim, há que se analisar se a nova informação ou a descoberta da participação de terceiro, no curso da interceptação, altera a competência do juiz que autorizou a diligência.

Pode mesmo ocorrer que durante o monitoramento telefônico seja apurada uma circunstância que revele que o crime investigado é de competência de juiz diverso, como quando a autorização para a medida é dada por juiz estadual e é apurado crime de competência do juízo federal.

Retoma-se aqui a referência já feita no ITEM 5.2 ao HC $\mathbf{8 1 . 2 6 0}{ }^{286}$, em que se discutiu no STF a licitude da prova resultante de interceptação telefônica quando a autorização da medida se deu por juiz que posteriormente se declarou incompetente, uma vez que o delito descoberto não se compreendia na sua esfera de competência. Repita-se a transcrição do seguinte trecho do voto do Ministro SEPÚLVEDA PERTENCE:

(...) parece manifesto que seria um contra-senso sujeitar a licitude da prova casualmente captada a que o delito descoberto se compreendesse na competência do juiz que, com vistas à averiguação da suspeita de um outro - compreendido na sua esfera de jurisdição - houvesse autorizado legitimamente a interceptação.

A questão restou assim ementada, no ponto que interessa:

Interceptação telefônica: exigência de autorização do "juiz competente da ação principal" (L. 9296/96, art. 1º): inteligência. 1. Se se cuida de obter a

${ }^{284}$ Provas ilícitas... op.cit., p.218-219.

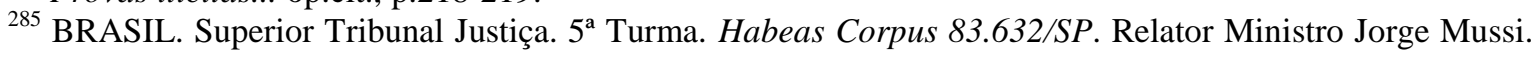
Julgado em 19/08/2010, DJe 20/09/2010. Acórdão disponível em: <https://ww2.stj.jus.br/revistaeletronica/Abre Documento.asp?sSeq=996036\&sReg=200701201332\&sData= 20100920\&formato=PDF>. Acesso em: 09/07/2011.

${ }^{286}$ Habeas Corpus 81.260/ES... cit. 
autorização para a interceptação telefônica no curso de processo penal, não suscita dúvidas a regra de competência do art. $1^{\circ}$ da L. 9296/96: só ao juiz da ação penal condenatória - e que dirige toda a instrução -, caberá deferir a medida cautelar incidente. 2. Quando, no entanto, a interceptação telefônica constituir medida cautelar preventiva, ainda no curso das investigações criminais, a mesma norma de competência há de ser entendida e aplicada com temperamentos, para não resultar em absurdos patentes: aí, o ponto de partida à determinação da competência para a ordem judicial de interceptação - não podendo ser o fato imputado, que só a denúncia, eventual e futura, precisará -, haverá de ser o fato suspeitado, objeto dos procedimentos investigatórios em curso. 3. Não induz à ilicitude da prova resultante da interceptação telefônica que a autorização provenha de Juiz Federal - aparentemente competente, à vista do objeto das investigações policiais em curso, ao tempo da decisão que, posteriormente, se haja declarado incompetente, à vista do andamento delas.

De fato, não se têm dúvidas quanto à competência quando a autorização para interceptação telefônica se dá no curso de um processo-crime, já que caberá ao juiz da ação penal o deferimento da medida excepcional.

Porém, durante a fase de investigação, os crimes objeto de apuração não estão ainda perfeitamente delineados, e conforme decidiu o STF no HC 99.619, embora cumpra “ao juiz do processo apreciar os requerimentos sujeitos à reserva judicial levando em consideração as expectativas probatórias da investigação", se posteriormente, à vista do andamento das diligências, "for constado que os crimes descobertos e provados são da competência de outro Juízo, não se confirmando a inicial expectativa probatória, o processo deve ser declinado (...)". ${ }^{287}$ No feito, discutiu-se a questão porque o Juiz de Direito, tendo presente a ocorrência de tráfico interno de drogas, atendeu à representação subscrita pela autoridade policial e autorizou a quebra de sigilo telefônico dos envolvidos, entre eles, o paciente. No curso das investigações, detectada a prática transnacional do delito, o juiz estadual declinou da competência para a Justiça Federal, entendendo-se lícita, então, a prova colhida.

Cesar Dario Mariano da Silva também se posiciona nesse sentido, mas enfatiza que "assim que as informações aparecerem, caberá ao Órgão Ministerial ou à Autoridade Policial comunicar o fato ao Juiz que determinou a interceptação (...)”."288

\footnotetext{
287 BRASIL. Supremo Tribunal Federal. 1a Turma. Habeas Corpus 99.619/RJ. Relator Ministro Marco Aurélio. Relatora p/ Acórdão Ministra Rosa Weber. Julgado em 14/02/2012. DJe 59, divulgado em 21/03/2012, publicado em 22/03/2012. Acórdão disponível em: <http://redir.stf.jus.br/paginadorpub/paginador.jsp?docTP=TP\&docID=1836586 > . Acesso em: 20/08/2012.

${ }^{288}$ Provas ilícitas... op.cit., p.41.
} 
Aliás, não é só a competência dentro da mesma instância que suscita problemas quanto aos conhecimentos obtidos durante a investigação e dela decorrentes. É que durante o monitoramento telefônico, também pode ser descoberta a participação de terceiro que altera a competência do juiz que autorizou a diligência.

Lembre-se: ainda que determinada por juiz competente, e em que pese a diligência investigatória seja realizada nos estritos limites em que deferida, pode ser que no decorrer da interceptação telefônica judicialmente autorizada sejam incriminadas outras pessoas, identificadas somente após o início do procedimento. De fato, o monitoramento telefônico pode revelar conversas que levem ao conhecimento de outro participante do delito investigado, sendo o material probatório recolhido apto a ser levado em consideração pelo julgador para a condenação também deste criminoso. É que se trata de conhecimento que há de ser imputado à própria investigação (segundo o conceito adotado no capítulo anterior), pois o terceiro, até então ignorado, é que surge como coautor do crime investigado que fundamentou o recurso ao meio de obtenção de prova em curso, numa relação de concurso de agente com o alvo da medida.

E como alerta CESAR DARIO MARIANO DA Silva, a situação pode complicar quando durante o procedimento da interceptação telefônica surgir prova da participação no delito de alguém que detenha prerrogativa de foro em virtude de suas funções. Consoante o autor, "nesse caso, a partir do momento em que essa situação for verificada, os autos deverão ser imediatamente encaminhados para a autoridade judiciária competente”. Caso não haja o encaminhamento e seja dada sequência à interceptação, inclusive com prorrogações da medida, "a prova, no que diz respeito à pessoa com prerrogativa de foro, será nula de forma absoluta, nos termos do art.564, I, primeira parte, do Código de Processo Penal, uma vez que produzida por Juiz absolutamente incompetente". ${ }^{289}$

Há no STF precedente que trata exatamente dessa hipótese, ou seja, de autorização para interceptação telefônica emanada por juiz no curso de investigação criminal, no âmbito da qual surgiram informações sobre o envolvimento no delito de pessoas detentoras de prerrogativa de foro em virtude de suas funções - no caso, magistrados paulistas. Trata-se do HC 84.388, assim ementado no tópico pertinente ao tema:

${ }^{289}$ Provas ilícitas... op.cit., p.41. 
INCOMPETÊNCIA DA JUSTIÇA FEDERAL DE ALAGOAS PARA AUTORIZAR A REALIZAÇÃO DAS ESCUTAS TELEFÔNICAS QUE ENVOLVEM MAGISTRADOS PAULISTAS. As investigações foram iniciadas na Justiça Federal de Alagoas em razão das suspeitas de envolvimento de policiais federais em atividades criminosas. Diante da descoberta de possível envolvimento de magistrados paulistas, o procedimento investigatório foi imediatamente encaminhado ao Tribunal Regional Federal da $3^{\mathrm{a}}$ Região, onde as investigações tiveram prosseguimento, com o aproveitamento das provas até então produzidas. $^{290}$

Thiago André Pierobom de Ávila também imaginou a situação em debate, chegando à mesma conclusão, no sentido de que nesses casos (hipótese de um juiz autorizar a interceptação telefônica de $A$ e, posteriormente, descobre-se que $B$, portador de foro por prerrogativa de função, é coautor do delito), "é necessária a comunicação posterior dos fatos ao juiz para que ele decida sobre sua competência de autorizar as novas diligências". ${ }^{291}$ E complementa:

\footnotetext{
Quando se documentar que as novas circunstâncias alteram a competência do juiz para autorizar a restrição haverá a necessidade de uma nova representação policial esclarecendo o andamento das investigações, manifestação do Ministério Público e uma decisão do juiz encaminhando o feito ao outro juízo competente para nova autorização de continuidade das diligências. ${ }^{292}$
}

De fato, a partir do momento em que o monitoramento telefônico revele diálogos que coloquem pessoa detentora de foro privilegiado na condição de suspeito do crime investigado, impõe-se, desde logo, o compulsório deslocamento da investigação, sob pena de comprometimento da garantia constitucional do juiz natural (art.5 $5^{\circ}$, inc. LIII, CF), pois a imponderabilidade pressuposta na decisão originária acaba no momento em que os relatórios de inteligência indicam a participação nos fatos de pessoas que deveriam ser submetidas a juízos naturais diversos.

\footnotetext{
${ }^{290}$ Habeas Corpus $84.388 / S P$... cit. (sem grifos no original).

${ }^{291}$ Provas ilícitas e proporcionalidade... op.cit., p. 221.

292 Ibid., p. 222.
} 


\section{CONCLUSÃO}

Não obstante os posicionamentos já emitidos ao longo do trabalho, o encerramento do estudo efetuado sobre o tema deve vir acompanhado da exposição das seguintes considerações, essenciais para uma análise conclusiva:

A partir da definição de meios de obtenção de prova, é possível identificá-los como instrumentos que geram restrições a direitos fundamentais pessoais consagrados constitucionalmente, avançando sobre a reserva da intimidade e da vida privada. Aí se enquadram, por exemplo, as medidas de busca e apreensão e a interceptação das comunicações telefônicas.

Mas, só se justificam restrições a direitos individuais, em face da Constituição, por razões de necessidade, adequação e supremacia do valor a ser protegido em confronto com aquele a ser restringido (proporcionalidade em sentido estrito). Não se trata de uma ponderação abstrata e genérica, mas de uma verificação do justo equilíbrio em cada caso dos valores em conflito.

Daí a necessidade de que uma medida restritiva a direito individual só possa ser autorizada por meio de uma decisão judicial circunstanciada. Extraída a regra da reserva de jurisdição, toma-se em consideração o princípio da especialidade da prova, que impõe que a limitação a direitos fundamentais para fins de obtenção de prova criminal deve respeitar a intimidade e a privacidade naquilo que não foi objeto específico da autorização judicial.

Nesse contexto é que a pesquisa desenvolvida teve por objeto o estudo dos conhecimentos obtidos de forma fortuita, no curso da realização legal de um meio de obtenção de prova autorizado judicialmente, que não se reportam ao crime objeto de investigação e legitimador da medida restritiva.

Embora o tema dos conhecimentos fortuitos, sob o rigor do princípio da especialidade, esteja inserido no estudo da regra da inadmissibilidade das provas ilícitas, no que se refere à inobservância da necessária vinculação causal que a prova deve guardar quando se está diante de uma medida que restringe direitos fundamentais, notou-se uma preocupação no sentido de reconhecer a licitude das provas fortuitamente alcançadas.

De fato, apesar da constatação de que o ordenamento jurídico brasileiro não dispõe de qualquer referência legislativa acerca da problemática, na doutrina, observou-se 
que é minoritária a recusa peremptória da licitude dos conhecimentos fortuitos, sendo dominante, pelo contrário, o entendimento por sua admissibilidade, contando com a exigência mínima de conexão entre o crime casualmente descoberto e aquele objeto de investigação.

A pesquisa jurisprudencial também sinalizou, a partir da análise dos precedentes citados no corpo do trabalho, para a admissibilidade dos conhecimentos fortuitos, por vezes também sugerindo que a conexão entre os crimes justificaria a licitude e o aproveitamento da prova.

O presente estudo, tendo como foco principal a interceptação das comunicações telefônicas e a busca domiciliar, possibilitou que se passasse a concordar com o critério que permite que a prova obtida a partir do desvio causal seja admitida no processo, desde que se refira a um crime relacionado com o fato investigado que ensejou, originariamente, a quebra do sigilo ou afastou a inviolabilidade domiciliar. O grau deste relacionamento, como limite de tal critério, concretiza-se na leitura restritiva das regras de definição da competência por conexão e continência previstas na legislação processual penal.

A crítica que se fez a esse critério como solução ao problema se deu no âmbito do tratamento processual diferenciado a ser imposto a uma mesma figura - a dos conhecimentos fortuitos -, de modo que, os elementos de prova obtidos através de uma medida excepcional poderão ingressar no processo quando o conhecimento obtido fortuitamente revelar crime que contém uma relação de conexão ou continência com o crime objeto da investigação (prova idônea à valoração judicial), mas não quando revelar fato totalmente independente do delito investigado.

Por isso, contando com as contribuições da doutrina estrangeira para a solução do problema proposto, permitiu-se ir além, adotando o critério que diferencia conhecimentos fortuitos dos conhecimentos da investigação. De modo que, operada a cisão, consoante a classificação dada aos conhecimentos obtidos, dependerá o tratamento processual a dispensar quanto à admissibilidade no processo da prova obtida e sua valoração como elemento apto à demonstração do delito casualmente descoberto, ou sua eventual utilização como mera notícia de crime.

Destarte, concluiu-se pela necessidade de se delimitar a fronteira entre os conhecimentos imputados à própria investigação e aqueles que, inversamente e 
residualmente, se levam em conta de conhecimentos fortuitos, socorrendo-se para tanto de um critério objetivo que consolide essa distinção.

Identificou-se, no ordenamento pátrio, que as normas positivas suscetíveis de preencher o conceito que distancia os conhecimentos fortuitos dos conhecimentos da instigação, concretizando a ideia de unidade processual investigatória que vai demarcar a fronteira entre os dois institutos, são aquelas insculpidas nos artigos 76 e 77 do Código de Processo Penal brasileiro, que ditam as regras de conexão e continência, sendo que tais hipóteses não restam abrangidas em outro universo senão o dos conhecimentos da investigação, e como tais, sequer serão considerados encontros fortuitos.

A objetividade do critério, com assento legal, garante a segurança jurídica necessária para a delimitação conceitual, afinal, aproveitando-se das regras de conexão e continência, a limitação que se propõe está embasada no sentido de que apenas os conhecimentos da investigação surtirão efeitos probatórios, já que os elementos de prova recolhidos integrarão o mesmo processo no âmbito do qual foi autorizada a medida de interceptação telefônica ou de busca e apreensão.

Em contrapartida, os conhecimentos que não apresentem identidade investigatória com o crime legitimador da medida restritiva hão de ser tidos como fortuitos, aos quais se atribui apenas uma relevância investigatória, servindo como mera notícia de crime conformadora de indício para o início de nova investigação, no âmbito da qual novas medidas restritivas eventualmente poderão ser autorizadas, dentro dos limites legais, sempre com exigência de prévia autorização judicial motivada, pautada pelo princípio da proporcionalidade.

Eis as conclusões a que se chega, e que refletem uma tomada de posição, ainda que talvez provisória, a partir do momento em que contribuem para o fomento da discussão do tema envolvendo os conhecimentos fortuitos no processo penal brasileiro, questão complexa nem sempre debatida, quer pela doutrina, pela jurisprudência, ou pelo Poder Legislativo, diferente do que se observou no direito comparado. 


\section{REFERÊNCIAS}

AGUILAR, Francisco. Dos conhecimentos fortuitos obtidos através de escutas telefónicas: contributo para o seu estudo nos ordenamentos jurídicos alemão e português. Coimbra: Almedina, 2004.

ALMEIDA, José Raul Gavião de. Anotações acerca do direito à privacidade. In: MIRANDA, Jorge; SILVA, Marco Antonio Marques da (Coord.). Tratado Luso-Brasileiro da Dignidade Humana. 2.ed. São Paulo: Quartier Latin, 2009. p.719-726.

ANDRADE, Manuel da Costa. Sobre as Proibições de Prova em Processo Penal. Coimbra: Coimbra Editora, 2006. Reimpressão da obra de 1992.

ARANHA, Adalberto José Q. T. de Camargo. Da prova no processo penal. 7.ed. São Paulo: Saraiva, 2006.

ÁVILA, Thiago André Pierobom de. Provas ilícitas e proporcionalidade: uma análise da colisão entre os princípios da proteção penal eficiente e da inadmissibilidade das provas obtidas por meios ilícitos. Dissertação (Mestrado). Faculdade de Direito da Universidade de Brasília, 2006. Disponível em: $<$ http://repositorio.bce.unb.br/bitstream/10482/3103/1/Disserta\%C3\%A7\%C3\%A3o\%20\% 20THIAGO\%20ANDR\%C3\%89\%20PIEROBOM\%20DE\%20\%C3\%81VILA\%20Provas\%20I1\%C3\%ADcitas.pdf >. Acesso em: 15/04/2012.

AVOLIO, Luiz Francisco Torquato. Provas ilícitas: interceptações telefônicas, ambientais e gravações clandestinas. 4.ed. São Paulo: Revista dos Tribunais, 2010.

BADARÓ, Gustavo Henrique Righi Ivahy. Direito Processual Penal. Tomo I. Rio de Janeiro: Elsevier, 2008.

BECHARA, Fábio Ramazzini; DEZEM, Guilherme Madeira. Captação ambiental de imagens: uso e limites. In: Estudos de processo penal. INSTITUTO DE ESTUDOS AVANÇADOS DE PROCESSO PENAL - ASF. São Paulo: Scortecci, 2011. p.116-140. Disponível em: <http://www.institutoasf.com.br/dcms/uploads/arquivo_07112011003518.pdf>. Acesso em: $12 / 10 / 2012$.

BELLOQUE, Juliana Garcia. Sigilo bancário: análise crítica da LC 105/2001. São Paulo: Revista dos Tribunais, 2003.

BRASIL. Conselho Nacional de Justiça. Notícias. Brasil teve 20 mil linhas telefônicas monitoradas em 2010. Disponível em: <http://www.cnj.jus.br/noticias/10671:brasil-teve20-mil-linhas-telefonicas-monitoradas-em-2010>. Acesso em: 15/04/2012. 
. Conselho Nacional de Justiça. Notícias. Mais de 18 mil telefones monitorados em outubro de 2011. Disponível em: <http://www.cnj.jus.br/noticias/cnj/17795-justicaautoriza-grampo-em-195-mil-telefones-em-2011>. Acesso em: 15/04/2012.

. Instituto Brasileiro de Direito Processual (IBDP). Comissão de membros do IBDP. Propostas de emendas ao Projeto de Lei de Código de Processo Penal Substitutivo CCJ do Senado. Relator: Presidência de Ada Pellegrini Grinover. Disponível em: $\quad\langle$ http://www.novo.direitoprocessual.org.br/content/blocos/96/1 > . Acesso em: 20/08/2010.

. Senado Federal. Comissão de juristas responsável pela elaboração de anteprojeto de reforma do Código de Processo Penal. Anteprojeto. Brasília: Senado Federal, 2009. Disponível em: 〈http://legis.senado.gov.br/mate-pdf/58503.pdf>. Acesso em: 16/08/2010.

Disponível

Senado Federal. Redação final do Projeto de Lei do Senado $n^{o}$ 156/2009.

$\langle$ http./Www senado gov br/atividade/materia/getPDF asp?t=85509\&tp=1>. Acesso em: $14 / 12 / 2010$.

Senado Federal. Substitutivo CCJ ao Projeto de Lei do Senado $n^{o}$ 156/2009. Disponível em: 〈http://legis.senado.gov.br/mate-pdf/74697.pdf>. Acesso em: 16/08/2010.

Superior Tribunal Justiça. $5^{\mathrm{a}}$ Turma. Habeas Corpus 151.530/PB. Relatora Ministra Laurita Vaz. Julgado em 18/05/2010, DJe 14/06/2010. Acórdão disponível em: $<$ https://ww2.stj.jus.br/revistaeletronica/Abre_Documento.asp?sSeq=972154\&sReg=2009 02083349\&sData=20100614\&formato=PDF>. Acesso em: 09/07/2011.

- Superior Tribunal Justiça. $5^{\mathrm{a}}$ Turma. Habeas Corpus 33.462/DF. Relatora Ministra Laurita Vaz. Julgado em 27/09/2005. DJ 07/11/2005, p. 316. Acórdão disponível em:

<https://ww2.stj.jus.br/revistaeletronica/Abre_Documento.asp?sSeq=582592\&sReg=2004 00136129\&sData=20051107\&formato=PDF>. Acesso em: 13/07/2011.

. Superior Tribunal Justiça. $5^{\mathrm{a}}$ Turma. Habeas Corpus 33.553/CE. Relatora Ministra Laurita Vaz. Julgado em 17/03/2005. DJ 11/04/2005, p.338. Acórdão disponível em:

<https://ww2.stj.jus.br/revistaeletronica/Abre_Documento.asp?sSeq=534863\&sReg=2004 00152006\&sData=20050411\&formato=PDF>. Acesso em: 09/07/2011.

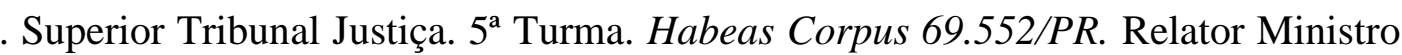
Felix Fischer. Julgado em 06/02/2007. DJ 14/05/2007, p.347. Acórdão disponível em: <https://ww2.stj.jus.br/revistaeletronica/Abre Documento.asp?sSeq=671032\&sReg=2006 02419935\&sData=20070514\&formato=PDF>. Acesso em: 09/07/2011.

. Superior Tribunal Justiça. $5^{\mathrm{a}}$ Turma. Habeas Corpus 83.632/SP. Relator Ministro Jorge Mussi. Julgado em 19/08/2010, DJe 20/09/2010. Acórdão disponível em: 
$<$ https://ww2.stj.jus.br/revistaeletronica/Abre_Documento.asp?sSeq=996036\&sReg=2007 01201332\&sData=20100920\&formato=PDF>. Acesso em: 09/07/2011.

Superior Tribunal Justiça. Corte Especial. Ação Penal 425/ES. Relator Ministro José Arnaldo da Fonseca. Julgado em 16/11/2005. DJ 15/05/2006, p. 141. Acórdão disponível em: <https://ww2.stj.jus.br/revistaeletronica/Abre_Documento.asp?sSeq=593161\&sReg=2005

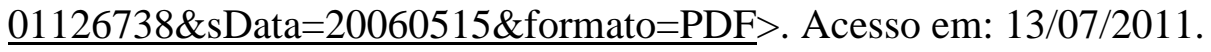

Supremo Tribunal Federal. $1^{\mathrm{a}}$ Turma. Habeas Corpus 78.098/SC. Relator Ministro Moreira Alves. Julgado em 01/12/1998. DJ 06/08/1999. Acórdão disponível em: $<$ http://redir.stf.jus.br/paginadorpub/paginador.jsp?docTP=AC\&docID=77742>. Acesso em: 13/07/2011.

. Supremo Tribunal Federal. $1^{\text {a }}$ Turma. Habeas Corpus 99.619/RJ. Relator Ministro Marco Aurélio. Relatora p/ Acórdão Ministra Rosa Weber. Julgado em 14/02/2012. DJe 59, divulgado em 21/03/2012, publicado em 22/03/2012. Acórdão disponível em: $<$ http://redir.stf.jus.br/paginadorpub/paginador.jsp?docTP=TP\&docID=1836586 >. Acesso em: 20/08/2012.

Supremo Tribunal Federal. $2^{\mathrm{a}}$ Turma. Agravo Regimental em Agravo de Instrumento 626.214/MG. Relator Ministro Joaquim Barbosa. Julgado em 21/09/2010. DJe-190, divulgado em 07/10/2010, publicado em 08/10/2010. Acórdão disponível em: $\langle$ http://redir.stf.jus.br/paginadorpub/paginador.jsp?docTP=AC\&docID=615361>. Acesso em: 09/07/2011.

. Supremo Tribunal Federal. $2^{\mathrm{a}}$ Turma. Habeas Corpus 84.388/SP. Relator Ministro Joaquim Barbosa. Julgado em 26/10/2004. DJ 19/05/2006, p.42. Acórdão disponível em: $\langle$ http://redir.stf.jus.br/paginadorpub/paginador.jsp?docTP=AC\&docID=79578>. Acesso em: 09/07/2011.

Supremo Tribunal Federal. Plenário. Ação Penal 307-3/DF. Relator Ministro Ilmar Galvão. Julgado em 13/12/1994. DJ 13/10/1995, p.34247. Acórdão disponível em: $<$ http://redir.stf.jus.br/paginadorpub/paginador.jsp?docTP=AC\&docID=324295>. Acesso em: 09/07/2011.

Supremo Tribunal Federal. Tribunal Pleno. Habeas Corpus 81.260/ES. Relator Ministro Sepúlveda Pertence. Julgado em 14/11/2001. DJ 19/04/2002, p.48. Acórdão disponível em: $<$ http://redir.stf.jus.br/paginadorpub/paginador.jsp?docTP=AC\&docID=78672>. Acesso em: 13/07/2011.

. Supremo Tribunal Federal. Tribunal Pleno. Habeas Corpus 83.515/RS. Relator Ministro Nelson Jobim. Julgado em 16/09/2004. DJ 04/03/2005, p.11. Acórdão disponível em: $\quad\langle$ http://redir.stf.jus.br/paginadorpub/paginador.jsp?docTP=AC\&docID=79377>. Acesso em: 09/07/2011. 
Supremo Tribunal Federal. Tribunal Pleno. Habeas Corpus 95.009/SP. Relator Ministro Eros Grau. Julgado em 06/11/2008. DJe 241, divulgado em 18/12/2008, publicado em 19/12/2008. Acórdão disponível em: $<$ http://redir.stf.jus.br/paginadorpub/paginador.jsp?docTP=AC\&docID=570249 $>$. Acesso em: 09/07/2011.

. Tribunal de Justiça de São Paulo. $6^{a}$ Câmara Criminal. Apelação Criminal $n^{o}$ 993.07.104484-9. Relator Desembargador José Raul Gavião de Almeida. Julgado em 11/03/2010. Acórdão disponível em: $<$ https://esaj.tjsp.jus.br/cjsg/getArquivo.do?cdAcordao=4384048 $>. \quad$ Acesso em: 09/07/2011.

Tribunal de Justiça de São Paulo. 6a Câmara Criminal. Apelação Criminal $n^{o}$ 990.09.160391-0. Relator Desembargador José Raul Gavião de Almeida. Julgado em 21/10/2010. Acórdão disponível em: $\langle$ https://esaj.tjsp.jus.br/cjsg/getArquivo.do?cdAcordao=4779551>. Acesso em: 09/07/2011.

. Tribunal de Justiça de São Paulo. 6 Câmara Criminal. Mandado de Segurança $n^{o}$ 990.09.070761-5. Relator Desembargador José Raul Gavião de Almeida. Julgado em 26/11/2009. Acórdão disponível em: $\langle$ https://esaj.tjsp.jus.br/cjsg/getArquivo.do?cdAcordao=4228555>. Acesso em: $09 / 07 / 2011$.

. Tribunal Regional Federal da $2^{\mathrm{a}}$ Região. $1^{\mathrm{a}}$ Turma especializada. Habeas Corpus 2007.02.01.016145-6. Relator Desembargador Federal Abel Gomes. Julgado em 23/07/2008. DJU 13/08/2008, p.64. Acórdão disponível em: <http://www.trf2.gov.br/cgibin/pdbi?PRO=200702010161456\&TOPERA=1\&I1=OK>. Acesso em: 15/04/2012.

. Tribunal Regional Federal da $4^{\mathrm{a}}$ Região. $4^{\mathrm{a}}$ Turma. Agravo de Instrumento 0011686-54.2011.404.0000. Relator Des. Federal Luís Alberto D'Azevedo Aurvalle. Julgado em 24/04/2012. D.E. divulgado em 27/04/2012, publicado em 30/04/2012. Acórdão disponível

em: $<$ http://jurisprudencia.trf4.jus.br/pesquisa/inteiro_teor.php?orgao $=1 \&$ documento $=4699505$ $>$. Acesso em: 20/08/2012.

. Tribunal Regional Federal da $4^{\mathrm{a}}$ Região. $7^{\mathrm{a}}$ Turma. Apelação Criminal 2003.70.00.019106-4. Relator Desembargador Federal Néfi Cordeiro. Julgado em 21/09/2010. D.E. divulgado em 30/09/2010, publicado em 01/10/2010. Acórdão disponível em:

$<$ http://jurisprudencia.trf4.jus.br/pesquisa/inteiro_teor.php?orgao $=1 \&$ documento $=3362118$ $>$. Acesso em: 15/04/2012

CANOTILHO. José Joaquim Gomes. Direito Constitucional e Teoria da Constituição. 3.ed. Almedina, 1999. 
CARBONE, Carlos Alberto. Requisitos constitucionales de las intervenciones telefónicas: correspondencia telefónica, informática y audiovisual intervenida judicialmente en el proceso penal. Santa Fe: Rubinzal-Culzoni, 2008.

CARVAlHO, Luis Gustavo Grandinetti Castanho de. Processo Penal e (em face da) Constituição. 3.ed. Rio de Janeiro: Lumens Juris, 2004.

CERNICCHIARO, Luiz Vicente. Lei 9.296/96: interceptação telefônica. In: Boletim IBCCRIM. São Paulo, no 47, p. 03, out./1996.

DEZEM, Guilherme Madeira. Da prova penal: tipo processual, provas típicas e atípicas. Campinas: Millennium, 2008.

ECHARRI CASI, Fermín Javier. Prueba ilícita: conexión de antijuridicidad y hallazgos casuales. In: Revista del Poder Judicial. Madrid, nº 69, p.261-301, 2003.

ESPANHA. Ley de Enjuiciamiento Criminal. Disponível em: $<$ http://noticias.juridicas.com/base_datos/Penal/lecr.html >. Acesso em: 15/04/2012.

. Tribunal Supremo. Sala de lo Penal. STS 6147/2012. Disponível em: $<$ http://www.poderjudicial.es/search/doAction?action=contentpdf\&databasematch=TS\&ref erence $=6514953 \&$ links $=$ hallazgos $\% 20 \mathrm{y} \% 20$ casuales $\% 20 \mathrm{e} \% 20$ telefonica $\&$ optimize $=2012$ 1016\&publicinterface=true $>$. Acesso em: 02/09/2012.

. Tribunal Supremo. Sala de lo Penal. STS 7314/2010. Disponível em: $<$ http://www.poderjudicial.es/search/doAction?action=contentpdf\&databasematch=TS\&ref erence $=5836266 \&$ links $=$ \&optimize $=20110203 \&$ publicinterface $=$ true $>. \quad$ Acesso em: 02/09/2012.

FERNANDES, Antonio Scarance. A lei de interceptação telefônica. In: PENTEADO, Jacques de Camargo (Org.). Justiça penal: críticas e sugestões: provas ilícitas e reforma pontual. v.4. São Paulo: Revista dos Tribunais, 1997. p.48-70

O equilíbrio entre a eficiência e o garantismo e o crime organizado. In: Revista Brasileira de Ciências Criminais. São Paulo, no 70, p.229-268, jan-fev/2008.

O equilíbrio na repressão ao crime organizado. In ; ALMEIDA, José Raul Gavião de; MORAES, Mauricio Zanoide de (Coords.). Crime organizado: aspectos processuais. São Paulo: Revista dos Tribunais, 2009. p.09-28.

Processo Penal Constitucional. 6.ed. São Paulo: Revista dos Tribunais, 2010.

Reflexões sobre as noções de eficiência e de garantismo no processo penal. In:

; ALMEIDA, José Raul Gavião de; MORAES, Mauricio Zanoide de (Coords.). Sigilo no processo penal: eficiência e garantismo. São Paulo: Revista dos Tribunais, 2008. p.9-28. 
FERRAZ JUNIOR, Tércio Sampaio. Sigilo de dados: o direito à privacidade e os limites à função fiscalizadora do Estado. In: Revista da Faculdade de Direito da Universidade de São Paulo. São Paulo, v.88, p.439-459, 1993.

FERREIRA, Aurélio Buarque de Holanda. Novo Dicionário da Língua Portuguesa. 2.ed. Rio de Janeiro: Editora Nova Fronteira, 1986.

FONSECA, Tiago Abud da. Interceptação telefônica: a devassa em nome da lei. Rio de Janeiro: Espaço Jurídico, 2008.

GATTI, Giustino. Codice di procedura penale: annotato con la giurisprudenza. XVIII edizione. Napoli: Edizioni Giuridiche Simone, 2010.

GOMES FILHO, Antonio Magalhães. Direito à Prova no Processo Penal. São Paulo: Revista dos Tribunais, 1997.

. Notas sobre a terminologia da prova (reflexos no processo penal brasileiro). In: YARSHELL, Flávio Luiz; MORAES, Maurício Zanoide de (Org.). Estudos em homenagem à Professora Ada Pellegrini Grinover. São Paulo: DPJ Editora, 2005. p.303318.

Provas - Lei 11.690, de 09.06.2008. In: MOURA, Maria Thereza Rocha de Assis (Coord.). As Reformas no Processo Penal: as novas leis de 2008 e os projetos de reforma. São Paulo: Revista dos Tribunais, 2008. p.246-297.

A violação do princípio da proporcionalidade pela Lei 9296/96. In: Boletim IBCCRIM. São Paulo, nº 45, p.14, agosto/1996.

; BADARÓ, Gustavo Henrique Righi Ivahy. Prova e sucedâneos de prova no processo penal brasileiro. In: Revista Brasileira de Ciências Criminais, São Paulo, $\mathrm{n}^{\circ}$ 65, p.175-208, mar-abril/2007.

GOMES, Luiz Flávio. Interceptação telefônica e encontro fortuito de outros fatos. In: Boletim IBCCRIM. São Paulo, n 51, p. 06, fevereiro/1997.

_. Interceptação telefônica e encontro fortuito: prova (in)válida? Publicado em 24 de agosto de 2010. Disponível em: $<$ http://www.lfg.com.br/public $\mathrm{html} /$ article.php?story=20100824141123304\&mode $=$ print $>$. Acesso em: 03/03/2011.

. Natureza jurídica da serendipidade nas interceptações telefônicas. Publicado em 21 de março de $2009 . \quad$ Disponível em: <http://www.lfg.com.br/public html/article.php?story=20090316100443595\&mode=print >. Acesso em: 04/011/2009.

; CERVINI, Raúl. Interceptação telefônica: Lei 9.296/96 de 24.07.96. São Paulo: Revista dos Tribunais, 1997. 
; DONATI, Patricia. Interceptação telefônica e serendipidade: encontro fortuito de fatos ou agentes novos. Publicado em 08 de abril de 2009. Disponível em $<$ http://www.lfg.com.br/public_html/article.php?story=20090408093130200\&mode=print

>. Acesso em: 03/03/2011.

GRECO FILHO, Vicente. Interceptação telefônica: considerações sobre a Lei no 9.296, de 24 de julho de 1996. 2.ed. São Paulo: Saraiva, 2008.

GRINOVER, Ada Pellegrini. Do regime das interceptações telefônicas no projeto de novo CPP - proposta de emendas do IBDP. In: Boletim IBCCrim. São Paulo, ed. especial CPP, p.2-3, agosto/2010.

. Liberdades públicas e processo penal: as interceptações telefônicas. São Paulo: Saraiva, 1976.

1990.

. Novas tendências do direito processual. Rio de Janeiro: Forense Universitária,

Novo anteprojeto de lei que disciplina a quebra de sigilo das comunicações telefônicas. In: Revista Literária de Direito. São Paulo, ano 9, nº 47, p.19-21, jun-jul/2003.

. O sistema de nulidades processuais e a Constituição. In: TUBENCHLAK, James; BUSTAMANTE, Ricardo (Org.). Livro de Estudos Jurídicos. v.6. Rio de Janeiro: Instituto de Estudos Jurídicos, 1993. p.156-168.

; FERNANDES, Antonio Scarance; GOMES FILHO, Antonio Magalhães. As nulidades no processo penal. 11.ed. São Paulo: Revista dos Tribunais, 2009.

HASSEMER, Winfried. Processo Penal e direitos fundamentais. Transcrição da intervenção oral pelo Goethe-Institut Lissabon; tradução da conferência para língua portuguesa por Augusto Silva Dias. In: Jornadas de Direito Processual Penal e Direitos Fundamentais. Organização Faculdade de Direito de Lisboa e Conselho Distrital de Lisboa da Ordem dos Advogados. Coordenação científica de Maria Fernanda Palma. Coimbra: Almedina, 2004. p.15-25.

JESUS, Damásio Evangelista de. Interceptação de comunicações telefônicas: notas à Lei 9.296, de 24.07.1996. In: Revista dos Tribunais, São Paulo, nº 735, p.458-473, jan/1997.

LATTANZI, Giorgio. Codice di procedura penale: rassegna di giurisprudenza e di dottrina. Libri II e III. Milano: Giuffrè Editore, 1997.

LEITE, Larissa. Medidas patrimoniais de urgência no processo penal: implicações teóricas e práticas. Rio de Janeiro: Renovar, 2011.

LIMA, Monica Isabel Fonseca Sequeira. Conhecimentos fortuitos nas escutas telefónicas: razão de ser dos crimes de catálogo. Lisboa, 06 de fevereiro de 2011. Disponível em 
<http://pt.scribd.com/doc/49381612/Conhecimentos-Fortuitos-nas-Escutas-TelefonicasRazao-de-ser-dos-crimes-de-catalogo>. Acesso em: 14/06/2011.

LOPES JUNIOR, Aury. Direito Processual Penal e sua Conformidade Constitucional. v.1. 5.ed. Rio de Janeiro: Lumen Juris, 2010.

LOPES, Fábio Motta. O encontro fortuito de provas durante buscas domiciliares. In: Boletim IBCCRIM, São Paulo, nº 220, p. 14-15, março/2011.

LOPES, Mariângela Tomé. A infiltração de agentes no Brasil e na Espanha: possibilidade de reformulação do sistema brasileiro com base no direito espanhol. In: Revista Brasileira de Ciências Criminais, São Paulo, no 89. p.495-532, mar.-abr./2011.

LÓPEZ FRAGOSO, Tomás. Los descubrimientos casuales en las intervenciones telefónicas como medidas coercitivas en el proceso penal. In: Derechos y Libertades: Revista del Instituto Bartolomé de Las Casas. Madrid, nº 02, p.81-89, out/93 a mar/94.

MACHADO, Andre Augusto Mendes; KEHDI, Andre Pires de Andrade. Sigilo das comunicações e de dados. In: FERNANDES, Antonio Scarance; ALMEIDA, José Raul Gavião de; MORAES, Mauricio Zanoide de (Coords.). Sigilo no processo penal: eficiência e garantismo. São Paulo: Revista dos Tribunais, 2008. p.239-266.

MARQUES, José Frederico. Elementos de Direito Processual Penal. v. I. Campinas: Bookseller, 1997.

MORAES, Alexandre de. Direitos humanos fundamentais: teoria geral, comentários aos arts. $1^{\circ}$ a $5^{\circ}$ da Constituição da República Federativa do Brasil, doutrina e jurisprudência. São Paulo: Atlas, 1998.

MORAES, Maurício Zanoide de. Entre Prometeu e Cassandra, o IBCCRIM continua como bastião mais altivo e lúcido contra as violações constitucionais. In: Boletim IBCCRIM. São Paulo, ed. especial 20 anos, p.05-06, agosto/2012.

MORO, Sergio Fernando. Crime de lavagem de dinheiro. São Paulo: Saraiva, 2010.

OLIVEIRA, Eugenio Pacelli de. Curso de Processo Penal. 10.ed. Rio de Janeiro: Lúmen Júris, 2008.

PITOMBO, Cleunice A. Valentim Bastos. Da busca e da apreensão no processo penal. 2.ed. São Paulo: Revista dos Tribunais, 2005.

. Licitude da prova obtida por meio da busca e da apreensão. In: VILARDI, Celso Sanchez; BRESSER, Flavia Rahal; DIAS NETO, Theodomiro (Coord.). Direito penal econômico: crimes econômicos e processo penal. Série GV law. São Paulo: Saraiva, 2008. p.51-96. 
PITOMBO, Sérgio Marcos de Moraes. Sigilo nas comunicações: aspecto processual penal. In: Boletim IBCCRIM. São Paulo, nº 49, p. 07-08, dezembro/1996.

PORTUGAL. Codigo de Processo Penal. Disponível em $<$ http://www.pgdlisboa.pt/pgdl/leis/lei_print_articulado.php?tabela=leis\&artigo_id=\&nid= $199 \&$ nversao=\&tabela=leis $>$. Acesso em: 02/07/2011.
Constituição da República Portuguesa. Disponível em $\langle$ http://www.parlamento.pt/Legislacao/Paginas/ConstituicaoRepublicaPortuguesa.aspx $>$. Acesso em: 02/07/2011.

PRADO, Geraldo. Limite às interceptações telefônicas e a Jurisprudência do Superior Tribunal de Justiça. 2.ed. Rio de Janeiro: Lúmen Júris, 2006.

Limite às interceptações telefônicas: a jurisprudência do Superior Tribunal de Justiça no Brasil e a alteração introduzida no Código de Processo Penal Português (Lei $\mathrm{n}^{\circ}$ 48/2007). In: CARVALHO, Luis Gustavo Grandinetti Castanho de (Org). Processo Penal do Brasil e de Portugal: estudo comparado: as reformas portuguesa e brasileira. Coimbra: Almedina, 2009. p.95-146.

RANGEL, Paulo. Breves considerações sobre a Lei $n^{\circ}$ 9.296/96: interceptação telefônica. In: Revista Brasileira de Ciências Criminais, São Paulo, nº 26, p.143-151. abr-jun/1999.

RODRIGUES, Benjamim Silva. Das escutas telefônicas. Tomo I. Coimbra: Coimbra Editora, 2008.

ROXIN, Claus. Derecho procesal penal. Tradução de Gabriela E. Córdoba e Daniel R. Pastor. Buenos Aires: Editores Del Puerto, 2003.

SANTORO, Antonio; SANTOS, Rodolfo. A validade dos conhecimentos fortuitos obtidos nas interceptações telefônicas. In: Boletim IBCCrim. São Paulo, $\mathrm{n}^{\circ}$ 210, p.15-16, maio/2010.

SANTOS, Inês Moreira. Direito fundamental à privacidade vs. persecução criminal: a problemática das escutas telefônicas. In: MIRANDA, Jorge; SILVA, Marco Antonio Marques da (Coord.). Tratado Luso-Brasileiro da Dignidade Humana. 2.ed. São Paulo: Quartier Latin, 2009. p.103-126.

SERRANO MAÍlLO, Alfonso. Valor de las escuchas telefónicas como prueba en el sistema español. Nulidad de la prueba obtenida ilegalmente. In: Revista Brasileira de Ciências Criminais, São Paulo, no 15, p.13-21, jul-set/1996.

SILVA JUNIOR, Walter Nunes da. Curso de Direito Processual Penal: teoria (constitucional) do processo penal. Rio de Janeiro: Renovar, 2008. 
SILVA, Cesar Dario Mariano da. Provas ilícitas: princípio da proporcionalidade, interceptação e gravação telefônica, busca e apreensão, sigilo e segredo, confissão, comissão parlamentar de inquérito (CPI) e sigilo. 6.ed. São Paulo: Atlas, 2010.

SILVA, De Plácido e. Vocabulário Jurídico. 15.ed. Rio de Janeiro: Forense, 1998.

SILVA, Eduardo Araújo da. Crime organizado: procedimento probatório. São Paulo: Atlas, 2003.

SILVA, Germano Maques da. Curso de Processo Penal. v. II. 2.ed. Verbo, 1999.

. Notas sobre as Alterações de 2007 ao Código de Processo Penal Português. In: Carvalho, Luis Gustavo Grandinetti Castanho de (Org). Processo Penal do Brasil e de Portugal: estudo comparado: as reformas portuguesa e brasileira. Coimbra: Almedina, 2009. p.71-93.

SOBRINHO, Mario Sergio. O crime organizado no Brasil. In: FERNANDES, Antonio Scarance; ALMEIDA, José Raul Gavião de; MORAES, Mauricio Zanoide de (Coords.). Crime organizado: aspectos processuais. São Paulo: Revista dos Tribunais, 2009. p.29-54

STRECK, Lenio Luiz. As interceptações telefônicas e os Direitos Fundamentais. Porto Alegre: Livraria do Advogado, 2001.

TAPIA, Juan Francisco. Descubrimientos accidentales en el curso de un registro domiciliario o una intervención de comunicaciones. El problema de los hallazgos casuales o "causales"? In: Revista de Derecho Penal. Buenos Aires, no 2, p.669-684, 2002.

TONINI, Paolo. A prova no processo penal italiano. Tradução de Alexandra Martins e Daniela Mróz. São Paulo: Revista dos Tribunais, 2002.

TOURINHO FILHO, Fernando da Costa. Processo Penal. v.2. 18.ed. São Paulo: Saraiva, 1997.

TRIBUNAL EUROPEU DOS DIREITOS DO HOMEM (TEDH). Caso PRADO BUGALLO c. ESPANHA, acórdão de 18 de Fevereiro de 2003. In: PORTUGAL. Procuradoria-Geral da República. Agente do Governo Português junto do Tribunal Europeu dos Direitos do Homem. Gabinete de Documentação e Direito Comparado. Sumários de Jurisprudência 2003, p.41. Disponível em <http://www.gddc.pt/direitoshumanos/sist-europeu-dh/Sum\%E1rios\%202003.pdf >. Acesso em: 15/04/2012.

VALENTE, Manuel Monteiro Guedes. Conhecimentos fortuitos: a busca de um equilíbrio apuleiano. Coimbra: Almedina, 2006.

. Escutas telefônicas: da excepcionalidade à vulgaridade. Coimbra: Almedina, 
VIEIRA, Renato Stanziola. Agente infiltrado - um estudo comparativo dos sistemas processuais penais português e brasileiro (ou a imprescindibilidade da tipicidade processual como requisito da admissibilidade dos meios de pesquisa de prova em processo penal. In: Revista Brasileira de Ciências Criminais, São Paulo, nº 87, p.188-231, nov.dez./2010. 